\title{
What Is Eleventh Amendment Immunity?
}

\author{
Carlos Manuel Vázquez ${ }^{\dagger}$
}

\section{CONTENTS}

I. THE COMPETING INTERPRETATIONS OF THE ELEVENTH AMENDMENT . . . . . . . . . . . . . . . . . . . . 1693
A. The Rise and Fall of the Diversity Interpretation of the Eleventh Amendment . . . . . . . . . . . . . . . . . . . . 1694

B. The Forum-Allocation and Immunity-from-Liability Interpretations . . . . . . . . . . . . . . . 1700

C. The Relationship Between the Immunity-from-Liability Interpretation of the Eleventh Amendment and the Court's Tenth Amendment Jurisprudence . . . . . . . . . . . . . . . . 1703

II. PRE-SEMINOLE TRIBE SUPPORT FOR READING THE ELEVENTH AMENDMENT AS MERELY A FORUM-ALLOCATION PRINCIPLE . . . 1708
A. Cases Recognizing a Constitutional Obligation of States 10 Afford Monetary Relief to Individuals in Their Own Courts . . . . . . 1709

B. Cases Involving Statutes That Impose a Liability on States Without Abrogating Eleventh Amendment Immunity ......... 1712

III. SEMINOLE TRIBE AND THE CASE FOR AN IMMUNITY-FROM-LIABILITY INTERPRETATION OF THE ELEVENTH AMENDMENT . . . . . . 1714

A. Indications in Seminole Tribe of a Shift to the Immunity-fromLiability Interpretation . . . . . . . . . . . . . 1717

1. The Seminole Tribe Court's Interpretation of Cohens . . 1718

2. Seminole Tribe's Prescriptions for Antitrust, Bankruptcy, Copyright, and Patent Claims Against the States . . . . . 1720

B. Pre-Seminole Tribe Support for the Immunity-from-Liability Interpretation . . . . . . . . . . . . . . . 1722

1. The Framers' Intent ... . . . . . . . . . . 1722

$\dagger$ Professor of Law, Georgetown University Law Center. I am grateful for comments recerved on an earlier draft from Hope Babcock, Peter Byme. William Eskridge. Steven Goldberg. Michael Gottesman. Vicki Jackson, Richard Lazarus, Daniel Meltzer. Roy Schotland. L. Michael Seıdman. Judıth Shapıro. and Mark Tushnet, and for the research assistance of Patnce Michaud and Marcos Hasbun. 
2. The Continuing Doctrinal Connection Between the Eleventh Amendment and the Protection of State Treasuries . . . . 1726

a. The Edelman Line of Cases and the Prospectivel Retrospective Distinction . . . . . . . . . . . 1727

b. Hess and the Question of What Counts as the State . 1731

3. Additional Support in the Case Law for the Immunity-fromLiability Interpretation . . . . . . . . . . . . . 1732
a. Hans ....................... 1733
b. Poindexter ................... 1735
c. Abrogation Cases .................. 1736
d. Hess Again . . . . . . . . . . . . . . . . . . . . 1738

4. Will ....................... 1740

IV. THE ABROGATION REDUCTIO AND MCKESSON'S UNRAVELING $\ldots 1744$

A. The Abrogation Reductio . . . . . . . . . . . . . . . 1745

B. Avoiding the Reductio by Adjusting Constitutional Doctrine . 1749

C. McKesson and the Abrogation Reductio ........... 1753

1. Avoiding the Reductio by Relying on McKesson and Related Procedural Due Process Cases ............... 1753

2. The Scope of Congress's Section 5 Enforcement Power . . 1760

3. The Untenability of the Conventional Reading of McKesson ..................... 1763

V. REINTERPRETING MCKESSON .............. 1766

A. Reinterpreting McKesson as to the Source of the Obligation to Afford Relief . . . . . . . . . . . . . . . . . . . . . 1767

B. Reinterpreting McKesson as to the Subject of the Duty to Pay Damages . . . . . . . . . . . . . . . . . . . . . . 1771

C. McKesson as a Supremacy Clause Case . . . . . . . . . 1778

VI. THE ELEVENTH AMENDMENT AS IMMUNITY FROM LIABILITY: IMPLICATIONS, OPEN QUESTIONS, AND COMPATIBILITY WITH THE RULE OF LAW . . . . . . . . . . . . . . . . . . 1790

VII. Conclusion: The EleVENTH AMENDMENT and tHE RULE OF LAW . . . . . . . . . . . . . . . . . . . 1805 
The Eleventh Amendment has long been regarded as an embarrassment to the United States's aspiration to be a government of laws and not of men.' This rule-of-law ideal has rightly been said to entail the existence of judicial remedies for the violation of legal rights, ${ }^{2}$ and, relatedly, judicial power that is coextensive with legislative power. ${ }^{3}$ While the Constitution itself imposes numerous legal obligations on the states ${ }^{4}$ and gives Congress the power to impose additional obligations, ${ }^{5}$ the Eleventh Amendment by its terms prevents the federal courts from entertaining suits against the states brought by citizens of other states or of foreign states. ${ }^{6}$ Although scholars have argued that the Amendment can be read in such a way as not to withdraw federal jurisdiction over cases arising under federal law, ${ }^{7}$ the Supreme Court in Hans $v$.

1. See, e.g., John Norton Pomeroy. The Supreme Coun and Siate Repudionon-The Virginua and Louisiana Cases, 17 AM. L. REv. 684, 684-85 (1883) (criticizing "national disgrace" resulung from Eleventh Amendment decisions that would prevent enforcement of legal rights aganst states), see also Vicki C. Jackson, The Supreme Count, the Eleventh Amendment, and Stase Soveresgn Immunin: 98 YAlE L.J. 1, 3-4 (1988) (arguing that Eleventh Amendment is "in tension with" rule-of-law maxims described below).

2. Chief Justice Marshall put it most famously in Marburn' v. sfadison: "The government of the Unuted States has been emphatically termed a government of laws, and not of men. It will ceratuly cease to deserve this high appellation, if the laws furnish no remedy for the violatuon of a vested legal right." 5 L.S. (5 Cranch) 137, 163 (1803).

3. As Alexander Hamilton explained: "If there are such things as poliucal axioms. the propnety of the judicial power of a government being coextensive with its legislatuve may be ranked among the number." THE FEDERALIST NO. 80, at 476 (Alexander Hamilton) (Clinton Rossiter ed. 1961). In Osborn v: Bank of the United States, 22 U.S. (9 Wheat.) 738 (1824). Chief Justice Marshall wrote for the Court that judicial and legislative powers of "every well-constructed govemment" must be "co-extensive with each other." id. at 818 , and that "[a]ll governments which are not extremely defoctive in their organization, must possess. within themselves, the means of expounding. as well as enforcing, their oun laws." id. at 818-19.

4. See, e.g., U.S. CONST. art. I, § 10.

5. For example, see New York v. Unired Siates. 505 U.S. 144 (1992). discussed infra Section I.C.

6. The Eleventh Amendment provides, in its entirety, that "[t]he Judicial Power of the United States shall not be construed to extend to any suit in law or equity. commenced or proseculed agaunst one of the United States by Citizens of another State, or by Citizens or Subjects of anj Foreign State." U.S. CoNist. amend. XI. The Court has made it clear that it views the Eleventh Amendment as in some way having given constinutional force, or at least recognition, to a preexisung immunity of the states. For this reason my reference in this Article's title to "Eleventh Amendment immunity" may be misleading. It Hould perhaps be more accurate to refer to an immunity having its source in "postulates" lying behund the Eleventh Amendment and reaffirmed and given constitutional force by u. See Monaco v. Mississippi. 292 U.S. 313, 322 (1934); see also Ex parte New York, 256 U.S. 490, 497 (1921) ("That a stale may not be sued without its consent is a fundamental rule of jurisprudence . . . of which the [Eleventh] Amendment is but an exemplification."). Nevertheless, I shall refer to this immunity as "Eleventh Amendment immunity" for purposes of brevity-and with some justification. as it is this provision of the Consutution that is thought to refiect the immunity's constitutional status. Also for the salie of brevity, and at the cost of some precision (though. I hope, no confusion). I shall refer to the immunity "conferred" on the states by the Eleventh Amendment, as opposed to the immunity of siates "rocognized and given consutuuonal status" by that Amendment.

7. See, e.g., Akhil Reed Amar, Of Sovereignny and Federalism, 96 Y ALE LJ. 1425, 1466-92 (1987); William A. Fletcher, A Historical Interpretation of the Eleventh Amendment: A Narrow Construction of an Affirmative Grant of Jurisdiction Rather Than a Prohibition Aganst Jurnsdiction, 35 STA. L REV. 1033 (1983) [hereinafter Fletcher, Historical lnterpretation]; John J. Gibbons. The Elerenth Amtendment and State Sovereign Immunity: A Reinterpretation, 83 COL.UM. L. REV. 1889 (1983); Jackson, supra notc 1. But cf. William P. Marshail, The Diversity Theon of the Eleventh Amendment: A Cristcal Evalualion. 102 Hiarv. L. REV. 1372 (1989) (disagreeing with diversity thesis). For a reply to Marshall and other crucs, see Correspondence, Exchange on the Eleventh Amendment, 57 U. CHI. L. REV. 117 (1990) (contunuing debate over varying interpretations); and William A. Fletcher. The Diversin Explanation of the Eleventh 
Louisiana ${ }^{8}$ held that it did apply to such cases. Indeed, the Court went further and interpreted the Amendment to protect states from being sued even by their own citizens, ${ }^{9}$ though the Amendment does not so provide. In subsequent cases, the Court has held that the Amendment also protects states from suits brought by foreign states ${ }^{10}$ and Indian tribes, " even though neither category of plaintiff is mentioned in the Amendment. As so construed, the Amendment is in substantial tension with the rule-of-law axiom that for every federal right there must be a remedy enforceable in the federal court: Individuals, foreign states, and Indian tribes cannot enforce their federal rights in federal court suits against the states. ${ }^{12}$

Over the years, the Court has found ways of avoiding some of the rule-oflaw problems posed by the Eleventh Amendment. The most important ameliorative doctrine is the one that we today associate most closely with $E x$ parte Young, ${ }^{13}$ although its roots stretch back to the Founding period. As the Court reads it today, Ex parte Young establishes that a state official does not enjoy immunity under the Eleventh Amendment from suits seeking the prospective enforcement of federal law. ${ }^{14}$ This doctrine greatly alleviates the rule-of-law problems posed by the Amendment, as it enables individuals to obtain a federal court order requiring state officials to conform their future conduct with federal law. Ex parte Young thus means that the Eleventh Amendment inhibits only retrospective relief for a state's past violations of federal law, ${ }^{15}$ but its narrowing of the sphere of the Amendment's practical operation does not dispose of the rule-of-law problems created by the Eleventh Amendment. The rule-of-law ideal insists that federal courts have the power not just to stop ongoing violations of federal law, but also to remedy at least the most egregious past violations as well. ${ }^{16}$

Amendment: A Reply to Critics, 56 U. CHI. L. REV. 1261 (1989) [hereinafter Fletcher, Diversity Explanation].

8. 134 U.S. 1 (1890).

9. See id. at 15.

10. See Monaco, 292 U.S. at 330.

11. See Blatchford v. Native Village of Noatack, 501 U.S. 775, 779-82 (1991).

12. In the interest of brevity, I shall henceforth refer only to suits by, or liability to, individuals, with the understanding that what I say applies equally to foreign states and Indian tribes.

13. 209 U.S. 123 (1908). As discussed below, this doctrine actually has its roots in much earlier decisions and its rationale extends to suits for damages as well.

14. See Pennhurst State Sch. \& Hosp. v. Halderman, 465 U.S. 89 (1984). But cf. infra note 15 (suggesting that Seminole Tribe v. Florida, 116 S. Ct. 1114 (1996), may signal change in Court's interpretation of Ex parte Young).

15. As Seminole Tribe, $116 \mathrm{~S}$. Ct. 1114, shows, the Eleventh Amendment does protect states from being sued eo nomine, even if only prospective relief is sought. But, unless Seminole Tribe signals a major alteration of Ex parte Young doctrine, see Vicki C. Jackson, Seminole Tribe, the Eleventh Amendment and the Evisceration of Ex Parte Young: "The Double Progeny of the Same Evil Birth", 71 N.Y.U. L. REV. (forthcoming 1997), prospective injunctive relief against officials who violate federal law is not barred by the Eleventh Amendment, at least as long as Congress has not foreclosed it. See infra text accompanying notes $106-09$.

16. Akhil Amar defends a strong version of this point, apparently insisting that for every violation of law the legal system must provide for "full remedies." See Amar, supra note 7, at 1489. Richard Failon 
In its 1989 decision in Pennsylvania v: Union Gas Co.." the Cour interpreted the Eleventh Amendment in a way that virtually closed the remaining remedial gap, at least with respect to federal statutory rights. A majority of the Court in that case held that the states' Eleventh Amendment immunity could be abrogated by Congress pursuant to the Interstate Commerce Clause, ${ }^{18}$ a decision that was widely understood to establish that Congress could do so under any of its legislative powers. ${ }^{19}$ Under this regime, Congress could give individuals the power to sue states in federal cour to enforce their federal rights. With respect to statutory rights at least, ${ }^{20}$ this congressional power largely obviated the rule-of-law problems posed by the Eleventh Amendment. ${ }^{21}$ But the Supreme Court overruled Union Gas last term in Seminole Tribe v. Florida, ${ }^{22}$ and held that Congress may not abrogate the states' Eleventh Amendment immunity when legislating under pre-Eleventh Amendment constitutional powers, such as the Commerce Clause. ${ }^{33}$ Although

and Daniel Meltzer defend a weaker version calling for a system of remedies that on the whole keeps govemment tolerably within the law. See Richard H Fallon. Jr. \& Daniel J Meluer. New Law, Non. Retroactivity, and Constitutional Remedies, 104 HARv. L. REv. 1731,1736 (1991) (The tirst pnnaple. which is strong but not always unyielding, calls for effectre redress to individual vicums of constitutional violations. The second, more absolute principle demands a general structure of constututional remedies adequate to keep government within the bounds of law")

17. 491 U.S. 1 (1989).

18. See id. at 23.

19. See Daniel J. Cloheny, Exclusive Jurisdiction and the Eleventh Amendment Recognizing the Assumption of State Court Availability in the Clear Stasement Compromuse. 82 CAL L. REv 1287. 1306-07 (1994). This is how all of the Justices in Seminole Tribe interpreted Unon Gas See Seminole Tribe, 116 S. Ct. at 1126-27; id. at 1133-34 (Stevens. J., dissenung): id. at 1184 (Souter. J . dissenung)

20. With respect to constitutional rights, a remedy aganst the states that depends on affirmature congressional action is not entirely satisfying, as many of the constututuonal obligations of the states are countermajoritarian in nature and the Congress is. in theory at least. responsive to the preferences of electoral majorities. For this reason, the Union Gas decision did not enturely solve the "nght without a remedy" problem. On this issue, see infra Parts $V$ and VI.

21. By retaining a strong presumption that a congressionally imposed obligation of a state does not necessarily carry with it a private right of action for damages agaunst the statc. the Umon Gas regime did continue to pose a sort of rule-of-law problem, for the possibility remanod that a federal statule clearly imposing obligations on states towards individuals would be construed not to provide for retrospecuve relief in favor of such individuals. I am sympathetic to the view that a legal nght unsccompanted by a retrospective remedy is problematic from a rule-of-Jaw perspectuve On thus problem. see Jackson. supra note 15. This problem exists, however, whenever Congress creates a legal obligauon towards tndwiduals but denies such individuals a private right of action for damages, and no one disputes that Congress has the power to do this. This issue is discussed infra Part V. These rule-of-law considerations would cenanily justify a presumption in favor of private retrospective remedies aganst states whenever Congress has imposed on them an obligation towards individuals. At any rate. the rule-of-law problems thit existed under the Union Gas regime were clearly of far less significance wath respect to statutes than under the Seminole Tribe regime, as Congress by speaking clearly could attich a retrospective remedy to its stalutes when it wanted them enforced vigorously and regarded a private retrospecuve remedy as necessany for thus purpose If Congress did not regard such a remedy to be necessary to give efficacy to the stales obligation. then the absence of such remedies does not pose much of a rule-of-law problem. The rule-of-law problems that admittedly arise when Congress enacts a statute but does not provide an effocuve remedy because It does not want the statute vigorously enforced are comparatively low in the hierarchy of nule-of-law concerns. and in any event they are problems we have to live with. since many Supreme Coun decistons clearly accept that Congress has such a power.

22. $116 \mathrm{~S} . \mathrm{CL} 1114$.

23. See id. at 1131 . 
the Seminole Tribe Court reaffirmed its decision in Fitzpatrick v. Bitzer ${ }^{24}$ that Congress has the power to abrogate Eleventh Amendment immunity to enforce the Fourteenth Amendment, ${ }^{25}$ Seminole Tribe resurrects the rule-of-law problems the Eleventh Amendment poses with respect to federal laws having their source in "antecedent" constitutional provisions.

This Article focuses on a recent series of cases that has received far less notice than Union Gas and promises a somewhat different escape from the rule-of-law problems posed by the Eleventh Amendment. Perhaps until now these cases warranted less attention than Union Gas because Union Gas had already largely taken care of, or at least submerged, the rule-of-law problems posed by the Eleventh Amendment. If so, the reversal of Union Gas should raise significantly the doctrinal and theoretical profile of these cases. At the same time, however, Seminole Tribe includes hints that this second escape from the rule-of-law problems posed by the Eleventh Amendment may not long survive.

The first and most important of these cases is McKesson Corp. $v$. Department of Alcoholic Beverages \& Tobacco. ${ }^{26}$ The Court in that case held unanimously that: (1) the Due Process Clause sometimes requires the states to make available to individuals a monetary remedy in their own courts; and (2) the Eleventh Amendment does not bar Supreme Court review of a state court judgment refusing to provide the remedy. Although neither of these holdings was itself novel, ${ }^{27}$ McKesson's juxtaposition of the two illuminated an alternative escape from the rule-of-law problems posed by the Eleventh Amendment. ${ }^{28}$ McKesson seemed to establish that the Amendment does not preclude remedies for state violations of federal rights or foreclose the exercise of federal judicial power to enforce such remedies, but merely defers the involvement of the federal judiciary in enforcing federal liabilities of the states

\section{427 U.S. 445 (1976).}

25. U.S. CONST. amend. XIV, § 5. Section 5 of the Amendment gives Congress the "power to enforce, by appropriate legislation, the provisions of' the other sections of the Amendment.

26. 496 U.S. 18 (1990).

27. The due process holding was foreshadowed in Ward v. Board of County Commissioners, 253 U.S. 17 (1920). The idea that the Eleventh Amendment does not apply to the appellate jurisdiction of the Supreme Cour is usually traced to Cohens v. Virginia, 19 U.S. (6 Wheat.) 264 (1821), but Chief Justice Marshall's opinion in that case does not clearly so hold. See Jackson, supra note 1, at 19-25, 32. Vicki Jackson has argued, however, that post-Cohens, pre-McKesson decisions of the Supreme Court clearly establish that Eleventh Amendment immunity does not apply to the Supreme Court's appellate jurisdiction. See id. at 25-32. For a discussion of these cases, see infra Subsection III.A.1.

28. This understanding of the Eleventh Amendment had been defended at some length by Vicki Jackson two years earlier. See Jackson, supra note 1, at 73-75. Other commentators who espoused the forum-allocation view before McKesson include Nicole A. Gordon \& Douglas Gross, Justiciability of Federal Claims in State Court, 59 NoTRE DAME L. Rev. 1145, 1146-47 (1984); Louis E. Wolcher, Sovereign Immunity and the Supremacy Clause: Damages Against States in Their Own Courts for Constitutional Violations, 69 CAL. L. REV. 189 (1981); and William L. Taylor, Note, Section 1983 in Siate Court: A Remedy for Unconstitutional State Taxation, 95 YALE L.J. 414, 417-18 (1985). Commentators taking the forum-allocation position since McKesson include Cloherty, supra note 19. See also infra note 34 (citing additional scholars who have embraced forum-allocation interpretation). But cf. infra notc 198 (citing scholars who have expressed skepticism about forum-allocation view). 
until the state courts have had a chance to afford the required relief. The following year, in Hilton v. South Carolina Public Railways Commission, ${ }^{29}$ the Court held that the Federal Employers' Liability Act subjects states to monetary liability to individuals, even though the Eleventh Amendment bars such individuals from recovering damages against the states in federal cour. The Court said that "the Supremacy Clause makes that statute the law in every State, fully enforceable in state court. ${ }^{300}$ Finally, in Reich $v$ : Collins, ${ }^{31}$ the Court reaffirmed McKesson's due process holding, unanimously, and added that while the Eleventh Amendment bars individuals from seeking the constitutionally required remedy against the states in the lower federal courts, the states are not free to deny the remedy in their own courts. ${ }^{32}$

These three decisions reflect a view of the Eleventh Amendment as purely a forum-allocation principle. As construed in these cases, the Amendment has no bearing on Congress's power to regulate the states and subject the states to damage liability to individuals for violating such regulation. If the Constitution or a federal statute imposes such liability on the states, then the Supremacy Clause requires the states to award such damages in their own courts. If state courts decline to do so, the U.S. Supreme Cour may review their decisions. The Amendment, on this view, limits only the original jurisdiction of the federal courts. Its function is merely to place the initial responsibility of adjudicating claims against the states on the state cours, whose compliance with the federal obligation to pay damages to individuals can be monitored by the Supreme Court on appeal. Indeed, the McKesson/Hilton/Reich understanding of the Eleventh Amendment may even permit Congress to authorize review by the lower federal courts of state court decisions rendered in suits against the states based on federal law. ${ }^{33}$ If so understood, the Eleventh Amendment is far from the embarrassment to the United States's rule-of-law aspirations that its detractors describe it to be. It is at worst a nuisance to federal rightholders, postponing but not barring federal judicial enforcement of federal laws making states liable in damages to individuals.

Many scholars had concluded after this trio of cases that the Supreme Court had definitively embraced the forum-allocation interpretation of the Eleventh Amendment, ${ }^{34}$ but now it appears that the solution these cases

29. 502 U.S. 197 (1991).

30. Id. at 207 .

31. 115 S. CL. 547 (1994).

32. See id. at 549 .

33. Whether it does or not depends on whether the Eleventh Amendment was found inapplicable in McKesson because what was at issue was appellate junsdicuon. or because what was al issue was the Supreme Court's exercise of appellate jurisdiction. To the extent that the Mckesson Court was relying on Cohens $v$. Virginia's holding that a writ of error is not a "suut" for Eleventh Amendment purposes. see McKesson Corp. v. Deparment of Alcoholıc Beverages \& Tobacco. 496 U.S. 1S. 26-27 (1990). u would appear that its holding has to have been that the Eleventh Amendment is inapplicable to federal appeals from the state courts, see id., whether the appeal goes to the Supreme Cour or some other federal court

34. See, e.g., ERWI CHEMERINSKY, FEDERAL JURISDICTION 385-86 (2d od 1994) indeed. Henry 
appeared to bring to the rule-of-law problems posed by Hans may not survive Seminole Tribe. There are indications in that opinion that the Court does not regard the Eleventh Amendment as a mere forum-allocation principle. Most significantly, the Court indicated that the Supreme Court "is empowered to review a question of federal law arising from a state court decision where a state has consented to suit." ${ }^{\text {"35 }}$ This suggests that a state may avoid the exercise of federal judicial power simply by refusing to consent to a suit against it in its own courts. If so, then the rule-of-law problems discussed above reemerge. This and other statements in Seminole Tribe reflect an understanding of Eleventh Amendment immunity sharply at odds with the McKesson line of cases. They suggest that the Court regards the Eleventh Amendment as conferring on states an immunity from retrospective liability to individuals for their violations of federal law. They suggest, in other words, that the Court understands the Eleventh Amendment to establish that nothing in the Constitution requires or authorizes the courts (or gives Congress the power to require the courts) to award damages against states for the violation of their federal obligations to individuals. States are free to award such damages if they wish, but they are not required to do so by federal law.

Whether the Eleventh Amendment precludes Congress from subjecting states to damage liability to individuals, or merely requires that any liability Congress chooses to impose be pursued initially in state courts is, of course, of enormous significance. To be sure, Congress would retain the power in either case to impose obligations on the states under Article I, such as the obligation not to infringe copyrights or patents. Under Ex parte Young, those obligations would be enforceable prospectively against state officials even if private damage actions were unavailable in either state or federal court. The question is whether, after Seminole Tribe, Congress's arsenal of potential enforcement mechanisms to give efficacy to the obligations it imposes on the states includes private damage actions. In other words, may Congress confer on individuals a right to damages from states that infringe their patents or

Monaghan is so convinced that these cases established the forum-allocation view that he recently dismissed the contrary suggestions in Seminole Tribe as "plainly wrong." Henry Paul Monaghan, Comment, The Sovereign Immunity "Exception", 110 HARV. L. REV. 102, 125 n.161 (1996). For the reasons discussed in Parts III and IV, I would not be so sure that the suggestion was wrong, even if the test of the "rightness" of a Supreme Court decision were its conformity with prior Supreme Court decisions.

State courts themselves have never been persuaded that they are obligated under the Supremacy Clause to entertain federal claims that cannot be maintained in federal court because of the Eleventh Amendment. See, e.g., Weppler v. School Bd., 311 So. 2d 409 (Fla. Dist. Ct. App. 1975); Board of Comm'rs v. Splendour Shipping \& Enters., 255 So. 2d 869 (La. Ct. App. 1972); Widgeon v. Eastem Shorc Hosp. Ctr., 479 A.2d 921 (Md. 1984); Morris v. Massachusetts Maritime Academy, 565 N.E.2d 422 (Mass. 1991); Maloney v. New York, 144 N.E.2d 364 (N.Y. 1957); Mossman v. Donahey, 346 N.E.2d 305 (Ohio 1976); Lyons v. Texas A\&M Univ., 545 S.W.2d 56 (Tex. Civ. App. 1977, writ ref'd n.r.e.); Gross v. Washington State Ferries, 367 P.2d 600 (Wash. 1961). But see Clover Bottom Hosp. \& Sch. v. Townsend, 513 S.W.2d 505 (Tenn. 1974) (acknowledging obligation).

35. Seminole Tribe v. Florida, 116 S. Ct. 1114, 1131 n.14 (1996) (citing Cohens v. Virginia, 19 U.S. (6 Wheat.) 264 (1821)) (emphasis added). 
copyrights-a right enforceable initially only in state courts, but subject to federal court review $?^{36}$ Or does the Eleventh Amendment immunize the states from any such liability?

This Article examines this basic contradiction between McKesson and Seminole Tribe concerning the nature of Eleventh Amendment immunity and considers how the two cases might be reconciled. Part I defines more precisely the two competing interpretations of the Eleventh Amendment, which I call the "forum-allocation" interpretation and the "immunity-from-liability" interpretation, and explains the relationship between both interpretations and Congress's power to impose obligations on the states, a subject that has been addressed by the Court under the rubric of the Tenth Amendment rather than the Eleventh. Part II reviews the support in the pre-Seminole Tribe decisions of the Supreme Court for the forum-allocation interpretation. Part III describes the Seminole Tribe case and examines the statements in the Court's opinion that are difficult to square with the forum-allocation interpretation. Part III then reviews the pre-Seminole Tribe support for the immunity-from-liability interpretation and concludes that, to the extent that the Seminole Tribe decision supports it, it is part of a long line of Supreme Cour authority that conflicts with the forum-allocation interpretation.

Part IV considers another problem created by the Seminole Tribe holding, a problem that appears at first to take us far afield of this Article's main concerns, but that on closer inspection turns out to be quite perinent. The Seminole Tribe Court held that Eleventh Amendment immunity cannot be abrogated by Congress pursuant to its Article I powers, but can be abrogated pursuant to its power to "enforce" the Fourteenth Amendment. ${ }^{37}$ The Fourteenth Amendment includes a clause that prohibits the states from depriving people of liberty or property without due process of law. It is well established that legislatures may create "property" rights for purposes of this clause by placing mandatory obligations on states vis-à-vis individuals. This suggests an easy way for Congress to evade the Court's holding in Seminole Tribe: Impose mandatory obligations on states pursuant to Article I, thus giving individuals a "property" interest, and then abrogate the state's Eleventh Amendment immunity to "enforce" the states' due process obligations with respect to this newly created property. Indeed, Congress has already attempted to abrogate the states' immunity using just this theory. ${ }^{38}$ Of course, recognizing Congress's power to abrogate Eleventh Amendment immunity in this fashion threatens to eviscerate Seminole Tribe's holding that Congress may not abrogate under Article I. I call this the abrogation reductio.

36. Under the current statutory scheme, the federal courts possess exclusive junsdiction over claums under these statutes. See infra Section III.A.

37. See Seminole Tribe, $116 \mathrm{~S}$. Ct. at 1127-28.

38. It has invoked this theory in justifying its abrogation of the states' Eleventh Amendment ummunty from damage liability in patent and trademark cases. See infra notes 278-82 and accompanying text. 
My search for an escape from the reductio in Part IV requires an examination of doctrine in a number of related areas, including the scope of Congress's power to "enforce" the Fourteenth Amendment under Section 5 of that Amendment. The most promising escape from the reductio relies on McKesson, in conjunction with related procedural due process cases. Examining McKesson's bearing on the abrogation reductio offers several insights into the nature of Eleventh Amendment immunity. It shows, first, that the conflict between McKesson and the immunity-from-liability interpretation of the Eleventh Amendment is deeper than it at first appeared. Rather than being an example of one instance in which the Constitution requires a remedy against states, McKesson appears to stand for the proposition that whenever federal law places a mandatory obligation on the states vis-à-vis individuals, the Due Process Clause itself requires a damage remedy if the state violates the obligation without offering a predeprivation hearing and no other remedy would cure the injury. Although McKesson and related due process cases do supply a rationale for escaping the abrogation reductio-a rationale consistent only with the forum-allocation interpretation of the Eleventh Amendment-analyzing McKesson's implications exposes vulnerabilities of the conventional reading of that case that ultimately lead to its unraveling. Specifically, the analysis places McKesson in conflict with decisions recognizing Congress's power to place mandatory obligations on states vis-àvis individuals without granting individuals a damage remedy.

To avoid this conflict, and to reconcile McKesson with doctrine in other areas as well, I propose in Part V a reinterpretation of McKesson that would save what I regard as its most important insight, its recognition of the importance of retrospective relief for the violation of constitutional rights. The proposed reinterpretation would read the case to establish a constitutional right to damages from state officials responsible for violating the Constitution, rather than from the states themselves, a right of action having its source in the Supremacy Clause, rather than the Due Process Clause. This reinterpretation of $\mathrm{McKesson}$ does not require rejecting the forum-allocation interpretation of the Eleventh Amendment, but it does make possible a reading of McKesson that would reconcile it with Seminole Tribe's suggestion that a state's "consent" to suit in its own courts is a condition of the Supreme Court's jurisdiction to review state court decisions against states. It thus removes McKesson and Reich from the ranks of the cases supporting the forumallocation interpretation and leaves that interpretation on considerably weaker ground.

Part VI explores the options that remain open to Congress under the immunity-from-liability interpretation of the Eleventh Amendment to give efficacy to the obligations it validly imposes on the states, and it examines more generally the rule-of-law ramifications of adopting that interpretation. I 
conclude that as long as McKesson and other cases are understood to recognize a constitutional right of individuals to damages from state officials who have willfully violated their constitutional rights, ${ }^{39}$ and as long as Congress retains the power to make such officials personally liable in damages for violating obligations that Congress has validly imposed on the states, ${ }^{20}$ the rule-of-law problems with an immunity-from-liability interpretation of the Eleventh Amendment are not severe. Indeed, it is not at all clear that the forumallocation interpretation is superior to the immunity-from-liability interpretation from a rule-of-law perspective. The availability of damages from state officials appears to satisfy tolerably well the demand for effective sanctions for government violations of law. The immunity-from-liability interpretation appears to come out ahead, however, when other rule-of-law values are taken into account, values such as respect for precedent and the coherence in law. Among the most pertinent demands of the rule of law is its demand that the law be settled and clear. It is this test that the Court's current Eleventh Amendment jurisprudence clearly fails. In the end, which of the two interpretations of the Amendment the Court adopts is less important from a rule-of-law perspective than that it clearly and definitively adopt one position and permit the rest of us to arrange our affairs accordingly.

\section{THE COMPETING INTERPRETATIONS OF THE ELEVENTH AMENDMENT}

In this Part, I examine the varying ways in which the Eleventh Amendment may be interpreted and the implications of each interpretation. In Section A, I trace the history of the "diversity interpretation" of the Amendment. I explore the Supreme Cour's initial rejection of this interpretation, the withering scholarly attacks that culminated in the Cour's eventual adoption of what might be regarded as a version of the diversity interpretation in Union Gas, and the Court's recent change of heart in Seminole Tribe. As I will explain below, adopting the diversity interpretation would render largely moot the issues I develop in this Aricle. Because the Court rejected this interpretation in Seminole Tribe, Section B describes the central features of the forum-allocation and immunity-from-liability interpretations. In Section C, I explain the relationship between both interpretations and the Court's approaches in recent years to questions of congressional powers to impose primary obligations on the states under Article I. I here examine the complex relationship between the Court's Tenth Amendment jurisprudence and the competing interpretations of the Eleventh Amendment on which this Article focuses.

39. See infra Par V.

40. See infra notes $448-58$ and accompanying text. 


\section{A. The Rise and Fall of the Diversity Interpretation of the Eleventh Amendment}

For a number of years now, the Supreme Court's approach to the Eleventh Amendment has been the subject of great controversy and intense scrutiny. With rare unanimity, scholars have argued that the Supreme Court's early decision in Hans v. Louisiana ${ }^{41}$ was fundamentally mistaken and should be reversed. ${ }^{42}$ In Hans, the Court held that even though the Eleventh Amendment applies by its terms only to suits against states by citizens of other states or foreign states, the Amendment protects states from being sued in federal court by its own citizens, even in cases arising under federal law. ${ }^{43}$ The Court reasoned that the Amendment was adopted to overrule the Supreme Court's decision in Chisholm v. Georgia, ${ }^{44}$ in which the Court had held that the states had given up their sovereign immunity when they adopted a Constitution that under Article III subjected them to the federal judicial power in, inter alia, cases between a state and citizens of another state. The Eleventh Amendment, the Hans Court held, served to restore and constitutionalize the original understanding that states would be immune from being sued by private individuals. Since then, the Court has elaborated a complex jurisprudence of state sovereign immunity under the rubric of the Eleventh Amendment, but one that bears little relation to the Amendment's text. In particular, the Court has held that the Amendment shields states from suits by foreign states ${ }^{45}$ and Indian tribes, ${ }^{46}$ even though neither category of plaintiff is mentioned in the Amendment, and that it applies to suits in admiralty ${ }^{47}$ even though the Amendment refers only to suits at law and in equity. By contrast, the Court has held that the Amendment does not apply to suits brought by the United States ${ }^{48}$ or by sister states, ${ }^{49}$ to nonfederal actions brought by individuals in the state courts, ${ }^{50}$ to suits against state officials seeking prospective relief

41. 134 U.S. 1 (1890).

42. See Jackson, supra note 1, at 4-5. Scholars critical of Hans include, in addition to those cited supra note 7, CLYDE E. JACOBS, THE ELEVENTH AMENDMENT AND SOVEREIGN IMMUNITY (1972); JOHN V. ORTH, THE JUdicial POWER OF THE UNITED STATES: THE ElEVENTH AMENDMENT IN AMERICAN HISTORY (1987); David E. Engdahl, Immunity and Accountability for Positive Governmental Wrongs, 44 U. CoLo. L. REV. 1 (1972); and Suzanna Sherry, The Eleventh Amendment and Stare Decisis: Overruling Hans v. Louisiana, 57 U. CHI. L. REV. 1260 (1990). Even scholars who are critical of "revisionist" Eleventh Amendment scholarship are critical of Hans. See Lawrence C. Marshall, Fighting the Words of the Eleventh Amendment, 102 HARV. L. REV. 1342, 1343 (1989).

43. See Hans, 134 U.S. at 15.

44. 2 U.S. (2 Dall.) 419 (1793).

45. See Monaco v. Mississippi, 292 U.S. 313, 330 (1934).

46. See Blatchford v. Native Village of Noatack, 501 U.S. 775, 779-82 (1991).

47. See Ex parte New York, 256 U.S. 490,497 (1921).

48. See United States v. Mississippi, 380 U.S. 128 136-38 (1965); United States v. Texas, 143 U.S. $621,643-46$ (1892).

49. See Kansas v. Colorado, 206 U.S. 46, 83 (1907).

50. See Nevada v. Hall, 440 U.S. 410, 418-21 (1979). 
from violations of federal law, ${ }^{\text {st }}$ or to suits seeking damages from individual defendants who hold public office. ${ }^{52}$

Scholars have objected most strenuously to the Cour's conclusion in Hans that the Eleventh Amendment grants states constitutional immunity from suits arising under federal law. While recognizing that sovereign states at the time of the Constitution's framing were thought to possess immunity from private lawsuits, revisionist scholars ${ }^{53}$ have denied that either Article III or the Eleventh Amendment was intended to make that immunity applicable to cases arising under "supreme" federal law. ${ }^{54}$ The Court has held that the Constitution itself places certain legal obligations on states vis-à-vis individuals and empowers Congress to impose additional obligations. ${ }^{55}$ To recognize state immunity from federal jurisdiction in cases arising under federal law would be to place awkward, and possibly severe, obstacles in the way of the enforcement of the obligations towards individuals that the Constitution plainly placed on the states. If the Amendment's Framers had intended to leave such a gap in the federal government's power to enforce the legal obligations it has the power to impose, they certainly could have chosen clearer language to do so.

Much of the revisionist scholarship on the Eleventh Amendment appears to have been driven by profound discomfort with this enforcement gap created by the Hans interpretation of the Eleventh Amendment. ${ }^{56}$ I too find such a gap to be constitutionally problematic. As explained below, however, I am satisfied that the "fictions" that the Court has used to alleviate the problems created by Hans reduce the gap to manageable proportions, even if the immunity conferred by the Eleventh Amendment is thought to operate at the level of remedy. I discuss below the opportunities that remain available to Congress and the courts to "manage" this gap, but first I shall discuss the solution proposed by the diversity theorists. This solution would have entirely bridged the gap, and it would have done so in a way that would render largely moot the question that is the focus of this Article. The Supreme Cour flined

51. See Ex parte Young, 209 U.S. 123, 150-54 (1908).

52. See, e.g., Scheuer v. Rhodes, 416 L.S. 232. 237-38 (1974).

53. The term is not mine. See George D. Brown, Has the Supreme Court Confessed Error on the Eleventh Amendment? Revisionist Scholarship and State Immuniñ: 68 N.C. L. REV 867. 871-7S (1990)

54. This is the thrust of the "diversity" explanation of the Eleventh Amendment. See infra text accompanying notes 63-64.

55. See, e.g., New York v. United States. 505 U.S. 144, 160 (1992) (affirming Congress's power to make applicable to states "generally applicable" laws imposing obligatuons (owards indıviduals): Fletcher v. Peck, 10 U.S. (6 Cranch) 87, 135-39 (1810) (finding that Contracts Clause prohibits states from impairing their own contracts with individuals).

56. Depending on whether one views the immunity as a forum-allocation panciple or an unmunty from damage liability (an issue to which revisionist scholars have not devoted much attention). the Amendment will be viewed as doing one of two very different things. If the immunity is from lability, the Amendment prevents Congress from subjecting states that volate their obligations to individuals to damage liability to such individuals, thus creating a gap between promary obligations and secondary, or remedial. obligations. If the immunity is jurisdictional, however, then the Amendment pemits Congress to impose such liability but prevents the federal courts from enforcing 4 , thus creaung a gap betucen secondary obligation and federal judicial power. 
briefly with this approach, but then gave renewed significance to this question by abandoning the approach in Seminole Tribe.

Most scholars agree with the Hans Court's premise that the Amendment's purpose was to reverse Chisholm. Revisionist scholars, however, disagree with the Hans Court about which feature of Chisholm the Eleventh Amendment was intended to reverse. Some stress that the principal flaw of the Chisholm decision, the one the Framers of the Eleventh Amendment sought to correct, was the one that caused Justice Iredell to dissent. In particular, Congress had not specifically withdrawn the states' immunity from private lawsuits, and Justice Iredell argued that Article III should not be construed as itself an abrogation of the states' common law sovereign immunity. ${ }^{57}$ On this view, the Eleventh Amendment does not give constitutional status to the states' sovereign immunity; it merely reversed Chisholm's holding that the Constitution itself did away with this immunity. Adherents to this view accept that state sovereign immunity remains as a common law immunity, but they maintain that, as such, it is subject to plenary abrogation by Congress. ${ }^{58}$

Other scholars stress that Chisholm was an action in assumpsit involving an ordinary commercial dispute between an individual and a state. They argue that the Eleventh Amendment merely reversed the Chisholm Court's holding that the states could be sued in federal court by individuals on nonfederal causes of action. ${ }^{59}$ This interpretation makes some sense in light of the Amendment's reference to suits brought by citizens of other states or foreign states, but not suits brought by the states' own citizens. ${ }^{60}$ Since the latter cases can be brought in federal court only if the action is based on federal law, ${ }^{61}$ the Amendment could be read simply to withdraw two of the

57. See Chisholm v. Georgia, 2 U.S. (2 Dall.) 419, 435-37 (1793) (Iredell, J., dissenting).

58. See Martha A. Field, The Eleventh Amendment and Other Sovereign Immunity Doctrines: Congressional Imposition of Suit upon the States, 126 U. PA. L. REV. 1203, 1261-62 (1978) [hereinafter Field, Congressional Imposition]; Martha A. Field, The Eleventh Amendment and Other Sovereign Immunity Doctrines: Part One, 126 U. PA. L. REV. 515, 540-45 (1978); John E. Nowak, The Scope of Congressional Power to Create Causes of Action Against State Governments and the History of the Eleventh and Fourteenth Amendments, 75 CoLUM. L. REv. 1413, 1441-45 (1975); Laurence H. Tribe, Intergovernnemtal Immunities in Litigation, Taxation, and Regulation: Separation of Powers Issues in Controversies About Federalism, 89 HARV. L. REV. 682, 693-96 (1976).

59. See Chisholm, 2 U.S. at 428.

60. Article III extends the judicial power of the United States to, inter alia, "Cases . . arising under this Constitution, the Laws of the United States, and Treaties made, or which shall be made, under their Authority," and "Controversies . . . between a State and Citizens of another State . . . and between a State, or the Citizens thereof, and foreign States, Citizens or Subjects." U.S. CONST. ant. III, $\S 2$. The Eleventh Amendment provides, in its entirety: "The Judicial power of the United States shall not be construed to extend to any suit in law or equity, commenced or prosecuted against one of the United States by Citizens of another State, or by Citizens or Subjects of any Foreign State." Id. amend. XI. The diversity interpretation holds that the Amendment merely repealed the state-citizen and state-alien diversity provisions insofar as they gave the federal courts jurisdiction over suits against the states.

61. Here I include admiralty, which is today regarded as federal law. See Moragne v. States Marine Lines, Inc., 398 U.S. 375, 388-93 (1970). But cf. Romero v. International Terminal Operating Co., 358 U.S. 354, 359-80 (1959) (holding that general federal question statute, 28 U.S.C. $\$ 1331$ (1994), does not confer jurisdiction over admiralty cases). I am also using "based upon" broadly to accommodate Congress's power (if any) to confer "protective" jurisdiction. See generally Paul J. Mishkin, The Federal "Question" in the 
"diversity" bases of federal jurisdiction over suits against states, leaving untouched the federal judicial power over cases "arising under" federal law. This construction neatly solved the problem that the Hans interpretation posed for the effective enforcement of the federal obligations of the states, for under this interpretation, the Eleventh Amendment does not reach cases arising under federal law.

By the late 1980s, these strands of revisionist Eleventh Amendment scholarship coalesced into what became known as the "diversity" interpretation. ${ }^{63}$ Although they differ on some details, diversity scholars agree that the Amendment should not be understood to bar Congress from conferring jurisdiction on the federal courts over cases arising under federal law but should instead be read to preclude only federal jurisdiction over suits against states predicated solely on diversity. ${ }^{64}$ Most of them also agree that state sovereign immunity could continue to play a role as a subconstitutional doctrine tied loosely or not at all to the Eleventh Amendment, but they all insist that Congress has plenary power to abrogate any such immunity pursuant to any of its legislative powers.

The question that is the focus of this Aricle-is Eleventh Amendment immunity just a forum-allocation principle or does it also create an immunity from federal liability? - would of course not even arise for a scholar who did not regard the Eleventh Amendment to be applicable at all to suits arising under federal law. If the scholar accepted the existence of state sovereign immunity but regarded it merely as a matter of common law, the question whether this subconstitutional immunity is merely an immunity from original federal jurisdiction or also an immunity from federal liability would be a relatively unimportant one, for in either case the "immunity" could be withdrawn by Congress. Indeed, it seems awkward to call it an "immunity" at all if Congress has the power to withdraw it. Such an "immunity" would operate merely as a presumption that generally applicable laws have not been

District Courts, 53 COLUM. L. REv. 157 (1953).

62. See Fletcher, Historical Interpretation, supra note 7, at 1033; Gibbons, supra note 7. at 1889

63. In addition to the articles cited above, see Amar. supra note 7. at 1425; and Jackson. supra note 1. A minority of scholars has rejected aspects of the interpretation. See Marshall, supra note 42: Marshall. supra note 7; Calvin R. Massey, State Sovereignty and the Tenth and Eleventh dmendmenis. 56 U. CIII L. REV. 61 (1989).

64. Some scholars appear to go even further and mantain that the Eleventh Amendment limited only the federal judiciary's power to exercise jurisdiction directly under the Consutution. not Congress's power to grant federal jurisdiction. See Nowak, supra note 58. at 1412. If so, then Congress would presumably be free to confer jurisdiction over suits against states not based substantuvely on federal law. Since the jurisdiction of the lower federal courts is entirely dependent on congressional authonzation, the Eleventh Amendment as interpreted by Professor Nowak would only affect the Supreme Court's junsdiction. The interpretation is highly implausible. It is true that the Amendment limits only the "judiejal power." but it is well understood that the limits on the judicial power are lımits on Congress's power to confer junsdiction on the lower cours. Justice Jackson's suggestions to the contrary in Nanonal Murual Insurance Co. v: Tidewater Transfer Co., 337 U.S. 582, 592 (1949) (plurality opinion), were clearly rejected by a majonty of the Cour. See id. at 626 (Rutledge. J., concumng); id. at 640-4l (Vinson. CJ., dissentung): td. at 655 (Frankfurter, J., dissenting). 
made applicable to the states. The question whether this type of immunity is an immunity from original federal jurisdiction only or an immunity from liability as well might be relevant in determining whether Congress, in order to remove it, need only make known its intent to subject states to suit in federal court or must also express its intent to make states liable in damages to individuals. Few diversity scholars have addressed this issue at all. ${ }^{65}$

On the Supreme Court, the first signs of dissatisfaction with the Hans line of cases came in dissenting opinions by Justice Brennan. At first, Brennan advocated a literal interpretation of the Amendment, under which the Amendment would apply to suits "arising under" federal law, but only if the suit was brought by a citizen of a different state or of a foreign state. ${ }^{66} \mathrm{He}$ combined this view, however, with a broad theory of congressional power to abrogate sovereign immunity under Article $\mathrm{I} .{ }^{67}$ Eventually, Brennan embraced the diversity interpretation, under which the Amendment would have no application to suits arising under federal law and the states would enjoy at best a subconstitutional immunity subject to congressional abrogation. ${ }^{68}$ Three of his colleagues concurred in this view, ${ }^{69}$ and at one point the Court was evenly divided on whether to adopt it. ${ }^{70}$ In Union Gas, however, Justice Brennan switched gears in an apparent attempt to garner a fifth vote. Rather than press the diversity interpretation, he now relied on his reasoning in Parden $v$. Terminal Railway ${ }^{71}$ to extend to the Commerce Clause the Court's holding in Fitzpatrick v. Bitzer ${ }^{72}$ that Congress has the power to abrogate Eleventh

65. A notable exception is Jackson, supra note 1, who gave the issue sustained attention in 1988. This Article argues that the forum-allocation interpretation is not as well grounded as Jackson suggests. William Fletcher also gave more than passing consideration to the issue. See Fletcher, Historical Interpretation, supra note 7. While Fletcher concludes that the Eleventh Amendment has no bearing on Congress's power to subject states to damage liability, he acknowledges that other provisions of the Constitution may limit Congress's power in this respect. He argues that the scope of Congress's power to subject states to damage liability to individuals should be regarded as a clause-specific question of substantive law, a question the courts should approach as a matter of interpreting the specific constitutional provision that assertedly gives Congress the power to legislate substantively on the matter. See id. at 1107 . I suggest below that the Cour may now understand this issue to be govemed by the Eleventh Amendment, which distinguishes only between pre- and post-Fourteenth Amendment obligations of the states.

66. See Employees of Dep't of Pub. Health \& Welfare v. Department of Pub. Health \& Welfare, 411 U.S. 279, 313 (1973) (Brennan, J., dissenting).

67. The theory was that the states surrendered their sovereignty to the extent that they gave Congress the power to legislate under Article l. See Parden v. Terminal Ry., 377 U.S. 184, 196-97 (1964).

68. See Atascadero State Hosp. v. Scanlon, 473 U.S. 234, 261-63, 301 (1985) (Brennan, J., dissenting).

69. Justices Marshall, Blackmun, and Stevens concurred in Brennan's Atascadero dissent. See id. at 247 (Brennan, J., dissenting).

70. In Welch v. Texas Department of Highways \& Public Transportation, 483 U.S. 468 (1987), Justice Scalia reserved judgment on the question, see id. at 495-96 (Scalia, J., concurring in part and concurring in judgment), but in Union Gas, he ultimately came down in favor of affirming Hans, see Pennsylvania v. Union Gas Co., 491 U.S. 1, 35 (1989) (Scalia, J., concurring in part and dissenting in part).

71. 377 U.S. at 196-97 (suggesting that states waived their sovereign immunity from suit under federal statutes when they ratified Constitution giving Congress power to enact those statutes).

72. 427 U.S. 445 (1976). 
Amendment immunity under the Fourteenth Amendment. ${ }^{73}$ Justice White apparently agreed that the reasoning of Fitzpatrick could not be confined to obligations imposed on states under the Fourteenth Amendment and so he provided a fifth vote for the holding that Congress may abrogate Eleventh Amendment immunity pursuant to its power to regulate interstate commerce as well. ${ }^{74}$ Union Gas was widely understood to establish that the Eleventh Amendment could be abrogated by Congress under any of its legislative powers. ${ }^{75}$

Although the Union Gas decision did not explicitly adopt the diversity interpretation, it produced virtually the same result. Proponents of the diversity theory maintain that the Amendment has no application in federal question cases, but they accept a subconstitutional doctrine of state sovereign immunity. The doctrine is subconstitutional in the sense that Congress may abrogate it. The plurality in Union Gas did not say that Eleventh Amendment immunity was not of constitutional stature, but its holding that Congress may abrogate the immunity under any of its legislative powers rendered the immunity subconstitutional in the very sense urged by the diversity theorists. Whether the immunity was an immunity from original federal jurisdiction only or an immunity from federal liability as well was accordingly unimpontant, as in either case Congress had the power to do away with it.

Union Gas was expressly overruled last term in Seminole Tribe, where a majority of the Court held that Eleventh Amendment immunity could not be abrogated under Article $I^{76}$ This decision, of course, resurrects the issue that mattered little under the diversity view. State sovereign immunity is once again beyond Congress's reach, and it is accordingly once again important to know exactly what the Eleventh Amendment prevents Congress from doing. Does it merely prevent Congress from subjecting states to the original jurisdiction of the federal courts, or does it disable Congress from subjecting states to damage liability to individuals?

73. See Union Gas, 491 U.S. at 15-19.

74. The other four Justices in the majority had embraced the diversity interpretation in diascadero. In his concurring opinion, Justice White wrote cryptically that he agreod with Justice Brennan's conclusion. though not all of his reasoning. See id. at 45 (White. J., concurring in judgment in part and dissenting in part).

75. All of the Justices in Seminole Tribe so interpreted the decision. See Semınole Tnbe $r$ Flonds. 116 S. CL 1114, 1126-27 (1996); id. at 1133-34 (Stevens. J.. dissenting): id. al 1184 (Souter. J., dissenting).

76. See id at 1128. Justices Stevens, Souter. Ginsburg. and Breyer dissented. Jusuce Stevens, who had earlier embraced the diversity interpretation, maintaned, as he had done in Unon Gas. that there are two Eleventh Amendments, one having constitutional stature, which Congress may not abrogate, and another having subconstitutional stature and subject to plenary congressional abrogation. See $1 d$. al $11+4$ (Stevens. J., dissenting). Justice Souter (joined by Justices Ginsburg and Breyer) would have affirmed the Unon Gas holding that Congress has the power to abrogate Eleventh Amendment immunity under any of Its legislative powers. They would have interpreted Hans as resting on the lack of an act of Congress expressly withdrawing the states' sovereign immunity. See id. at 1184-85 (Souter, J., dissenung). These three Justuces would thus have accepted the diversity theory in substance if not in name. 


\section{B. The Forum-Allocation and Immunity-from-Liability Interpretations}

Unlike the diversity issue, the issue that is the focus of this Article has not received sustained attention from either judges or scholars, and (perhaps because the Justices have failed to focus on the issue) the Supreme Court's Eleventh Amendment opinions have for some time been sending conflicting signals about it. I shall provisionally put the question this way: Is the immunity conferred on the states by the Eleventh Amendment an immunity from liability under federal law, ${ }^{77}$ or is it merely an immunity from the jurisdiction of the federal courts?

The Amendment's text appears to provide a clear answer to that question. By its terms, the Amendment limits "the Judicial power of the United States." ${ }^{\text {"T }}$ This phrasing suggests that it relates only to federal jurisdiction, but reflection reveals the dichotomy, as posed above, to be a false one. Recognizing this falsity, moreover, permits us to see that the text of the Amendment actually supports the view that the Eleventh Amendment confers an immunity from liability. Whatever the nature of the immunity conferred by the Eleventh Amendment, it is relevant only where retrospective monetary relief ${ }^{79}$ is being sought by individuals. Assume that Eleventh Amendment immunity is "only" an immunity from federal court jurisdiction. Assume further that a federal statute purports to obligate the states to pay damages to individuals under certain circumstances. If no federal court is empowered to enforce that liability, then it is questionable whether the states can be said to be under a legal obligation to pay those damages. ${ }^{80}$ For present purposes, it suffices to observe that a federal liability of the states that is enforceable only in state courts is not an effective liability. It is more like a congressional recommendation that states pay damages to individuals. Chief Justice Marshall

77. The Supreme Court has clearly held that the Amendment does not protect the states from liability under the law of sister states, or from being sued in the courts of sister states. See Nevada v. Hall, 440 U.S. 410, 426-27 (1979). Presumably the Amendment also does not protect the states from being subjected to liability under the laws of foreign states, a liability that would be enforceable in the courts of sister states (if permitted by sister states). Thus, to the extent that the Amendment can be an immunity from liability, it would at best be an immunity from liability under federal law (unless the 6-3 decision in Nevada $v$. Hall were to be revisited).

78. U.S. CONST. amend. XI.

79. See Edelman v. Jordan, 415 U.S. 651, 668-69 (1974), discussed infra Part III. As discussed bclow, suits against state officials for prospective relief from violations of federal law are not barred by the Eleventh Amendment. The Eleventh Amendment is accordingly not an obstacle to individuals sceking prospective relief from continuing violations of federal law by the states. As Seminole Tribe itself reminds us, the Amendment protects states from being sued by private parties in their own names even for prospective relief. Seminole Tribe may further establish that a suit seeking prospective relief from violations of federal statutes may be available only if the statute that imposes the primary obligation does not preclude such relief.

80. In another piece, I not only defend such an understanding of what it means to be under a legal obligation but also argue that the Supremacy Clause embraces such an understanding of the term "law." See Carlos Manuel Vázquez, The Constitution as Law of the Land: The Supremacy Clause and Constitutional Remedies (1997) (unpublished manuscript, on file with author). 
noted in Osborn v. Bank of the United States" that "the legislative, executive, and judicial powers, of every well constructed government are co-extensive with each other" and that "[a]Il governments which are not extremely defective in their organization, must possess, within themselves, the means of expounding, as well as enforcing, their own laws." 82 Marshall was referring to the need for a federal forum to give efficacy to all federal laws. The point is even more compelling when the federal law at issue is one that imposes a liability on the states. It is one thing to rely on state cours to enforce the federal liabilities of private individuals; it is quite another to rely on state courts to enforce the federal liabilities of the states. Whether we consider a liability to be a legal one if it depends on the willingness of the obligated party to comply is a question I leave for another day. Surely it is a liability of questionable efficacy. If all federal courts lack jurisdiction over cases in which individuals seek money damages from the states under federal law, then the states are effectively immune from federal liability to individuals for damages. ${ }^{83}$

In one of its many departures from the text of the Amendment, the Supreme Court has held that the Eleventh Amendment does not constrain the jurisdiction of all federal courts: It does not limit the Supreme Court's own appellate jurisdiction. The most forceful recent articulation of this idea came in McKesson, in which a unanimous Supreme Court concluded that "the [Eleventh] Amendment does not circumscribe our appellate review of statecourt judgments." 84 As discussed below, this decision is one of the cornerstones of the forum-allocation interpretation of the Eleventh

81. 22 U.S. ( 9 Wheat.) 738 (1824).

82. Id at $818-19$.

83. The federal liabilities of the federal government are enforceable only by federal cours. Because both the tribunal and the obligated pary are federal entities, it might be argued that my analysts would require me to say that the federal liabilities of the federal government are not really legal liabılitues eıther. But, the situations are different in important respects. First, the federal couns are constitutionally insulated from pressure from the political branches. See U.S. CoNST. an. III. § I. Socond. the liabiliues of the federal government have been enacted by the federal Congress. Thus pressure from that quarter would serve only to increase the efficacy of the federal liability. By contrast, a damage liability imposed on states from without is likely to be opposed by the political branches of the state governments, and the state courts are not as a general matter insulated from state legislatures or from popular pressures.

The analogy to the sovereign immunity of the United States actually suppons the concluston that state sovereign immunity is an immunity from liability, for the Supreme Coun has treated the sovereign immunity of the United States as negating the existence of any legal right aganst the United Stales. not just precluding access to a court for the enforcement of an existing right. See The Western Mladd. 257 U.S 419,433 (1922) ("Legal obligations that exist but cannot be enforced are ghosts that are seen in the law but that are elusive to the grasp."); cf. Kawananakoa v. Polybank. 205 U.S. 349. 353 (1907) ("[T]here can be no legal right as against the authority that makes the Law on which the nght depends."). For a further defense of the conclusion that a federal liability of states that no federal coun is empowered to enforce is not a legal liability, or is, at any rate, an ineffective liability. see tnfra text accompanying notes $438-10$.

84. McKesson Corp. v. Division of Alcoholic Beverages \& Tobacco, 496 U.S. 18, 28 (1990). On whether the forum-allocation view would permit congress to authonze lower federal cours to hear appeais from state courts in suits against states, see supra note 33. 
Amendment. ${ }^{85}$ The immunity it confers under this view is only an immunity from the original jurisdiction of the federal courts. It has nothing to say about the liability of states to individuals under federal law; it merely channels damage actions by individuals against the states into the state courts. If federal law subjects the states to liability to individuals, the state courts are required by the Supremacy Clause to award the required relief, and, if they do not, McKesson holds that the Supreme Court may reverse their judgments. The Eleventh Amendment, on this view, protects the states' dignity by delaying the exercise of the federal courts' coercive power, but it does not protect state coffers. It assumes that the states will ultimately comply with any federal obligation to pay damages to individuals, and it holds in reserve a federal judicial power to compel such payment if the states prove recalcitrant.

In light of McKesson, the question posed above may be rephrased as follows: Is the immunity conferred by the Eleventh Amendment on the states only an immunity from the original jurisdiction of the federal courts, or is it also (effectively) an immunity from liability to individuals under federal law $?^{86}$ Because the Eleventh Amendment is phrased as a limitation on the "judicial power of the United States," the Amendment's text appears incompatible with the forum-allocation reading, ${ }^{87}$ but the Amendment's text has long ceased to do any dispositive work, and the decisions in McKesson and other Supreme Court cases ${ }^{88}$ seem to reject the immunity-from-liability reading. On the other hand, Supreme Court decisions dating back to Hans, and indeed to Justice Iredell's dissent in Chisholm v. Georgia, ${ }^{89}$ are in substantial tension with the forum-allocation view. Significantly, the Court's most recent pronouncement on the Eleventh Amendment, its opinion in Seminole Tribe, strongly hints that the Court regards Eleventh Amendment immunity as (effectively) immunizing the states from monetary liability to private individuals. The majority stated that the Supreme Court may exercise appellate jurisdiction over suits arising in the state courts "where a State has consented

85. Cf. Jackson, supra note 1 , at 7 (identifying forum allocation as important aspect of Eleventh Amendment doctrine).

86. I shall henceforth describe an immunity of states from the jurisdiction of all federal courts as an immunity from federal liability on the theory that a liability that Congress has the power to impose on the states but only state courts have the power to enforce is no liability at all. Readers who are unwilling to go that far may insert the term "effectively" as indicated in brackets.

As the text indicates, I am not posing an "either-or" choice. It is clear that Eleventh Amendment immunity is at least an immunity from the jurisdiction of the lower federal courts. The question is whether it is also an immunity from liability under federal law. On whether the existence of an immunity from federal court jurisdiction has any relevance if the states are in any event immune from liability under federal law, see infra note 270.

87. The appellate jurisdiction of the Supreme Court can, of course, be no broader than the whole "judicial power of the United States."

88. See cases discussed infra Part II.

89. 2 U.S. (2 Dall.) 419, 429-50 (1793) (Iredell, J., dissenting); see also infra note 238 and accompanying text. The Court has relied on Justice Iredell's dissent in construing the meaning of the Eleventh Amendment. See Hans v. Louisiana, 134 U.S. 1, 18-19 (1890). 
to suit," 90 thus suggesting that a state's successful invocation of sovereign immunity in state court will immunize the state cour decision from Supreme Court review. ${ }^{91}$ This language from Seminole Tribe, and statements to the same effect in other recent cases, ${ }^{92}$ invite a closer look at McKesson and the judicial support for the forum-allocation interpretation of the Eleventh Amendment.

Seminole Tribe is not the only recent decision that suppors the immunityfrom-liability interpretation-indeed, in the previous Term the Court used language that supports it even more clearly ${ }^{93}$-but its principal holding elevates substantially the significance of the issue. As noted, Seminole Tribe overruled Union Gas, in which the Court had held that Congress has the power to abrogate Eleventh Amendment immunity pursuant to any of its Article I powers. By affirming that the Eleventh Amendment is beyond Congress's power to abrogate except in certain circumstances, this decision obviously makes understanding the scope of Eleventh Amendment immunity all the more important.

\section{The Relationship Between the Immunity-from-Liability Interpretation of the Eleventh Amendment and the Court's Tenth Amendment Jurisprudence}

An interpretation of the Eleventh Amendment as limiting not just the original jurisdiction of the federal courts but also Congress's power to subject the states to monetary liability to individuals would arguably encroach upon some of the turf currently occupied by the Court's Tenth Amendment jurisprudence. This Section addresses the relationship between the immunityfrom-liability interpretation and the Cour's recent Tenth Amendment jurisprudence. We might understand the immunity-from-liability interpretation as dividing up the relevant turf along the following lines: While Congress's power to impose obligations on the states is governed by the Court's Tenth Amendment jurisprudence, the availability of remedies for the violation of such obligations is determined by the Eleventh Amendment.

The relationship between the immunity-from-liability interpretation of the Eleventh Amendment and the Court's Tenth Amendment jurisprudence is complex. In Garcia v. San Antonio Metropolitan Transit Authority, the

90. Seminole Tribe v. Florida. 116 S. Ct. 1114,1131 n. 14 (1996).

91. Indeed, the statement suggests that even an unsuccessful invocation of soveresgn immunty in the state courts would preclude the Supreme Court from reviewing a decision on the ments favonng the state

92. See, e.g., Hess, $115 \mathrm{~S}$. Ct. at 400 . Even McKesson itself has language that supports the immunttyfrom-liability interpretation. See infra text accompanying note 128.

93. See Hess, $115 \mathrm{~S}$. Ct. at 400 ("The Eleventh Amendment largely shields States from sutt in federal court without their consent, leaving parties with claims against a State to present them. if the State permits. in the State's own tribunals.").

94. 469 U.S. 528 (1985). 
Court overruled National League of Cities v. Usery, ${ }^{95}$ in which it had held that the Tenth Amendment protected the states from being regulated by Congress in certain spheres-i.e., in areas of the states' "traditional governmental functions." specifying exactly which activities fell within that category, Garcia discarded this limitation. ${ }^{97}$ It held that the Fair Labor Standards Act (FLSA), a federal statute requiring employers to pay employees a minimum wage, could constitutionally be applied to the states acting as employers. In New York $v$. United States, ${ }^{98}$ the Court backtracked somewhat, but left Congress with considerable power to regulate the states. The Court limited Garcia to federal laws that regulate the states as a part of a broader category of regulated parties that includes nonstate actors. ${ }^{99}$ Thus, after New York v. United States, Congress remains free to regulate the states as, for example, employers, as it did in the FLSA.

How does the Eleventh Amendment bear on all of this? The FLSA authorized suits against employers for back pay, and in Garcia the Court permitted the suit to go forward against the San Antonio Metropolitan Transit Authority, a local agency. Because the defendant was not a state agency, as that term is understood in Eleventh Amendment jurisprudence, ${ }^{100}$ the case did not raise an Eleventh Amendment issue. Post-Garcia, the lower courts held that Congress, in amending the FLSA in 1974, clearly expressed its intent to abrogate the states' Eleventh Amendment immunity. ${ }^{101}$ Under the Union Gas holding, Congress had the power to do this, but Seminole Tribe calls into

95. 426 U.S. 833 (1976), overruled by Garcia, 469 U.S. 528.

96. Id. at 852 .

97. To be precise, the Court said that any limits on Congress's power in this regard were not judicially enforceable. See Garcia, 469 U.S. at 556-57. The Court thus left open the possibility that the Tenth Amendment might indeed impose limits, but it held that any such limits were "enforceable" only through the political process. I would question the legal status of constitutional limits that can be "enforced" only through the political process. See Vazquez, supra note 80. Others apparently share this skepticism, for Garcia has come to be understood as holding that the Tenth Amendment does not place limits on Congress's power to regulate the states. See, e.g., Southeastem Pa. Transp. Auth. v. Pennsylvania Pub. Util. Comm'n, 826 F. Supp. 1506, 1518 (E.D. Pa. 1993), aff'd, 27 F.3d 558 (3d Cir. 1994); Karl M. Tilleman, Note, Does the Tenth Amendment Pose Any Judicial Limit on the Commerce Clatuse After Garcia v. San Antonio Metropolitan Transit Authority and South Carolina v. Baker?, 1989 BYU L. REv. 231. Indeed, the Supreme Court itself appears to have so interpreted its Garcia holding. See South Carolina v. Baker, 485 U.S. 505, 512 (1988) (stating that "Garcia left open the possibility that some extraordinary defects in the national political process might render congressional regulation of state activities invalid," thus implying that without such defects such regulation would be valid).

98. 505 U.S. 144 (1992).

99. See id. at 160 .

100. For Eleventh Amendment purposes, a "state" includes a statewide agency but not local governments or local government agencies. See RICHARD H. FALLON, JR. ET AL., HART AND WECHSLER'S THE FEDERAL COURTS AND THE FEDERAL SYSTEM 1056 (4th ed. 1996) [hereinafter HART \& WECHSLER]. For Tenth Amendment purposes, as Garcia itself shows, local governments and local govemment agencics are treated as the state.

101. See Johns v. Stewart, 57 F.3d 1544, 1556 (10th Cir. 1995); Brinkman v. Department of Corrections, 21 F.3d 370. 372 (10th Cir. 1994); Reich v. New York, 3 F.3d 581, 590 (2d Cir. 1993); Halo v. Arizona, 993 F.2d 1387, 1391 (9th Cir. 1993) (en banc). 
question the validity of this abrogation, as the FLSA appears to have been enacted pursuant to the Commerce Clause. ${ }^{102}$ If Eleventh Amendment immunity were merely a forum-allocation principle, then Seminole Tribe would mean that Congress may require states as employers to pay a minimum wage, and it may subject states that violate this obligation to suit by private individuals, but such suits would have to be brought in state courts. The Supremacy Clause would obligate the state courts to enforce the states' statutory obligations, and the Supreme Court through its appellate jurisdiction would have the power to monitor the state courts' compliance with this obligation. ${ }^{103}$ If Eleventh Amendment immunity were an immunity from liability, then Congress would lack the power to subject the states to any monetary liability to individuals. The state courts would thus not be under any obligation to entertain damage actions brought by private individuals in state courts alleging the violation by states of statutes enacted by Congress pursuant to Article I and clearly made applicable to the states (as permitted by $\mathrm{New}$ York v. United States $\left.{ }^{104}\right)$.

102. A federal circuit cour and three district couns have already found this abroganton to be unconstitutional under Seminole Tribe. See Wilson-Jones v. Cavness. Nos. 95-3086. 95-31+3. 1996 U S App. LEXIS 28067 (6th Cir. Oct. 30, 1996); Adams v Kansas, 934 F. Supp 371. 372 (D Kan 1996). Taylor v. Virginia, No. 3:95cv1026, 1996 U.S. Dist. LEXIS 19748 (E.D Va. Dee 18. 1996). Amencan Fed'n of State, County and Mun. Employees v. Virgina, No. 94-097-A. 1996 U'S Dist LEXIS 18810 (W.D. Va. Dec. 13, 1996). In addition, a federal district cour in Alabama has found the abrogation of Eleventh Amendment immunity in the Age Discrimination in Employment Ast (ADEA) vo be unconstitutional under Seminole Tribe. See MacPherson v Lnverstly of Montevallo, 938 F Supp 785. 788-89 (N.D. Ala. 1996). On the other hand, a district court has found the Eleventh Amendment abrogation in the ADEA to be a valid exercise of Congress's power to enforce the Fourtenth Amendmens. See Teichgraeber v. Memorial Union Corp., No. 95-4118-SACS, 1996 U.S. Dist. LEXIS 18131 (D. Kan Nov 26, 1996). Cours have also reached conflicting conclusions on whether Congress's abrogauon of Eleventh Amendment immunity for suits brought under section 106 of the Bankruptcy Act was a valid exercese of its Section 5 power. Compare In re Burke, No. 92-11482, 1996 Banks LEXIS 1614 (S D Ga Dec 16. 1996) (valid), with In re Koehler, No. 4-94-6040, 1997 Bankr. LEXIS 9 (D Minn. Jan. 3. 1997) (Invalud). and In re Charter Oaks Assocs., No. 91-23999, 1996 Bankr. LEXIS 1554 (D Conn. Nov 25, 1996) (invalid), and In re Lush Lawns, Inc., No. 96-13469, 1996 Bankr. LEXIS 1576 (N.D Oho Nov 19, 1996) (invalid). An appellate court has found Congress's abrogation of Eleventh Amendment ummunity in suits under the Equal Pay Act to have been a valid exercise of its Section 5 power. Sec Timmer v Michigan Dep't of Commerce, No. 95-1706, 1997 U.S. App. LEXIS 545 (Gth Cir Jan. 15. 1997) Two distnct courts have held that Congress's abrogation of the states' Eleventh Amendment ummunty under the Amencans with Disabilities Act (ADA) was a valid exeresse of its enforement power under the Founcenth Amendment. See Kaufman v. Carter, No. 1:95-CV-313, 1996 WL 731925 (W.D. Milch. Dec. 9, 1996). Mayer v. University of Minn., 940 F. Supp. 1474 (D. Minn 1996) (also finding abrogauon under Rehabilitation Act to be valid). Furthermore, an appellate court has found, notwithstanding Semunole Tribe. that Congress has the power to abrogate Eleventh Amendment immunity under us War Power See DiazGandia v. Dapena-Thompson, 90 F.3d 609. $616 \mathrm{n.9}$ (1st Cir. 1996) (upholding abrogation of Eleventh Amendment immunity in Veterans' Reemployment Rights Act); see also Krussman y Mlaryland. $935 \mathrm{~F}$ Supp. 659, 663 (D. Md. 1996) (reserving judgment on valudity of abrogatuon un Famuly and Mledical Leave Act); infra notes 278-82 (discussing Congress's abrogation of Eleventh Amendment immunty under patent and trademark laws).

103. See generally infra Section II.A.

104. 505 U.S. 144 (1992). Alternatuvely. one might say that the Supremacy Clause obligates the states to award such damages, but that no federal coun has the power to monitor the stite cours. complanse with this obligation. As discussed above, this is tantamount to an immunuty from labbilty 
It bears emphasizing that adoption of the immunity-from-liability interpretation of the Eleventh Amendment would not be a backhanded way of overruling what New York left of Garcia. It is important to distinguish three concepts: (1) the primary obligations imposed by the law; (2) the secondary or remedial obligations the law imposes in the event the primary obligation is violated; ${ }^{105}$ and (3) the jurisdiction of the lower federal courts. Garcia held that Congress could impose primary obligations on the states, such as the obligation to pay employees a minimum wage. Under the forum-allocation interpretation of the Eleventh Amendment, Congress possesses the power to subject states that violate those obligations to damage liability to aggrieved individuals. The immunity-from-liability interpretation of the Eleventh Amendment holds that Congress may not subject the states to such liability, but there are other ways to give efficacy to the states' primary obligations. First, individuals may sue state officials in their official capacities for prospective relief. ${ }^{106}$ Thus an individual who is aggrieved by a state's failure to pay him the required minimum wage could obtain a court order requiring the responsible state official to pay him the minimum wage. This order would comply with the Eleventh Amendment under current doctrine so long as the order required the official to pay wages that accrue after the court's order was entered. ${ }^{107}$ If the official violates that order, she would subject herself to contempt sanctions and, if the violation amounted to bad faith, the court would have the power to require the state itself to pay the unpaid amounts due under the court's order. ${ }^{108}$ This regime appears effective to ensure prospective compliance with an obligation, for example, to pay a minimum wage. ${ }^{109}$ To be sure, limiting the individual to prospective relief appears to give states the opportunity to avoid compliance for at least some period of time. But there are ways, short of subjecting the states to damage liability, to deter the states from even temporarily violating their obligation. Congress could, for example, subject states that violate the minimum wage obligation to a fine collectible by a federal agency. The Eleventh Amendment does not protect the states from suits by the United States. ${ }^{110}$ There may be other ways to give efficacy to the

105. On the distinction between primary and secondary obligations, see Carlos Manuel Vázquez, Treaty-Based Rights and Remedies of Individuals, 92 CoLUM. L. REV. 1082, 1089-90 \& n.26 (1992).

106. See Seminole Tribe v. Florida, 116 S. Ct. 1114, 1131 n.16 (1996).

107. See Edelman v. Jordan, 415 U.S. $651,668-69$ (1974) (affirming order requiring state official to comply with federal obligation to pay money to individuals from state funds, insofar as order required payment of amounts that accrued after entry of court's order).

108. See Hutto v. Finney, 437 U.S. 678, 691-92 (1978). But cf. infra text accompanying note 443 (noting that adoption of immunity-from-liability interpretation of Eleventh Amendment may protect states from contempt sanctions and costs where official has violated court order requiring prospective compliance with duty imposed by Congress under Article I).

109. By "prospective" in this context, I mean from the time of the court's order forward.

110. See supra text accompanying note 48 . The Court has held that states may not, consistently with the Eleventh Amendment, maintain parens patriae actions against sister states. See Hawaii v. Standard Oil Co., 405 U.S. 251, 258 n.12 (1972); New Hampshire v. Louisiana, 108 U.S. 76, 90-91 (1883). If this principle extends to the federal government as well, then there may be Eleventh Amendment problems with 
underlying federal obligation. ${ }^{111}$ Congress might make waiver of Eleventh Amendment immunity a condition of participation in some related federal program. ${ }^{112}$ What I have said, however, is sufficient to show that interpreting the Eleventh Amendment as an immunity from liability is not tantamount to denying Congress the power to regulate the states as permitted by Garcia and New York.

The immunity-from-liability interpretation of the Eleventh Amendment would, however, limit in an important way Congress's options for giving efficacy to the obligations it imposes on the states vis-à-vis individuals. It would eliminate (or at least place significant obstacles in the way of) perhaps the most effective, and certainly the most straightforward, method of enforcing those obligations: private lawsuits for damages by aggrieved individuals against the state itself. It is true that even the narrower, forum-allocation interpretation of the Eleventh Amendment places a potentially awkward obstacle in the way of such lawsuits: They must be brought in the state courts as an initial matter, with federal court involvement available only on appeal. But at least this option would remain available to Congress under the form-allocation interpretation, whereas it would be unavailable under the immunity-fromliability interpretation unless Congress could secure a waiver of immunity under a Spending Clause program. It is also true that even if the Eleventh Amendment were merely a forum-allocation principle, Congress might prefer to devise a scheme to procure a waiver of the immunity and thus permit suits

\footnotetext{
a regime in which a federal agency obtains fines aganst states that volate federal obligations towards individuals, and then turns over the fines to the aggneved individuals. One scholar has argued that Congress does have the power to turn over the proceeds to the injured individuals. and that Congress may even authorize the individuals to sue the states in a qui tam action on behalf of the U.S. government, and pertaps even to sue the states in their own names. See Jonathan R. Siegel. The Hidden Souree of Congress's Pow er to Abrogate State Sovereign Immunin: 73 TEX. L. REv. 539 (1995). The Court's opinion in Blatchiord v Native Village of Noatak throws cold water on (at least) the latuer two suggestions See 501 U.S 775.785 (1991) (expressing "doubt" that United States's power to suc states can be delegatal even to persons on whose behalf the United States itself might sue"). The water was thrown before the arguments were mate. but the author did not consider it too cold. See Siegcl, supra. at 568

111. See, e.g., Siegel, supra note 110, at 564-69 (proposing that indrviduals use qui tam actuons to enforce their own rights in place of U.S. government). In Par VI. I discuss Congress's power to authonze individuals to obtain damages from state officials responsible for volatuons of federal statutes

112. See South Dakota v. Dole, 483 U.S. 203 (1987) (upholding congressional use of spending power to "encourage" states to impose minimum drinking age). With regard to thus condiltoning power, Judge Frank Easterbrook has stated that Congress "has the whip hand in all of this " For example. Congress can wield its 'conditioning power,' tying a state's recelpt of federal money to th promise not to ininnge copyrights." Constitutional Law Scholars Anempt to Distill Recent Supreme Courn Term. 65 L.S L W 2274. 2288 (1996). Easterbrook mistakenly assumes here that Semuole Tribe denies Congress the power to make the copyright laws applicable to the states, however. At most. Semnole Tribe denies Congress the power to make states liable in damages for infringing copynghts. Thus misconception may explaun Easterbrook's further statement that Seminole Tribe is incompatible with Garcta See id.

It has been suggested that in light of its recent holding in United Stases $y$ Lopes. $115 \mathrm{~S} \mathrm{Cl} 1624$ (1995), the Cour should scale back Congress's power to induce states to act under the Spending Clause in circumstances in which Congress could not require the states to act under ts other enumerated powers See Lynn A. Baker, Conditional Federal Spending Afier Lopez, 95 CollM L REV 1911. 1916 (1995) If the Court does so, then the option noted in the text accompanying this footnote may become less promising than under current doctrine.
} 
in federal court. Whichever way the matter is analyzed, however, determining whether the Eleventh Amendment confers only an immunity from the original jurisdiction of the federal courts or also an immunity from liability will be important to Congress in determining how to respond to the recent decision in Seminole Tribe.

The issue has already attracted the attention of litigants, ${ }^{113}$ and it should soon attract Congress's attention. ${ }^{114}$ At issue is the efficacy with respect to the states of such generally applicable laws as those prohibiting copyright and patent infringement. Does Seminole Tribe mean that Congress may not allow copyright holders to sue state agencies that infringe their copyrights for damages in federal court (absent waiver), and thus that copyright holders would be relegated to a remedy in state court (if Congress should authorize one), subject to Supreme Court review? Or does it mean that Congress may not give copyright holders a right to obtain damages in any court from state agencies that infringe their copyrights? I will discuss in Part IV what Seminole Tribe suggests on that question, but first I shall discuss what recent preSeminole Tribe cases suggested.

\section{PRE-SEMINOLE TRIBE SUPPORT FOR READING THE ELEVENTH AMENDMENT AS MERELY A FORUM-ALLOCATION PRINCIPLE}

Readers of the Supreme Court's Eleventh Amendment opinions before Seminole Tribe would certainly have had grounds to conclude that the Court had definitively rejected what I have called the immunity-from-liability interpretation of that Amendment. Not only did a number of those opinions state broadly that the Amendment has no application in state courts, ${ }^{115}$ but the Court also unanimously ruled that the Eleventh Amendment does not limit the Supreme Court's appellate jurisdiction. ${ }^{116}$ It found that certain federal constitutional and statutory provisions impose damage liabilities on states, and it held that the Supremacy Clause requires the states to entertain suits seeking such damages in their own courts. ${ }^{117}$ In this Part, I review the indications in the pre-Seminole Tribe cases that the Court has viewed the Amendment as bearing only on original federal jurisdiction-that the Amendment, in other words, does not have any bearing on whether states are liable to individuals

113. See Victoria Slind-Flor, High Court Gambling Case May Give States Big Payoff. NAT’L L.J., July 8,1996 , at B1.

114. See Letter from Jonathan R. Siegel, Associate Professor, George Washington Univ., to Betty Wheeler, Democratic Counsel, Courts \& Intellectual Property Subcomm., Judiciary Comm., U.S. House of Representatives (Apr. 12, 1996) (on file with author).

115. See, e.g., Will v. Michigan Dep't of State Police, 491 U.S. 58, 63-64 (1989); Maine v. Thiboutot, 448 U.S. 1, 9 n.7 (1980); Nevada v. Hall, 440 U.S. 410, 420-21 (1979).

116. See infra text accompanying notes 123-27.

117. See infra text accompanying notes 144-51. 
for damages, but merely requires that any federal liability of the states toward individuals be enforced in the state courts, subject to review in the Supreme Court.

\section{A. Cases Recognizing a Constitutional Obligation of States to Afford Monetary Relief to Individuals in Their Own Courts}

Authority for the proposition that the Eleventh Amendment does nothing more than confer an immunity from the original jurisdiction of the federal courts can be found in the cases in which the Supreme Cour appears to have recognized that the Constitution itself in certain circumstances requires the states to afford monetary relief to private individuals. These cases indicate that if the states do not afford that relief voluntarily, individuals are entitled by the federal Constitution to maintain an action against the states in the state courts, and the Supreme Court may review the state courts' decisions to ensure that those courts have enforced the states' constitutional obligation to afford the required relief. These cases indicate that neither the Eleventh Amendment nor the states' own law of sovereign immunity may be interposed to avoid such a suit, and that the Eleventh Amendment similarly does not bar Supreme Court review of the state courts' decisions.

Perhaps surprisingly, the Court has found a right of individuals to damages from the states in only two provisions of the Constitution. One of them is the Takings Clause of the Fifth Amendment, made applicable to the states through the Fourteenth Amendment. This is one of the few constitutional provisions that expressly addresses issues of liability. It provides that "private property [shall not] be taken for public use, without just compensation." 118 The Supreme Court has held that "a landowner is entitled to bring an action in inverse condemnation as a result of "'the self-executing character of the constitutional provision with respect to compensation."."119 The Court has indicated that this remedy is available in the state courts even if there is no state statute that authorizes it. ${ }^{120}$ Nor may the state courts interpose their own law of sovereign immunity to bar such claims. ${ }^{121}$ The Eleventh Amendment is not regarded as a bar to Supreme Court review of inverse condemnation

118. U.S. CONST. amend. V.

119. First English Evangelical Lutheran Church v. County of Los Angeles, 482 U.S. 304. 315 (1987) (quoting United States v. Clarke, 445 U.S. 253. 257 (1980) (quoung 6 P. NICHOLS. ENINEIT DOMLAN $\S$ 25.41 (3d rev. ed. 1972))).

120. See id. (citing San Diego Gas \& Electric Co. v. City of San Diego, 450 U.S. 621. 654-55 (1981) (Brennan, J., dissenting)).

121. See id. at 316 n.9 (rejecting Solicitor General's argument that "prnnciples of sovereign immunity [help] ... establish[] that the [Fifth] Amendment itself is ... not a remedial proviston"). 
actions from the state courts raising takings issues under the Fifth and Fourteenth Amendments. ${ }^{122}$

The other constitutional provision that the Court has held sometimes requires the states to afford monetary relief to individuals is the Due Process Clause. The relevant holdings have come in tax refund cases in which the Court has held that if a state does not offer taxpayers an opportunity to challenge the lawfulness of a tax before paying it, then the state must give the taxpayer a postpayment hearing to determine the tax's validity and, if the tax turns out to have been invalid, a refund of the tax or some other remedy that would cure the violation. ${ }^{123}$ The Court's clearest recent articulation of this principle came in McKesson. The McKesson principle appears to require the state itself to provide persons a damage remedy whenever it deprives them of liberty or property without giving them a predeprivation hearing and the deprivation turns out to have been in violation of state law. I consider this issue below. ${ }^{124}$ For the moment, we may assume that the principle applies only in cases involving state deprivations of property that are challenged as violating federal law. What is important is that the Court recognized that the Constitution requires the state to confer a refund if the deprivation was invalid and no other remedy would cure the violation, and that the state may not interpose its own law of sovereign immunity to bar a lawsuit seeking such a remedy. ${ }^{125}$ The defendant in McKesson was a state agency, and the Court's opinion appears to hold that the Due Process Clause requires a damage remedy from the state itself. ${ }^{126}$ As discussed above, the Court also reaffirmed in McKesson that the Eleventh Amendment does not protect the states from Supreme Court review of tax refund cases brought initially in the state courts. ${ }^{127}$

There is language in McKesson, however, that may cast doubt on whether the case in fact stands for the broad propositions just stated. In describing its Eleventh Amendment holding, the Court stated that "when a state court takes

122. See Jack M. Beermann, Government Official Torts and the Takings Clanse: Federalism and State Sovereign Immunity, 68 B.U. L. REv. 277, 337 (1988). The Eleventh Amendment does, however, bar individuals from maintaining takings claims against states in the lower federal courts. See John G. \& Marie Stella Kenedy Mem'l v. Mauro, 21 F.3d 667, 674 (5th Cir. 1994); McMurtray v. Holladay, 11 F.3d 499. 504 (5th Cir. 1993).

123. If the tax is invalid because discriminatory, the state may be able to cure the violation by collecting more taxes from the previously favored parties. If the state does so, it may not be required to provide a refund to the disfavored party. See McKesson Corp. v. Division of Alcoholic Beverages \& Tobacco, 496 U.S. 18, 39-41 (1990). If the tax was invalid because the state lacked the power to impose it, the state is required to provide a refund. See id. at 39; Ward v. Board of County Comm'rs, 253 U.S. 17, 24 (1920).

124. See infra text accompanying notes 421-27. See generally Fallon \& Meltzer, supra note 16, at 1826 (suggesting that McKesson applies only to tax refund cases).

125. The Court made the latter point clear in Reich v. Collins, 115 S. Ct. 547, 549 (1994).

126. See McKesson, 496 U.S. at 22; see also American Trucking Ass'n, Inc. v. Smith, 496 U.S. 167, 182-83 (1990).

127. See McKesson, 496 U.S. at 26-31. 
cognizance of a case, the State assents to appellate review by this Courn of the federal issues raised in the case." 128 This suggests that if the state refuses to take cognizance of the case by, for example, invoking its own law of sovereign immunity, the Supreme Court's appellate jurisdiction would be defeated. This interpretation is in substantial tension, to say the least, with the Court's due process holding. The Court held that the Due Process Clause requires the states to afford a hearing and award a monetary remedy if the hearing discloses the tax to have been illegal. A state that denies a remedy on the ground of sovereign immunity is not in any meaningful sense offering a postdeprivation hearing, let alone the required postdeprivation remedy. In Reich $v$. Collins, ${ }^{129}$ the Court, again unanimously, made it clear that the state is not free to deny the constitutionally required damage remedy by invoking its own law of sovereign immunity. ${ }^{130}$ Is it conceivable that the Court meant that the Due Process Clause prohibits the state from invoking its sovereign immunity law to deny a hearing and a remedy, but that if the state (illegally) does so, the Supreme Court for that very reason lacks appellate jurisdiction? That would certainly be a problematic holding, one that would effectively gut the supposed "obligation" to provide a hearing and remedy. I shall accordingly interpret McKesson as permitting the Supreme Court to review state court decisions denying the remedy required by the Due Process Clause even if the state does not consent.

The takings and tax refund cases appear to establish that in certain circumstances the Constitution itself obligates the states to confer a retrospective monetary remedy to private individuals. ${ }^{131}$ In those circumstances, the Eleventh Amendment requires that the remedy be sought initially in the state courts, ${ }^{132}$ but the Supremacy Clause obligates the state courts to entertain actions seeking the remedy and to award the remedy. State

128. Id. at 30 .

129. 115 S. Ct. 547.

130. See id. at 549 .

131. A third constitutional provision that may itself require the states to entertan private damage actions against themselves may be the Full Faith and Credil Clause, U.S. Co.ssT. art. IV. $\$$ 1. In Nevada v. Hall, 440 U.S. 410, 426-27 (1979), the Court held that Califomia was free to subject the state of Nevada to a private suit in the California courts and to apply its law to hold the state liable for an aceident caused by a Nevada official on California roads. If the plantiff in such an action recovers a judgment. does the Full Faith and Credit Clause require the courts of Nevada (or any other state in which Nevada has assets) to enforce the money judgment? The Cour has not addressed the issue, but if the answer is yes. then this would be another example of a constitutional provision that obligates the siates to pay money to individuals that would be enforceable in the state courts and, if the forum-allocation interpretation of the Eleventh Amendment is correct, in the U.S. Supreme Cour on appeal. If the immunity-from-liability interpretation is correct, then the Supreme Court would be powerless to enforce this obligation against a recalcitrant state. This, in my view, would be tantamount to holding that the Full Faith and Credit Clause does not in fact require the states to enforce the money judgments entered against states by sister states on state law causes of action.

132. See Reich, 115 S. Ct. at 549 (recognizing that Due Process Clause requires state to confer monetary relief to individuals, but noting that Eleventh Amendment "does generally bas tax refund claums from being broughi [against the states in federal cour]"): see also supra note 122. 
law of sovereign immunity may not be interposed to bar such a claim. The Supreme Court through its appellate jurisdiction may monitor the state courts' compliance with their obligations under the Supremacy Clause. These cases thus support the conclusion that the Eleventh Amendment is merely a forumallocation principle.

\section{B. Cases Involving Statutes That Impose a Liability on States Without Abrogating Eleventh Amendment Immunity}

The cases recognizing that the federal Constitution in certain circumstances obligates the states to pay money damages to individuals could perhaps be regarded as a limited exception to an Eleventh Amendment interpretation that gives states an immunity from federal liability. On this theory, the states' immunity from liability and suit simply does not apply with respect to those few constitutional provisions that themselves make states liable in damages to individuals, but it does preclude Congress from subjecting the states to damage liability by statute. Whatever the theoretical plausibility of that position, ${ }^{133}$ it is flatly contradicted by recent pre-Seminole Tribe cases that interpret federal statutes to impose an obligation on states and to subject states to monetary liability to individuals aggrieved by violations of the obligation, but not to abrogate the states' Eleventh Amiendment immunity.

As discussed above, the Garcia decision held that the Tenth Amendment did not preclude Congress from making the FLSA applicable to the states. Congress expressly extended the substantive protections of that Act to certain state employees in 1966. ${ }^{134}$ In Employees of the Department of Public Health \& Welfare v. Department of Public Health \& Welfare, ${ }^{135}$ the Court considered whether the 1966 amendments to the FLSA also subjected states that violate those provisions to suits for damages by their employees. The majority opinion by Justice Douglas left that question open, ${ }^{136}$ but Justice Marshall's opinion concurring in the result (joined by Justice Stewart) concluded that the amendments clearly contemplated private damage suits against the states. ${ }^{137}$ Marshall went on to note, however, that the Eleventh Amendment protected the states from being sued in federal court. He wrote:

133. As discussed in Part IV, the McKesson holding that a state is required to supply a damage remedy when it illegally deprives persons of liberty or property without a prior hearing is tantamount to a holding that Congress has the power to subject states to damage liability whenever it has the power to impose primary obligations on the states under Article I.

134. See 29 U.S.C. $\$ 203(\mathrm{e})(2)(\mathrm{C})(1994)$.

135. 411 U.S. 279 (1973).

136. See id. at 287 . The majority noted that even in the absence of private damage actions, the substantive provisions of the Act could be enforced against the states by the Secretary of Labor. See id. at 286.

137. See id. at 297 n.12 (Marshall, J., concurring in result). 
While constitutional limitations upon the federal judicial power bar a federal court action by these employees to enforce their rights, the courts of the State nevertheless have an independent constitutional obligation to entertain employee actions to enforce those rights. . . Thus, since federal law stands as the supreme law of the land, the State's courts are obliged to enforce it, even if it conflicts with state policy. ${ }^{138}$

Justice Marshall's reasoning became the basis for the majority's response in Atascadero State Hospital v. Scanlon ${ }^{139}$ to a criticism raised (ironically) in a dissenting opinion in which Marshall concurred. At issue in Alascadero was whether Congress had abrogated the states' Eleventh Amendment

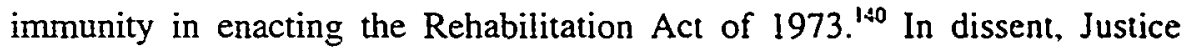
Brennan stressed indications in the statutory text and legislative history that Congress had intended to make the substantive requirements of the Rehabilitation Act applicable to the states, and he described the majority's holding that the states were protected by the Eleventh Amendment as tantamount to "exempting the States from compliance with laws that bind every other legal actor in our Nation." "|s1 Justice Powell's majority opinion accused the dissent of misperceiving the issue. Powell quoted Marshall's statement in Employees that "the issue is not the general immunity of the States from private suit . . but merely the susceptibility of the States to suit before federal tribunals." 142 The majority went on to say that "[i]t denigrates the judges who serve on the state courts to suggest that they will not enforce the supreme law of the land."143

In Employees and Atascadero, the language that supports the forumallocation interpretation of the Eleventh Amendment appeared in concurring opinions or was dictum. ${ }^{144}$ That dictum became holding with the Court's

138. Id. at 298 (Marshall, J., concurring in result) (cttations omitted).

139. 473 U.S. 234 (1985).

140. Id. at 235 .

141. Id. at 248 (Brennan, J., dissenting).

142. Id. at 240 n.2 (quoting Employees, 411 U.S. at 293-94 (Mlarshall. J., concumng in result) (emphasis added)).

143. Id. The Atascadero Cour's conception of Eleventh Amendment immunity as an immunity from the jurisdiction of the lower federal courts is shown further by its insistence that a waiver of that immunity cannot be inferred merely from a state statute or constitutional provision in which the state consenis to be sued by private individuals. To count as a waiver of Eleventh Amendment immunity. the statute or constitutional provision must specify that the state consents to be sued in federal court. A general consent to suit will be construed, the Coun said, as a consent to be sued in state courc. See id. at 241; see also Ford Motor Co. v. Department of Treasury, 323 U.S. 459, 465 (1945): Great N. Life Ins. Co. v. Read. 322 U S 47, 54 (1944); Smith v. Reeves, 178 U.S. 436, 441 (1900). These cases are not inconsistent with the immunity-from-liability interpretation, however. The immunity-from-liability interpretauon masntans that the Eleventh Amendment is both an immunity from jurisdiction and an immunity from lability. If He apply a clear statement rule to both immunities, then it would be appropriate to hold that the stales are suable in federal courts only if Congress has clearly made them suable in federal coun. If the state is not amenable to suit in federal court, the question of its immunity from liability arises only in state court actons.

144. The language from Atascadero may indeed nol count as full-fiedged suppon for the forumallocation interpretation. Justice Powell recognized that the state courts were obligated to enforce federal 
recent decision in Hilton v. South Carolina Public Railways Commission. ${ }^{145}$ In that case, the Court reaffirmed on stare decisis grounds the holding of Parden v. Terminal Railway of Alabama Docks Department, ${ }^{146}$ that the Federal Employers' Liability Act (FELA) subjected the states to monetary liability to individuals. ${ }^{147}$ In Welch v. Texas Department of Highways \& Public Transportation, ${ }^{148}$ however, the Court overruled Parden's additional holding that FELA abrogated the states' Eleventh Amendment immunity. ${ }^{149}$ The upshot is that FELA imposes a monetary liability on states which, because of the Eleventh Amendment, can be enforced only in state courts. The Court affirmed in Hilton that " "the Eleventh Amendment does not apply in the state courts," 150 and that "when ... a federal statute does impose liability upon the States, the Supremacy Clause makes that statute the law in every State, fully enforceable in state court."151

\section{SEMINOLE TRIBE AND THE CASE FOR AN IMMUNITY-FROM-LIABILITY INTERPRETATION OF THE ELEVENTH AMENDMENT}

Given the clarity with which the Court had appeared to embrace the forum-allocation interpretation of the Eleventh Amendment, many observers were surprised to find indications in the Seminole Tribe majority opinion that

laws, but he did not say that the Supreme Court would have jurisdiction to review state court decisions in suits against states. The Atascadero footnote may therefore be consistent with a view of the Eleventh Amendment as permitting Congress to impose liabilities on the states dependent for their efficacy on the state courts without Supreme Court review. (Such an interpretation would be consistent with Powell's expression of confidence in the state courts' ability and willingness to enforce federal law faithfully.) As noted above, however, someone who agrees with Chief Justice Marshall's more realistic appraisal in Osborn v. Bank of the United States, 22 U.S. (9 Wheat.) 738 (1824), of state court willingness to enforce their own obligations without monitoring by a federal court would question whether such liabilities are in fact legal ones. Justice Marshall's opinion in Employees does not refer explicitly to the Supreme Court's power to review state court decisions denying a required federal remedy, but his citation of Testa $\mathrm{v}$. Katt, 330 U.S. 386 (1947), and General Oil Co. v. Crain, 209 U.S. 211 (1908), suggests strongly that he assumed that such review would be available. See Employees, 411 U.S. at 298 (Marshall, J., concurring in result).

145. 502 U.S. 197 (1991).

146. 377 U.S. 184 (1964).

147. See Hilion, 502 U.S. at 206-07.

148. 483 U.S. 468 (1987).

149. See id. at 478. The issue in Welch was whether the states' Eleventh Amendment immunity was abrogated by the Jones Act, but the Jones Act incorporates the remedial scheme of FELA and the Court in both Welch and Hilton assumed that the issue would be resolved the same way under both statutes. See Hilton, 502 U.S. at 204 n.2; Welch, 483 U.S. at 495 (White, J., concurring).

150. 502 U.S. at 205 (quoting Will v. Michigan Dep't of State Police, 491 U.S. 58, 63-64 (1989)).

151. Id. at 207. The Court cited for this proposition Howlett v. Rose, 496 U.S. 356, 367-68 (1990), thus indicating that state law principles of sovereign immunity cannot bar such a state court action. Howlett was an action brought against a school board in the state courts under section 1983. The state court had dismissed the suit on sovereign immunity grounds, but the Supreme Court reversed, holding that a sovereign immunity defense is unavailable in a federal action to a defendant that is not immune from suit under state law in analogous state law actions. See id. at 375. In Hilton, the Court appears to have read Howlett to establish the broader proposition that state law sovereign immunity defenses cannot be interposed to bar from the state courts validly imposed federal liabilities. 
the Court embraces an immunity-from-liability construction of the Amendment. The indications are all the more surprising because of the importance the Court's principal holding gives to this issue. Whatever the nature of the immunity conferred by the Eleventh Amendment, the Cour established in Seminole Tribe that it may not be abrogated by Congress pursuant to Article I.

The statements in Seminole Tribe suggesting that the Court now rejects the forum-allocation view might perhaps be dismissed as dictum. Certainly, the points did not appear to be central to the Cour's reasoning. Even if dictum, however, they are important because of what they tell us about how the Justices in the majority think about Eleventh Amendment issues. Moreover, as I shall explain, there is a sense in which the Court's entire treatment of the Eleventh Amendment might be regarded as dictum.

The Seminole Tribe sued Florida and its Governor in federal court seeking an order requiring the State to negotiate in good faith with the Tribe over gaming rights, as the Indian Gaming Regulatory Act (IGRA) required the State to do. ${ }^{152}$ IGRA included an express statutory abrogation of the states' Eleventh Amendment immunity, and the Court's principal holding in the case was that the suit against the State had to be dismissed because the abrogation of Eleventh Amendment was unconstitutional. ${ }^{153}$ As noted earlier, the Cour reaffirmed its holding that Eleventh Amendment immunity may be abrogated pursuant to the Fourteenth Amendment, but it reversed Union Gas's holding that such abrogation could be accomplished pursuant to "antecedent" constitutional provisions. ${ }^{154}$ It is curious that this holding came in a case seeking only injunctive relief. Because prospective injunctive relief may be obtained under Ex parte Young in a suit against state officials without running afoul of the Eleventh Amendment, the Court's Eleventh Amendment holding came in a case in which the Amendment's impact was purely formal. An Eleventh Amendment holding that will have its primary substantive impact on suits seeking damages from the state was thus rendered in a case in which damages were not at'stake.

Because the Tribe had sued the Governor as well as the State, the Court had to do some fancy footwork even to reach the Union Gas issue. Had the Court sustained the suit against the Governor, the need to determine whether the suit against the State should be dismissed would have evaporated. The Court could perhaps have gone on to consider whether a suit against the state seeking the same relief could be maintained even after finding that the relief could be sought against the Governor, but reversing Union Gas where nothing at all turned on it would have seemed too much like an advisory opinion, even

152. See Seminole Tribe v. Florida, 116 S. C. 1114, 1119 (1996).

153. See id.

154. See id. at 1127-28. 
if technically it may not have been one. But dismissing the suit against the Governor required some doctrinal gymnastics. The Court held that the suit against the Governor could not be maintained because IGRA authorized only a suit against the State and placed certain limits on what the court could order. ${ }^{155}$ The Court concluded that permitting the Tribe to obtain injunctive relief against the Governor would be incompatible with the finely-honed remedial scheme Congress had set up when it enacted IGRA. ${ }^{156}$ The principle the Court applied in dismissing the suit against the Governor-that an injunctive remedy against a state official is unavailable to enforce a statute if Congress in enacting the statute set up an enforcement mechanism that is incompatible with such a remedy-is unexceptionable. Indeed, the Court had established such a rule with respect to suits under section $1983,{ }^{157}$ and it would have been extraordinary had the Court found an injunctive remedy to be available independently of section 1983 where the same remedy would be unavailable under section 1983 because incompatible with the statute establishing the right. What is difficult to understand is the Court's conclusion that the injunctive remedy the Tribe sought against the Governor would have been inconsistent with the remedial scheme established in IGRA. First, it is a stretch to say that IGRA contemplated only suits against the State. ${ }^{158}$ Even assuming it did, the Court struck this provision down because suits against the state violate the Eleventh Amendment. How can a suit against the Governor seeking the very same relief be said to be incompatible with the scheme Congress set up? The Court said it was incompatible because IGRA did not authorize a court order requiring compliance with the obligation to negotiate in good faith, but authorized only specific steps the court could take in response to the State's failure to comply. ${ }^{159}$ But the Tribe did not seek in the suit against the Governor anything more than it could have gotten in its suit against the State, ${ }^{160}$ and the Court did not explain why permitting a suit seeking that limited form of relief to go forward would be incompatible with IGRA's remedial scheme. At any rate, the Court made it clear that the problem, such as it was, was statutory. It recognized that the Eleventh

155. Specifically, the court could not require the State to negotiate in good faith; it could only refer the matter to a mediator if the State refused to negotiate, and if no agreement was reached after a certain period of time, the matter would be referred to the Secretary of the Interior. See id. at 1120.

156. See id. at 1131-33.

157. See Middlesex County Sewerage Auth. v. National Sea Clammers Ass'n, 453 U.S. 1, 13-18 (1981).

158. The statute does not specifically provide that the suit must be brought against the state, as opposed to its officials. Its jurisdictional provision merely states that the district courts shall have jurisdiction over "any cause of action initiated by an Indian tribe arising from the failure of a State to enter into negotiations with the Indian tribe . . ." 25 U.S.C. $\$ 2710$ (d)(7)(A)(i) (1994). The Court's construction of this language as requiring that the suit be brought against the state, as opposed to its officials, appeared to contravene the well-known maxim that statutes are to be construed where possible so as to avoid constitutional problems. See NLRB v. Catholic Bishop, 440 U.S. 490, 504-07 (1979).

159. See Seminole Tribe, $116 \mathrm{~S}$. Ct. at 1120.

160. See Jackson, supra note 15. 
Amendment would not prevent Congress from authorizing a suit against the Governor for the limited relief IGRA contemplated in a suit against the State. ${ }^{161}$

The mess the Court made of Ex parte Young doctrine in Seminole Tribe is not the focus of this Article. ${ }^{162}$ I have discussed it to the extent that I have to suggest that even the principal holding of the case shares an important feature of obiter dicta: It was rendered in a case whose facts did not squarely present the issue. At the very least, it was rendered in a case involving a form of relief that was unavailable in the case, at best, because of a gross drafting error on Congress's part. Relatedly, the Court's tortured reasoning in the $E r$ parte Young part of the opinion showed its eagerness to take liberties to accomplish quick doctrinal change in this area. For these reasons, technical distinctions between holding and dicta seem to be out of place in examining the Court's opinion. ${ }^{163}$

\section{A. Indications in Seminole Tribe of a Shift to the Immunity-from-Liability Interpretation}

In summing up its holding overruling Union Gas, the Court in Seminole Tribe stated that "[e]ven when the Constitution vests in Congress complete lawmaking authority over a particular area, the Eleventh Amendment prevents congressional authorization of suits by private parties against unconsenting states."164 The Court's failure to limit that statement to suits in the federal courts, suggesting that Congress lacks the power to authorize suits against the states enforceable in state courts, may just have been an oversight. Yet there are further indications in the Seminole Tribe opinion that the majority in that case regarded Eleventh Amendment immunity as immunity from liability, not just from federal jurisdiction, and thus understood its holding as a holding that Congress may not subject states to liability to private individuals pursuant to Article I powers. Admittedly, the suggestions are subtle and may refiect nothing more than sloppy drafting or a failure to think through the issues. It

161. See $116 \mathrm{~S}$. Ct. at 1132-33. The Cour did not decide whether the obligations IGRA imposed on the states comported with the constitutional limitations the Cour enunciated in New York $v$ : United States. Thus it is certainly not clear that a statute obligating the Govemor to negouste in good fath would be constitutional. See infra note 305 and accompanying text. But such a statute would not volate the Eleventh Amendment.

162. On this subject, see Jackson, supra note 15.

163. In his dissenting opinion, Justice Stevens offers another, very different reason for regarding the majority's treatment of the Eleventh Amendment as dictum. The funcuons that IGRA requires the federal courts to perform, he maintains, are not "judicial" functions withn the meaning of Article III. because the courts' "dispensible involvement [comes] in the intermediate stages of a procedure that begins and ends in the Executive Branch." Seminole Tribe, 116 S. Ct. at $1144-45$ (Stevens. J.. dissentung); see also infro note 305 and accompanying text (discussing whether IGRA is unconstututional. because 1 commandeers states in violation of New York v: United States).

164. $116 \mathrm{~S}$. Ct. at 1131 . 
is possible, however, that the evidence to which I shall point reflects a shift towards a conception of the Eleventh Amendment as an immunity from liability.

\section{The Seminole Tribe Court's Interpretation of Cohens}

As discussed above, the Court in McKesson said that the Eleventh Amendment does not limit the Supreme Court's appellate jurisdiction. This proposition is usually traced to the Court's decision in Cohens $v$. Virginia. ${ }^{165}$ Cohens was an action brought by the state of Virginia in its own courts against private individuals. The individuals lost in the state courts and appealed to the Supreme Court. The Court's Eleventh Amendment holding might be understood merely as a holding that a state waives its immunity when it initiates an action against an individual in state court, and that the Eleventh Amendment therefore does not bar an appeal to the Supreme Court from a judgment favoring the state. So construed, the Amendment could still bar an appeal to the Supreme Court in a case that was initiated in the state courts by the private party. The Court's opinion in Cohens appears to support such an interpretation. ${ }^{166}$ In McKesson, however, the Court acknowledged this ambiguity in Cohens and went on to note that the decision had come to be understood for the broad proposition that the Eleventh Amendment simply does not limit the Supreme Court's appellate jurisdiction. ${ }^{167}$

In light of this history, it is interesting to note the Seminole Tribe Court's interpretation of Cohens. The Court described the case as standing for the proposition that "this Court is empowered to review a question of federal law arising from a state court decision where a State has consented to suit."168 The Court's resurrection of the "consent" interpretation of Cohens casts doubt on the forum-allocation interpretation of the Eleventh Amendment. It suggests that if Congress subjects a state to monetary liability to individuals, a state may still interpose a state law defense of sovereign immunity to bar the action in state courts, and, if the state thus signals its lack of consent to the suit, the U.S. Supreme Court would lack the power to review any state court decision. Although in theory perhaps the state courts would remain bound by the Supremacy Clause to afford the federal remedy, in practice there would be no way for a federal court to intervene should the state violate that obligation. The result is that the states may effectively immunize themselves from federal liabilities.

165. 19 U.S. (6 Wheat.) 264 (1821).

166. See generally Jackson, supra note 1, at 19-25.

167. See McKesson Corp. v. Department of Alcoholic Beverages \& Tobacco, 496 U.S. 18, 27 (1990) (citing General Oil Co. v. Crain, 209 U.S. 211, 233 (1908) (Harian, J., concurring)).

168. $116 \mathrm{~S}$. Ct. at $1131 \mathrm{n} .14$ (emphasis added) (citation omitted). 
As noted above, the "consent" language the Court employed in Seminole Tribe was also used by the Court in McKesson in describing its Eleventh Amendment holding. Yet as discussed above, McKesson itself holds that the Due Process Clause requires the states to provide a hearing and a damage remedy in certain circumstances, and this conflicts flatly with the idea that a state is free to interpose its own law of sovereign immunity to deny the required remedy. Reich $v$. Collins confirms that the state may not do so. ${ }^{169}$ It would certainly be odd to say that an unlawful invocation of sovereign immunity is nevertheless effective to defeat the Supreme Cour's appellate jurisdiction. Such an interpretation of McKesson likewise would be inconsistent with the Court's holding in General Oil Co. v. Crain, ${ }^{170}$ on which the McKesson Court also relied. In Crain, the state court had relied on the state's own law of sovereign immunity in refusing to entertain a suit secking an injunction, ${ }^{171}$ but the Supreme Court ruled that the state-law sovereign immunity did not deprive it of jurisdiction to review the case. ${ }^{172}$

Given that the main thrust of the McKesson opinion was that the states were required to provide certain remedies, a reader might be forgiven for taking Justice Brennan's reference to the states' "assent" as a reference to some form of constructive assent. Perhaps Justice Brennan would say that a state "assents" to a suit against it by taking cognizance of the case even if the suit is dismissed at the outset on sovereign immunity grounds. If so, then a state effectively assents to Supreme Court review of cases against it by having a system of courts that allows the filing of claims by individuals. ${ }^{173}$ (Justice Brennan argued forcefully in a number of cases that the states should be deemed to have waived their immunity from private claims in federal court by ratifying the Constitution. ${ }^{174}$ ) Chief Justice Rehnquist's reference to "consent" as a condition of the Court's appellate jurisdiction over suits against the states is no doubt a reference to a more robust understanding of that

169. See 115 S. Ct. 547,549 (1994) (holding that state courts must give effect to federal statute imposing liability on state, notwithstanding "the sovereign immunity. States traditionally enjoy in thear own courts").

170. 209 U.S. 211 (1908).

171. See id. at 216

172. See id. at 228 .

173. Indeed, a state would probably be deemed to have assented to suits agaunst it on this theory even if its court system did not permit the filing of claims by individuals. Vicki Jackson mantauns that "[t]he mere existence of the state cour of general jurisdiction to which a claim aganst the state might be presented, even absent the state's consent to be sued, has justified the Supreme Court's assention of constitutional obligations to provide remedies against the state." Jackson. supra note 1. at 38. but she goes on to recognize that "to the extent consent refers to the mere existence of a state courn system. the concept no longer seems aptly captured by the word "consent." $i d$. at 39 . For a discussion of the cases cited by Jackson for the first proposition, see infra note 390 .

174. See, e.g., Pennsylvania v. Union Gas Co., 491 U.S. 1. 19-20 (1988) (arguing that states. by ratifying Constitution, relinquished immunity where Congress found it necessany under Commerce Clause to render them liable); Parden v. Terminal Ry.. 377 U.S. 184, 192 (1964) (same). 
term. ${ }^{175}$ As noted above, making the states' consent a condition of the Supreme Court's appellate jurisdiction over suits against them would be tantamount to an adoption of the immunity-from-liability interpretation of the Eleventh Amendment.

\section{Seminole Tribe's Prescriptions for Antitrust, Bankruptcy, Copyright, and Patent Claims Against the States}

If the Court's interpretation of Cohens had been the only hint in Seminole Tribe that the Court regarded Eleventh Amendment immunity as an immunity from liability, I could perhaps be accused of making too much of what may simply have been a careless description of precedent. ${ }^{176}$ Another portion of the Court's opinion, however, reinforces this interpretation.

In his dissenting opinion, Justice Stevens cited as a reason for rejecting the Court's abrogation holding the problems it would pose for the effective enforcement against the states of numerous federal statutes, including those relating to antitrust, patent, bankruptcy, and copyright. ${ }^{177}$ Federal courts have exclusive jurisdiction over suits to enforce those statutes. Thus, if Congress lacks the power to subject the states to private suits in federal court, no forum would exist for the enforcement of state obligations under these statutes. ${ }^{178}$ The majority described Justice Stevens's fears as exaggerated, ${ }^{179}$ but the two reasons the majority gave for this characterization are telling. First, it noted that prospective relief may be obtained in the federal courts for violation of these statutes under Ex parte Young. ${ }^{180}$ Second, it observed that the Court

175. Chief Justice Rehnquist does, however, say plainly that a state's consent to being sued in its own courts will automatically give rise to Supreme Court jurisdiction. The state is thus not free to consent to suit in its own courts while avoiding possible Supreme Court review of the resulting state court decision. On the possible justifications for this rule, see infra note 468. The state's freedom to withhold consent to suit in its own courts may be limited in certain respects by federal law. McKnett v. St. Louis \& San Francisco Railway, 292 U.S. 230 (1934), and related cases hold that the states' discretion to deny jurisdiction to their courts is limited by a nondiscrimination principle: States may not discriminate against rights based on federal law. See id. at 234. Scholars have argued that this principle means that states may not withhold their consent to be sued in their own courts under federal law if they have consented to be sued on analogous claims based on state law; at least one commentator has gone further and denied that states can withhold consent to be sued in their own courts in cases based on federal law if they have consented to be sued in their own courts in any type of case. See Massey, supra note 63, at 145-46. But see LAURENCE H. TRIBE, AMERICAN CONSTITUTIONAL LAW § 3-26, at 184 n.45 (2d ed. 1988); Fletcher, Historical Interpretation, supra note 7, at 1095 \& n.243. While the narrower limitation, prohibiting state refusals to consent if they have consented to similar suits under state law, may be plausible, the broader one cannot, I think, be reconciled with the statement in Seminole Tribe. Indeed, the proponent of this view uses this line of argument to argue that the forum-allocation view is correct. See Massey, supra note 63 , at 146.

176. That is, indeed, how I am inclined to take the similar statements of the Seminole Tribe dissenters and of Justice Kennedy in the Hess case. See infra text accompanying notes 220-26.

177. See Seminole Tribe v. Florida, 116 S. Ct. 1114, 1134 \& n.1 (1996) (Stevens, J., dissenting).

178. See id. (Stevens, J., dissenting).

179. See id. at 1131 n.16.

180. See id. 
has never held that the federal antitrust, copyright, or bankruptcy statutes authorize suits against the states. ${ }^{181}$ (The majority's second response ignored the problem its decision poses for patent laws, which Congress clearly has made applicable to the states and enforceable against them in private suits in federal court. ${ }^{182}$ ) What the majority glaringly omitted to say, however, is that Congress could easily alleviate the problem by giving the state courts jurisdiction over these suits. If it had viewed Eleventh Amendment immunity as an immunity from original federal jurisdiction only, the majority surely would have regarded state court suits under these statutes, subject to Supreme Court review, as an effective way to enforce these statutes insofar as they impose obligations on the states. Justice Stevens probably would not have regarded suits in the state courts as comparable to suits in the federal courts, but the Justices in the majority tend to have confidence in the state courts' ability and willingness to enforce federal law faithfully. That was indeed Justice Powell's point in Atascadero. It is true that with respect to these statutes, unlike the statute involved in Atascadero, Congress has made the judgment that only federal court enforcement will do. ${ }^{183}$ If the Eleventh Amendment precludes Congress's preferred scheme (as the Coun held in Seminole Tribe) then it is surely important that state court enforcement with Supreme Court review remains an option.

The majority's failure to mention this option in responding in a footnote to a point made by a dissent is not, to be sure, weighty authority for the proposition that the Court now regards the Eleventh Amendment as establishing an immunity from liability. Certainly, someone litigating before the Court would not be well advised to cite this footnote for that proposition. But I do think that this omission is important for what it tells us about the majority's mindset when it comes to the Eleventh Amendment. A Justice who, in considering the Eleventh Amendment, thinks of the forum-allocation principle that some believe the Amendment to be-a Justice who regards the Eleventh Amendment as establishing nothing more than that someone who has a claim against a state must litigate that claim initially in state court and may seek a federal forum only on appeal--surely, the very first response such a Justice would have given to Justice Stevens's concern would have been that Congress could easily fix the problem by granting the state cours jurisdiction over claims against the states under those statutes (particularly if the Justice regarded state judges as equally willing and able as federal judges to enforce federal law). The majority's failure even to mention that possibility as a reason Justice Stevens's concerns were "exaggerated" shows, at the very least, that the

181. See id.

182. See infra Part I.A.

183. This judgment is implicit in Congress's decision to give federal courts exclusive junsdiction. 
Justices in the majority have not internalized the forum-allocation interpretation of the Eleventh Amendment. ${ }^{184}$

\section{B. Pre-Seminole Tribe Support for the Immunity-from-Liability Interpretation}

"[F]ootnotes are a dangerous place to seek authoritative statements of law, particularly in a field as complex as [the Eleventh Amendment]." 185 If the subtle hints in Seminole Tribe were the only support for the immunity-fromliability interpretation, I would be the first to urge caution. Yet a fresh look at the pre-Seminole Tribe cases with the "immunity-from-liability versus forumallocation" question in mind shows that this is not just a conflict between clear Supreme Court holdings, some unanimous, supporting the forum-allocation interpretation and a few ambiguous footnotes supporting the immunity-fromliability interpretation. The immunity-from-liability interpretation, indeed, finds significant support in authority dating back to Chisholm.

\section{The Framers' Intent}

To a remarkable degree, recent Eleventh Amendment scholarship has sought to ascertain the intent of the Framers of the Amendment, and of Article III as originally adopted. Diversity theorists in particular have sought to make the case that the Court in Hans got its history wrong. The doctrinal payoff for their historical scholarship has been small, and not just if measured by its success in the Supreme Court. In response to scholarly challenges to the theory, the most persistent of the diversity theorists who stress Framers' intent, William Fletcher, ${ }^{186}$ has clarified the scope of his historical claims, and they appear to be quite modest. Although he claims that the Eleventh Amendment was not intended to withdraw "arising under" jurisdiction over suits against the states, he concludes that it is not at all clear that the Framers of Article III intended to extend the federal judicial power to suits against the states based

184. Scholars writing after Seminole Tribe have discussed Eleventh Amendment immunity as if it related to more than just the jurisdiction of the lower federal courts. See, e.g., Suing the State Gets Tough, LEGAL TIMES, July 29, 1996, at 441 (statement of Michael Masinter, Professor of Law, Nova Southeastern Univ.) (interpreting Seminole Tribe as adopting immunity-from-liability interpretation of Eleventh Amendment). But see Monaghan, supra note 34, at 125 (rejecting such an interpretation).

185. Fletcher, Historical Interpretation, supra note 7, at 1097.

186. I call Fletcher the most persistent because, after defending the diversity interpretation at some length in Fletcher, Historical Interpretation, supra note 7, he has twice responded in print to the theory's critics. See Correspondence, supra note 7; Fletcher, Diversity Explanation, supra note 7. The other diversity scholar who stresses Framers' intent is Gibbons, supra note 7. Although Amar, supra note 7, and Jackson, supra note 1, make Framers' intent arguments, they give greater prominence to arguments based on constitutional structure and principle. Granted, these latter arguments are based in part on arguments about the general values and principles held by the Founders, but Fletcher and Gibbons place greater emphasis on the evidence (or lack of evidence) of what the Framers intended to accomplish when they adopted the Eleventh Amendment. 
on federal law in the first place. This was, Fletcher writes, an "unsettled, and very difficult, question[] that [was] left to be answered as the meaning of the Constitution unfolded." 187 Hans, of course, settled the question (at least for a time), but the answer the Court provided does not satisfy Professor Fletcher because: (1) the Court in Hans mistakenly relied on the Eleventh Amendment instead of Article III: and (2) the Court mistakenly believed that history provided an answer. The first objection seems purely terminological. Substantively, Fletcher is willing to concede that an interpretation of Article III's "arising under" clause that would protect states transsubstantively ${ }^{188}$ from suits brought by individuals is not in conflict with the intent of Article III's Framers, and he expressly agrees that the Framers of the Eleventh Amendment did not mean to deny states that protection. As far as terminology is concerned, I am willing to stipulate that the term "Eleventh Amendment immunity" is shorthand for the protection that any part of the Constitution gives the states from the federal government's power to impose and enforce judicial remedies against them. The second objection is not an objection to Hans's conclusion, but rather to the way the Court arrived at it. The objection implicates profound issues of constitutional interpretation, as does the decision about how to respond to Hans's error, if such it be, after having lived with it and relied on it in many ways for just shy of a century. ${ }^{189}$ In the end, the disagreement between diversity theorists and their critics is not so much about history as about the relative weight constitutional interpreters should give to other types of arguments, including arguments about stare decisis ${ }^{1 \% 0}$ and about constitutional structure and principle. ${ }^{191}$

I do not propose to address those questions here. I instead make a modest claim about the Framers' intent: While there is conflicting evidence on whether the Framers of Article III and of the Eleventh Amendment intended to confer (or preserve) a right to sue states in federal courts for violating federal law, there appears to be no evidence that the Framers "intended" to establish the

187. Correspondence, supra note 7 , at 137

188. By this I mean without regard to the paricular provision of federal law sought to be enforted Fletcher's willingness to entertain the possibility that Arucle III might give states such transsubstanuve protection appears at first to confict with what I had taken to be his position: that whether states can be subjected to damage liability to indivaduals should tum on an interpretutuon of the parucular proviston of the Constitution that Congress claims to be exercising when it purports to subject the states to such liability See Fletcher, Historical Interpresarion. supra note 7. 3t $1108-09$ But the posituons are actually not in conflict. He apparently concedes that history does not proclude an interpretation of Arucle IIl that would give states such transsubstantive protection, but he offers nonhustoncal arguments for trealing the questuon as a matter of interpreting particular constitutional provisions giving Congress legislatuve powers See id at $1118-27$.

189. On this question. see Jackson, supra note 1, at 7 : and Sherry, supra note 42

190. See Marshall, supra note 7, al 1375 ("The nunety-nune years of jurnsprudence bult upon Hans creates a presumption in favor of the current interpretation of state immunty Review of the histoncal evidence and arguments, in tum, establishes that the diversity theorists have not overeome the presumption.").

191. See generally Amar, supra note 7 (relying heavily on arguments based on structure and pnnciple . Jackson, supra note 1 (relying on arguments based on structure. pnnesple. and judicial doctrne) 
forum-allocation principle that some regard the Eleventh Amendment as embodying. Indeed, there is some evidence that the Framers did not intend that principle. More importantly, given what virtually all scholars appear to agree was one of the Framers' key concerns when they adopted the Eleventh Amendment, it is unreasonable to attribute to them the intent to establish the forum-allocation principle. Thus, while the historical evidence may well be indeterminate as to whether the Eleventh Amendment was or was not meant to apply to claims under federal law, it cuts decidedly against the claim that the states are required to entertain federal damage actions against themselves in their own courts, subject to appellate review in the federal courts.

The critics of the diversity theory have made a convincing case that in adopting the Eleventh Amendment, "the framers clearly were motivated by a concern for the protection of state treasuries." 192 Fletcher agrees that the "adopters" of the Amendment "wanted to protect state treasuries," 193 and other "diversity theorists do not deny" this. ${ }^{194}$ As Fletcher describes it, the point of contention is this: While the diversity theory's critics maintain that the Framers meant to protect state treasuries from actions under federal law as well as state law, its defenders maintain that the desire to protect state treasuries

did not necessarily prevail over all others. It prevailed when state treasuries were at risk from suits, like Chisholm, based on non-federal law brought under the state-citizen diversity clause, for there was little countervailing federal interest. But when violations of federal law were at issue, the relative strength of the claim of the state treasuries was diminished. ${ }^{195}$

Whether the Amendment in the end left open the possibility of suing the states on federal claims depends, Fletcher says, on whether Article III allowed it in the first place, and that question, he concludes, was "both unresolved and very

192. Marshall, supra note 7 , at 1383.

193. See Correspondence, supra note 7, at 135-36, where Fletcher expresses agreement on this point with Calvin Massey, a critic of the diversity theory.

194. Marshall, supra note 7, at 1386; see also Cohens v. Virginia, 19 U.S. (6 Wheat.) 264, 406-07 (1821); RAOUL BERGER, CONGRESS v. THE SUPREME COURT 327 (1969); Amar, supra note 7, at 1474 n.202 (arguing that Framers of Eleventh Amendment were concerned with protecting states from debt actions); Alan D. Cullison, Interpretation of the Eleventh Amendment: A Case of the White Knight's Green Whiskers, 5 Hous. L. REV. I, 7 (1967); Herbert Hovenkamp, Judicial Restraint and Constitutional Federalism: The Supreme Court's Lopez and Seminole Tribe Decisions, 96 Colum. L. REv. 2213, 2240 (1996) (arguing that Eleventh Amendment is "concerned with private actions compelling states to pay their war debts" and that focus of debate was between those who wanted to bar federal as well as nonfederal actions against states and those who wanted to bar only nonfederal actions); Jackson, supra note 1, at 23; Nowak, supra note 58, at 1437-39.

195. Correspondence, supra note 7, at 136; see also Hovenkamp, supra note 194, at 2240 (arguing importance of federal-jaw claims against states under Treaty of Paris in historical debate over scope of Eleventh Amendment). 
difficult." 196 Taking the view more congenial to the diversity theory, it appears that for some Framers, the desire to protect state treasuries prevailed over the "countervailing federal interests" and for others it did not. As the Amendment did not reflect a meeting of the minds on this issue, Fletcher maintains, its adoption cannot be said to have resolved the dispute.

Perhaps not, but on one point we can attribute an agreement to the Framers: An arrangement under which the states courts would have been required to entertain suits seeking damages against states on the basis of federal law, subject to Supreme Court review, would not have satisfied anyone. The "countervailing federal interests" would have been sacrificed by such an arrangement, as enforcement of federal law would have been delayed. The states' interest in protecting their treasuries would not have been protected either if the states remained liable in damages under federal law and the Supreme Court remained available to enforce that obligation if the state courts did not. ${ }^{197}$ Even if the arrangement would have enabled the states to postpone the day of reckoning, the Supreme Court would presumably have had the power to award the federal rightholder interest to compensate for the delay. In any event, surely the Amendment was not designed to protect state treasuries by rewarding states' recalcitrance in complying with their federal obligations. In short, the forum-allocation interpretation is incompatible with any desire to protect state treasuries. ${ }^{198}$

That the Framers were not of the view that the states were required to entertain federal damage actions against themselves in their own courts is affirmatively suggested by the history of the Amendment's approval in the House. Among the versions of the Amendment that were rejected by the House was one that would have accomplished just that. This version would have limited the Amendment's application to suits against states "'where such State shall have previously made provision in their own courts, whereby such suit may be prosecuted to effect." 1999 This proposal was defeated overwhelmingly (77 votes to 8 ), and immediately thereafter the current version passed 81 to 9.200 The most reasonable interpretation of this history is that whatever

196. Correspondence, supra note 7, at 136.

197. The Supreme Courts jurisdiction under section 25 of the Judiciary Act to review state coun decisions denying federal rights was mandatory. See HART \& WECHSLER, supra note 100, al $492-93$.

198. At least some diversity theorists have expressed skeptucism about the forum-allocation interpretation. See Amar, supra note 7, at 1477-78 nn.209 \& 211: Fleıcher. Histoncal Interpresanon. supra note 7, at 1093-99; see also ORTH, supra note 42, at 11, 139. 151 (expressing skepticism). Tnbe, supra note 58, at 692 (same). But cf. Gibbons, supra note 7. at 1937 n.256 (considerng forum-allocalion view "reasonable"). Less surprisingly, the few defenders of Hans rejoct the forum-allocation view. See. e.g . DAVID CURRIE, FEDERAL COURTS 573 (1975) ("[D]o you really believe the storm over Chisholm v. Georgia was over so trivial a matter as the choice of forum?").

199. JACOBS, supra note 42, at 66-67 (quoting 4 ANNALS OF CONG. $476-77$ (Mar. $\$$. 1794)).

200. See id. 
protection the Framers wanted to give the states was assumed to apply in state court as well as federal court. ${ }^{201}$

\section{The Continuing Doctrinal Connection Between the Eleventh Amendment and the Protection of State Treasuries}

The Justices in the majority in Seminole Tribe appeared distinctly, if uncharacteristically, uninterested in historical arguments. ${ }^{202} \mathrm{I}$ am certainly not arguing that evidence of the Framers' intent should prevail in this area over such other indicia of constitutional meaning as evolved judicial doctrine. But, where the Framers' intent on a particular subject has been and continues to be relied on by the Court in resolving constitutional questions, the case for taking that intent seriously in resolving related questions is, in my view, strong. In this Section, I show that the Court continues to resolve questions in the Eleventh Amendment area by invoking the idea that the Amendment's purpose is to protect state treasuries-a purpose that, as noted already, is simply incompatible with the forum-allocation interpretation of the Eleventh Amendment. This case law not only strengthens the argument for taking seriously the evidence that the Framers indeed had that purpose, it also supplies independently relevant doctrinal support for the immunity-fromliability interpretation of the Eleventh Amendment. ${ }^{203}$

201. My review of the secondary literature has uncovered no persuasive support for the idea that the Framers intended to establish a forum-allocation principle. Clyde Jacobs has noted that Spencer Roane, Marshall's political enemy on the Virginia Court of Appeals, see HART \& WECHSLER, supra note 100, at 496, insisted in response to the decision in Cohens $v$. Virginia that the Eleventh Amendment was not adopted, as Marshall had suggested, "'on the sordid ground of unwillingness in the States to pay debts," but instead reflected an objection to requiring states to defend suits in the federal courts. See CHARLES G. HAINES, 1 THE ROLE OF THE SUPREME COURT IN AMERICAN GOVERNMENT AND POLITICS, 1789-1835, at 441 (1960) (quoting Roane) cited in JACOBS, supra note 42, at 91-92. Roane's point, however, was decidedly not that state courts would entertain suits against the states at the behest of individuals, as he mentions in the same very discussion (approvingly) the resolution passed by the Virginia legislature in response to Chisholm to the effect that "a State cannot, under the Constitution of the United States, be made a defendant at the suit of any individual." HalNES, supra, at 441 . He certainiy would not have agreed that the Supreme Court could review a state court decision dismissing a suit against a state based on federal law. That position conflicts with the entire thrust of his comments in response to Cohens, as well as with his opinion for the Virginia Court of Appeals in Hunter $v$. Fairfax's Devisee, 15 Va. (1 Munf.) 218, 223-32 (1810), rev'd sub nom. Martin v. Hunter's Lessee, 14 U.S. (1 Wheat.) 304 (1816), which denied the power of the Supreme Court to review the decisions on federal questions rendered by state courts even in suits involving only private parties.

202. The majority denigrated Justice Souter's dissent, which relied extensively on historical scholarship conceming the intent of the Founders, as "a theory cobbled together from law review articles and its own version of historical events," and it described the dissent's "extralegal" explanation of the Hans decision as "a disservice to the Court's traditional method of adjudication." Seminole Tribe v. Florida, $116 \mathrm{~S}$. $\mathrm{Cl}$. $1114,1129-30$ (1996).

203. It is arguable that reasons of doctrinal coherence would justify a court in continuing to rely on a supposed "intent" of the Framers if it has done so in the past, even if it could be shown that the Framers did not in fact have any such intent. If so, then the doctrine I shall discuss in the rest of this Part may supply sufficient reasons for rejecting the forum-allocation interpretation of the Eleventh Amendment even if the evidence of Framers' intent I just discussed did not exist. Moreover, where, as here, there is doctrinal 


\section{a. The Edelman Line of Cases and the Prospective/Retrospective Distinction}

As noted, the Court has long drawn a distinction for Eleventh Amendment purposes between suits against the states and suits against state officials. The Eleventh Amendment does not bar suits against state officials who are alleged to be violating federal law, on the theory that because the states lack the power to authorize their officials to violate federal law, an official who does so is not, in contemplation of law, acting in the name of the state. Notwithstanding the notion that the official is not acting in the name of the state for Eleventh Amendment purposes, the Court has no trouble in this context concluding that the official's action is state action sufficient to make the Constitution's substantive prohibition applicable. The Ex parte Young "authority-stripping" rationale for escaping the Eleventh Amendment bar is now understood to rest on a "fiction," 204 a fiction the Court has considered necessary to "give[] life to the Supremacy Clause."205 Courts and scholars now recognize that the defendant in an Ex parte Young action is for all practical purposes the state

support for conflicting interpretations, evidence that the Framers in fact did have such an intent may tult the scales in favor of the one consistent with that intent.

On the other hand, I am willing to discount evidence of Framers' intent that is based on conceptrons that are no longer widely shared. On this score, I should address a possible objection to my relance on the Framers' apparent assumption that state courts were not required to entertain in their own courts surts brought by individuals against them based on federal law. It may well be that this assumption wias based on their broader assumption that state courts were under no obligation to entertan federal claums of any sort. See Michael G. Collins, Article III Cases, State Court Duties, and the Mtadisontan Compromtse. 1995 WiS. L. REv. 39 (defending latter position). As applied to federal suits against individuals, this broader assumption conflicts with a great deal of entrenched case law that recognizes an obligatuon of states under the Supremacy Clause to entertain federal law suits in their own courts, at least if those courts have jurisdiction over analogous suits based on state law. See generally id. at 166-70 (discussing Testo v. Kont. 330 U.S. 386 (1947), and retated cases). I regard the latter line of cases as well-seilled and accept the principle they established as part of our constitutional landscape. Indeed. I substantally agree with those who have argued that the state couns would be under a constitutional obligation to enicrain (at least) suits seeking injunctive relief from constitutional violations by state or federal offictals, (at least) if Congress denied the federal courts jurisdiction over such suits. See, e.g. HART \& WECHSLER. supra note 100. at 373-79, 469. (It appears that Collins does not disagree with this, although he would prefer to say that such an action is a "state-law" action. See Collins, supra, at 164-66 n.359 (discussung General Onl Co. v. Cratn, 209 U.S. 211 (1908)).) I do not regard the evidence that the Founders held a contrary assumption to be pan of our usable past. It is nevertheless legitimate to rely on the Founders" narrover assumption that states were not required to entertain federal law suits for damages against themselves in their oun couns. even if their narrower assumption was based on their broader assumption. The consequence of the broader assumption (as applied to suits involving only individuals) was simply to require Congress to create lower federal courts and endow them with jurisdiction over such suits. somethung that Congress has done and is unlikely to undo, particularly with respect to suits to enforce federal statutes. In Iight of the Eleventh Amendment, the consequence of the narrower assumption was to deny Congress the pow er to create any judicially enforceable liability against the states. The Founders' application of the broader pnnesple to the specific context of suits against the states has a special relevance to what they understood would be accomplished by the Eleventh Amendment. Moreover, the Founders' views on this narrower issue conunue to be invoked by the Court today, whereas their views on the broader question are nghtly considered par of a "jurisdictional Stone Age." Collins, supra, at 170.

204. Pennhurst State Sch. \& Hosp. v. Halderman, 465 U.S. 89.114 n.25 (1984).

205. Green v. Mansour, 474 U.S. 64. 68 (1985). 
itself, ${ }^{206}$ but the Eleventh Amendment does not bar such suits even though they often will result in a judicial order requiring the significant expenditure of state resources. ${ }^{207}$

In Edelman v. Jordan, ${ }^{208}$ the Court drew a distinction between suits seeking prospective relief from ongoing violations of federal law and suits seeking retrospective relief from past violations of federal law. The Eleventh Amendment does not apply to suits seeking prospective relief even though the costs will be borne by the state, but it does bar suits seeking retrospective relief if the damages are sought from the state. ${ }^{209}$ The Court has not had an easy time distinguishing prospective from retrospective relief. For present purposes, we need not examine where the line falls or how convincing or stable the Court's jurisprudence in this area has been. Edelman and succeeding cases are important to us because of what they show about how the Court conceives of Eleventh Amendment immunity.

The Court in Edelman did not explain the policies advanced by interpreting the Eleventh Amendment to permit suits seeking prospective relief, but not suits seeking retrospective relief. But a clue to the Court's thinking can be found in its response to Justice Douglas's claim that the effect on the state treasury is the same in both circumstances. The majority stated:

This argument neglects the fact that where the State has a definable allocation to be used in the payment of public aid benefits ... the subsequent ordering by a federal court of retroactive payments to correct delays in such processing will invariably mean there is less money available for payments for the continuing obligations of the public aid system. ${ }^{210}$

Of course, an order of retroactive benefits by a state court would have precisely the same effect. The majority's response to Douglas was accordingly no response at all if it conceived of the Eleventh Amendment as merely a forum-allocation principle, reflecting, as Justice Powell indicated in Atascadero, a confidence that state courts would give effect to federal law faithfully, and subject in any event to review by the Supreme Court. The majority's response makes sense only if it viewed the Amendment as

206. Although, as the Court in Seminole Tribe reminded us, the Eleventh Amendment still immunizes states from being sued by private parties by name, even for prospective relief. See Seminole Tribe, $116 \mathrm{~S}$. Ct. at 1122; see also HART \& WECHSLER, supra note 100, at 1073 .

207. See, e.g., Milliken v. Bradley, 433 U.S. 267 (1977).

208. 415 U.S. 651 (1974).

209. The Eleventh Amendment does not bar a suit seeking retrospective relief from the officer's own resources. See HART \& WECHSLER, supra note 100, at 1076. In this context, however, the officer will be protected by an "official immunity" that protects her from liability if her conduct did not violate "clearly established" federal law. See Harlow v. Fitzgerald, 457 U.S. 800, 818 (1982).

210. 415 U.S. at 666 n.11. 
protecting state coffers, something that only the immunity-from-liability interpretation would do.

Its subsequent decision in Quern $v$. Jordan ${ }^{211}$ confirmed that this is how the Court viewed the Amendment. After the Edelman case was remanded, the lower federal courts ordered the state official to send members of the plaintiff class a "mere explanatory notice... advising them that there is a state administrative procedure available if they desire to have the state determine whether or not they may be eligible for past benefits."'12 The Cour upheld this notice requirement as ancillary to the prospective injunctive relief the Court had upheld in Edelman. In explaining its decision, the Court stressed that under the notice, "whether or not the class member will receive retroactive benefits rests entirely with the State, its agencies, courts, and legislature, not with the federal court." ${ }^{213}$ In Green v. Mansour, ${ }^{214}$ the Cour explained Quern as standing for the notion that "state agencies rather than federal courts would be the final arbiters of whether retroactive payments would be ordered."215 These statements are inconsistent with the forum-allocation interpretation of the Eleventh Amendment. As discussed in Part I, if the Amendment relates only to the original jurisdiction of the federal courts, it tells us nothing about whether the states are under a federal obligation to provide retroactive payments to individuals. If a statute does require such payments, then the Supremacy Clause would require the state courts to award such relief, and if the state courts violate that obligation, the Supreme Court would have jurisdiction to reverse their judgments. Thus the availability of retrospective relief would not depend on action by the state "legislature," and state agencies would not be the "final arbiters of whether retroactive payments would be ordered." The Court's statements would be true only if there were no federal obligation to afford individuals monetary relief (or no Supreme Court power to enforce that obligation). However, if that is what the Cour held in these Eleventh Amendment decisions, it understood the Amendment to bear on liability, not just the original jurisdiction of the federal courts. ${ }^{216}$

211. 440 U.S. 332 (1979).

212. Id. at 336 (quoting Jordan v. Trainor. 563 F.2d 873.875 (7th Cir. 1977) (en banc), aff'd. tho U.S. 332).

213. Id. at 348.

214. 474 U.S. 64 (1985).

215. Id. at 71 .

216. Vicki Jackson has pointed out that the statute involved in Green expressly required the states. as a condition of receiving federal funds, to compensate individuals for benefils that had been wrongfully withheld, and that although the statute apparently did not require states to grant judicial review of dectsions not to compensate, the state of Michigan (the relevant state in Green) had made judicial review avalable. Thus, the Court's statement that the state courts and state legisiatures would be the "final arbiters" of whether individuals would receive payment would apparently have been wrong even if ue assumed the correctness of the immunity-from-liability interpretation. The state undertook: to provide retrospoctuve relief in exchange for federal funds, thus incurring a federal obligation, and the state's voluntary dectsion to grant judicial review would appear to satisfy Seminole Tribe's "consent" condition for Supreme Coun review of a Michigan court's erroneous decision to deny such relief. The Court in Green appears to have overlooked these propositions. But this does not detract from the conclusions reached above-that the Coun's analysis 
That the Court so viewed the Amendment is suggested further by the Court's explanation in Green and in Papasan v. Allain ${ }^{217}$ of the rationale for distinguishing between prospective and retrospective relief. The Court wrote in Green:

Both prospective and retrospective relief implicate Eleventh Amendment concerns, but the availability of prospective relief of the sort awarded in Ex parte Young gives life to the Supremacy Clause. Remedies designed to end a continuing violation of federal law are necessary to vindicate the federal interest in assuring the supremacy of that law. But compensatory or deterrence interests are insufficient to overcome the dictates of the Eleventh Amendment. ${ }^{218}$

The Court here speaks of Eleventh Amendment immunity as if it determined the type of relief available for violations of federal law, not as merely specifying the initial forum in which such relief may be obtained. If the Amendment had been perceived as merely allocating the initial duty to enforce federal norms in certain circumstances to a nonfederal forum considered equally effective, the Court's rationale would not make much sense, for the interest in deterring and compensating in those instances would not be sacrificed in the state forum, nor would the interest in stopping ongoing violations of federal law be compromised by relegating that form of relief to state courts. The Court seems to be saying in these cases that prospective relief is all that is needed to give federal norms efficacy; deterrence and compensation are not necessary and are accordingly unavailable. ${ }^{219}$

in this case is in substantial tension with the forum-allocation interpretation. Indeed, Professor Jackson makes that point herself. See Jackson, supra note 1, at 71-72 (referring to Green's "inconsistency with [the idea that the] Supreme Court [has the power to review] state cases involving federal questions").

217. 478 U.S. 265 (1986).

218. 474 U.S. at 68 (citations omitted). In Papasan, the Cour quoted the last two of these sentences and added that the Young doctrine applies to cases "in which the relief against the state official directly ends the violation of federal law as opposed to cases in which that relief is intended indirectly to encourage compliance with federal law through deterrence or directly to meet third-party interests such as compensation." 478 U.S. at 278.

219. There is perhaps an explanation of the Court's differing treatment of prospective and retrospective relief that would be consistent with the forum-allocation interpretation of the Eleventh Amendment, but this explanation rests on an assumption that the defenders of Hans have been unwilling to make (at least publicly): that state courts can be expected to be less vigorous than federal courts in enforcing federal norms. If we make this assumption, then the different treatment of prospective relief and retrospective relief may be explained as being based on the conviction that the need to stop ongoing violations of federal law is more pressing than the need to compensate victims of past violations or the need to deter future violations by punishing past violations. Litigants seeking the less pressing forms of relief may be relegated to the more burdensome process of suing in state courts with a possible appeal to the Supreme Court. Where the violation of federal law is already in the past, respect for the dignity of the states outweighs the need for quick relief. The premise of this argument may not be true; for example, someone who illegally has been denied public benefits can be expected to have an exceedingly pressing need for those benefits. Indeed, the need for wrongly witheld past due benefits is likely to be more pressing than the need for not yet due benefits (the payment of which federal courts have the power to order under Edelman and Hutto). If one accepts this premise, the distinction may make some sense. On this theory, Congress validly may determine that deterrence and compensation are important enough to warrant subjecting states to liability. 


\section{b. Hess and the Question of What Counts as the State}

That at least one of the purposes of the Eleventh Amendment is to protect state coffers plays a prominent role as well in the case law concerning which entities count as the "state" for purposes of the Eleventh Amendment. As noted, the general rule is that the Amendment protects statewide agencies but not local government agencies. ${ }^{220}$ Occasionally, the courts are confronted with an agency that does not clearly fall into either category. The Court confronted such a question most recently in Hess $v$. Port Authority TransHudson Corp. ${ }^{221}$ which involved an entity created by interstate compact. In reaching its decision that the Eleventh Amendment did not protect the entity from a suit in federal court under FELA, the Court stressed that "the vulnerability of the State's purse [is] the most salient factor in Eleventh Amendment determinations" goals of the immunity of the Eleventh Amendment is to shield states' treasuries." "'223

As noted above, if the Eleventh Amendment merely protects the states from the jurisdiction of the lower federal courts, it does not shield the states' treasuries. ${ }^{224}$ Justice Powell in Atascadero was confident that the state courts would comply with their duty to enforce federal law, ${ }^{225}$ but the state treasury would not be a beneficiary of a forum-allocation interpretation of the Eleventh

but the Eleventh Amendment reflects a constitutional judgment that such remedies are not so impornant that they require immediate access to the lower federal courts. The Supreme Cour has not articulated this rationale for the Amendment, however. Indeed, its current approach appears to be based on the assumption that state courts faithfully will enforce the states' federal liabilities. See infra text accompanying notes $438-40$.

The suggestion in these cases that retrospective reltef is unnecessary to secure the efficacy of federal law is, to be sure, in tension with the nule-of-law ideal. See supra note 16 and accompanying text. As discussed in Par VI, the availability of retrospective relief aganst state offictals alleviales thus difficulty substantially. In addition to the other mistakes the Court made in Green. see supro note 216. We may add its overlooking the fact that Edelman left open the possibility of obtanning damages payable by stalc officials personally.

220. See supra note 100

221. 115 S. Ct. 394 (1994).

222. Id. at 404 .

223. Id. at 405 (quoting Jacintoport Corp. v. Greater Baton Rouge Pont Comm'n. 762 F.2d 435 . 440 (5th Cir. 1985)); see also id. ("."[T]he state treasury factor is the most important factor to be considered . . and, in practice, . . . [is] generally accorded . . . dispositive weight."') (quoting Bnef for the States of Neu Jersey, New York, et al. as Amici Curiae at 18-19. Hess v. Port Auth. Trans-Hudson Corp . $115 \mathrm{~S}$. Ct. 39: (1994) (No. 93-1197)). That protecting state treasuries is one of the purposes of the Eleventh Amendment appears to have been the view of all of the Justices in Hess. The four dissenung Jusuces would have regarded an impact on the state treasury to be a sufficient condition for applyıng the Eleventh Amendment, but criticized the majority for apparently making it a necessary condition. See id. al $\$ 10$ (O' Connor. J. dissenting). Whether a threat to the state treasury is indeed a necessany condiuon will be addressed by the Supreme Court in reviewing Doe $v$. Lawrence Livermore Nononal Laboralon, which relied heavily in concluding that the agency was not entitled to Eleventh Amendment immunity on the United Sintes government's agreement to reimburse a state agency for any damages assessed agaunst tt. See 65 F.3d 771 (9th Cir. 1995), cert. granted sub nom. Regents of Univ. of Cal. v. Doc. 116 S. C. 2522 (1996).

224. See supra text accompanying notes $86-89$.

225. See supra text accompanying note 143 . 
Amendment even if we made more realistic assumptions about state court judges, for under the forum-allocation interpretation, the Court would retain the power to monitor state compliance with federal obligations. Requiring litigants to pursue their claims against the states through several levels of (by hypothesis) hostile state courts before reaching a federal tribunal might result in some marginal gain to state treasuries if litigants decided that the cost of litigation was not worth the potential gain, ${ }^{226}$ but surely the Court did not mean in Hess that the point of the Eleventh Amendment was to enable the states to save money by engaging in scorched-earth tactics. The Court's endorsement in Hess of the idea that the Eleventh Amendment was designed to protect state treasuries is, in short, irreconcilable with the forum-allocation interpretation.

\section{Additional Support in the Case Law for the Immunity-from-Liability Interpretation}

That one of the purposes of the Eleventh Amendment is to protect state treasuries is a thread stretching from the Founding to the Supreme Court's $1994 \mathrm{Term}$, and, for the reasons discussed above, this thread is inconsistent with the forum-allocation interpretation. But there is more support in the case law for the immunity-from-liability view. I shall not attempt to quote all of the statements in Supreme Court opinions that support the immunity-from-liability view by describing the immunity conferred by the Amendment as an immunity from unconsented "suits" without going on to specify that the protection applies only in state courts. ${ }^{227}$ Nor shall I refer to other statements in Supreme Court opinions supporting the immunity-from-liability view if those statements were not central to the Court's analysis of the issues before it. ${ }^{228}$ I shall limit myself to what I regard as the major cases, or lines of cases, that tend to support the immunity-from-liability interpretation of the Eleventh Amendment.

226. See Jackson, supra note 1 , at 64 n.262.

227. See, e.g., Monaco v. Mississippi, 292 U.S. 313, 322-23 (1934) ("There is also the postulate that States of the Union, still possessing auributes of sovereignty, shall be immune from suits, without their consent, save where there has been 'a surrender of this immunity in the plan of the convention."') (quoting The Federalist No. 81, at 487 (Alexander Hamilton) (Clinton Rossiter ed., 1961)) (emphasis added); Ex parte New York, 256 U.S. 490, 497 (1921) ("That a state may not be sued without its consent is a fundamental rule of jurisprudence ....").

228. For example, the Court stated in Kiefer \& Kiefer v. Reconstruction Finance Corp., 306 U.S. 381 (1939), a case involving the immunity of a federally chartered corporation, that "[a]s to the States, legal irresponsibility was written into the Eleventh Amendment," id. at 388. I am not counting as support for the immunity-from-liability interpretation statements in dissenting opinions by Justices who adhere to the diversity interpretation and/or regard the immunity as subject to abrogation by Congress under any of its powers. For an example of one such statement, see supra text accompanying note 141. Cf. Hess v. Port Auth. Trans-Hudson Corp., 115 S. Ct. 394 (1994); infra text accompanying notes 255-58 (discussing Hess majority opinion in which Justices who regard immunity as subject to plenary congressional abrogation make statements that support immunity-from-liability interpretation of Eleventh Amendment). 
a. Hans

If Seminole Tribe resurrects the Hans interpretation of the Eleventh Amendment, then it makes sense to ask just how the Court in Hans conceived of the immunity it conferred. Many scholars have pointed out the flaws in the Hans Court's analysis. My purpose is not to defend the decision but to understand it. Examination of the Hans decision shows that the Court clearly did not embrace the forum-allocation interpretation of the Eleventh Amendment. Such an examination of the Hans opinion also supplies additional pre-Hans support for the immunity-from-liability view.

The Court in Hans concluded that the Eleventh Amendment applied to cases brought by individuals against their own state, even though the Amendment does not by its terms apply to such cases, because the Amendment's Framers intended to constitutionalize the common law sovereign immunity of the states, which the Chisholm Cour had mistakenly interpreted Article III to have withdrawn. The common law immunity constitutionalized by the Amendment appears to have been an immunity from liability. The Court in Hans, for example, relied on statements of Alexander Hamilton in The Federalist No. 81 to the effect that the states retained their sovereign immunity. ${ }^{229}$ What Hamilton said was that "[ $\left.t\right]$ he contracts between a nation and individuals are only binding on the conscience of the sovereign, and have no pretensions to a compulsive force. They confer no right of action independent of the sovereign will." 230 The Coun similarly relied on a

229. See Hans, 134 U.S. at 12-14.

230. The Federalist No. 81, at 488 (Alexander Hamilion) (Clinion Rossiter ed., 1961) (emphasis added); see also Hans, 134 U.S. at 16 (relying on statement of Dantel Webster that "[t]he secunty for stale loans is the plighted faith of the State as a political community. It rests on ... the good faith of the govemment making the loan, and its ability to fulfill its engagements."). It is true that Hamilton and Webster referred only to liability under the common law', so they arguably would not have extended this reasoning to federal norms. Indeed, there is a strong argument to be made that the analysis of Hamilion and Webster should have led the Coun in Hans to adopt the diversity interpretation. The staring point of Hamilton's analysis was the idea that there can be no right of action, no judicial remedy. agannst the states as sovereigns. He deduced from that premise the conclusion that the federal courts lacked junsdictuon over suits against the states, but he deduced from the same premise the conclusion that the states were under no primary legal obligation to comply with their contracts in the first place. Hamilton's reasoning reflects what I have elsewhere called a sanctionist view of law, under which a legal duty is sand to exist only if its violation subjects the violator to a judicially enforceable sanction. This is a vew of law to which I am sympathetic, and, indeed, it is a view of law that has resonated powerfully in the Amencan legal culture since its inception. See generally Vázquez, supra note 80 . What is important for present purposes is that. at first blush anyway, it seems to require a holding different from the one the Court amved at in Hans. If a duty that is not judicially enforceable is not a legal duty, then it would seern to follow from the fact that the Constitution itself imposes duties on the states and declares those duties to be the "law of the land" that the Eleventh Amendment cannot protect states from suits to enforee those dutues. If so, then perthaps the Hans Court could have cited Hamilton for the proposition that while the states cannot be sued in the federal courts under the common law, they can be sued in federal court to enforce the duues imposed on them by the supreme law of the land. Because the Court rejected that interpretation. It must have understood Hamilton's statements differently. In light of Hans. perhaps we should take hum to be making a point about contractual obligations that is not necessarily true about the other obligations of the statc. Because traditionally the exclusive way to enforce contracts judicially has been for one party to sue the other in 
statement by James Madison that "'[i]t is not in the power of individuals to call any State into court,",231 as well as on a statement by John Marshall that “"[i]t is not rational to suppose that the sovereign power should be dragged before a court." ${ }^{\text {"232 }}$ Neither statement is consistent with the idea that the states are required to entertain suits against themselves in their own courts. The Court also cited Justice Miller's discussion in Cunningham v. Macon \& Brunswick Railroad:

"It may be accepted as a point of departure unquestioned, that neither a State nor the United States can be sued as defendant in any court in this country without their consent, except in the limited class of cases in which a State may be made a party in the Supreme Court of the United States by virtue of the original jurisdiction conferred on this court by the Constitution.,"233

The Court relied further on Chief Justice Taney's statement for the Court in Beers $v$. Arkansas that " "[i]t is an established principle of jurisprudence in all civilized nations that the sovereign cannot be sued in its own courts, or in any other, without its consent and permission."'234 The Court described Justice Iredell's opinion in Chisholm, with approval, as "contend[ing] that it was not the intention [of the Founders] to create new and unheard of remedies, by subjecting sovereign States to actions at the suit of individuals."235

The immunity-from-liability interpretation is supported further by the Hans Court's alternative holding that the general federal question statute as it then existed did not confer jurisdiction over damage actions brought by individuals against states. The Court relied on the language in the statute conferring

court, Hamilton was perhaps justified in concluding that a contract that cannot be enforced in court by one party does not really impose legal obligations on the other party. The federal constitutional obligations of the states, however, can be enforced in court in ways other than through suits for damages by private individuals. See supra Section I.C; infra Part VI. Thus, denying individuals the right to obtain damages from the states for their violations of federal law does not leave those obligations entirely without a judicially enforceable sanction. If this is how the Court took Hamilton, then we are left with: (1) Hamilton's statement that individuals can possess no right of action for damages against the states; and (2) the Hans Court's holding that this lack of remedy extended to suits to enforce federal obligations. These propositions add up to the conclusion that individuals can possess no right of action for damages against the states under federal law.

231. 134 U.S. at 14 (quoting 3 The Debates IN the Several State Conventions on the ADOPTION OF THE FEDERAL CONSTITUTION AS RECOMMENDED BY THE GENERAL CONVENTION AT PHILADELPHIA IN 1787 TOGETHER WTTH THE JOURNAL OF THE FEDERAL CONVENTION, LUTHER MARTIN'S LETTER, YATES'S MINUTES, CONGRESSIONAL OPINIONS, VIRGINIA AND KENTUCKY RESOLUTIONS OF' 98-99 AND OTHER ILLUSTRATIONS OF THE CONSTITUTION 533 (reprint 1987) (Jonathan Elliot ed., New York, Burt Franklin 1888) [hereinafter DEBATES] (statement of James Madison)).

232. 134 U.S. at 14 (quoting 3 DEBATES, supra note 231, at 555 (statement of John Marshall)).

233. Id. at 17 (quoting Cunningham v. Macon \& Brunswick R.R., 109 U.S. 446, 451 (1883)) (emphasis added).

234. Jd. (quoting Beers v. Arkansas, 61 U.S. (20 How.) 527, 529 (1857)) (emphasis added).

235. Id. at 12 (emphasis added). The Court in Hans also said that suits against the states "are not subjects of judicial cognizance," $i d$. at 15 , again without limiting itself to the federal judiciary. 
jurisdiction on the federal courts "concurrent with the courts of the several states." 236 The Court said:

Does not this qualification show that Congress, in legislating to carry the Constitution into effect, did not intend to invest its cours with any new and strange jurisdictions? The state courts have no power to entertain suits by individuals against a State without its consent. Then how does the Circuit Court, having only concurrent jurisdiction, acquire any such power? $?^{237}$

The Court thus assumed that states were free to close their courts to claims against them based on federal law. ${ }^{238}$ Like the other statements quoted above, this one conflicts with the forum-allocation interpretation of the Eleventh Amendment, which posits that though the Amendment protects the states from the jurisdiction of the lower federal courts, it does not protect them from being subjected to liability to individuals, and if federal law imposes such a liability, they must entertain suits against themselves in their own courts, subject to Supreme Court review. ${ }^{239}$

\section{b. Poindexter}

Another Supreme Court decision that appears to conflict with the forumallocation interpretation of the Eleventh Amendment is Poindexter v. Greenhow. ${ }^{240}$ It is perhaps surprising to find Poindexter among the cases that support a broad interpretation of the Eleventh Amendment, for that case is best known for its strong affirmation of the importance of federal remedies and federal jurisdiction for the enforcement of federal constitutional rights, as well

236. Id. at 18 .

237. Id.

238. A similar argument appears in Justice Iredell's dissent in Chisholm. See Chisholm v. Georgia. 2 U.S. (2 Dall.) 419, 436-40 (1793) (Iredell. J.. dissenting). There is perhaps another available reading of this part of Hans. The Court here held that the general federal question statule did not confer junsdiction over suits against states. Because this was an alternative holding. perhaps we should understand this pan of the Court's opinion as proceeding from the assumption that Congress does have the power to subject the states to suit in federal court. Thus, it might be argued that the Court contemplated that states would be able to close their doors to federal claims against them only because (it was assuming) Congress would have the power to open the federal doors to such claims if it should find it desirable to do so. The Court's discussion does not seem susceptible to such a reading, however. The Coun had just held that the Eleventh Amendment protected states from being subjected to suit in federal cour. It is true that the statutory interpretation issue would arise only if that holding were rejocted (that is the nature of altemative holdings). but it is nevertheless noteworthy that the Coun nowhere suggested that the states' power to close theit doors to federal claims against them would exist only if its aliematuve holding were rejected.

239. The Court itself has read Hans as recognizing an immunity of states from sutt in state as well as federal court. See Palmer v. Ohio, 248 U.S. 32, 34 (1918) ("The right of individuals to sue a Sizle, in either a federal or a state court, cannot be derived from the Consutution or laws of the United States it can come only from the consent of the State.") (citing, inter alia. Hans v. Loursiana. 13.1 U.S. I (1890))

240. 114 U.S. 270 (1885). 
as for its articulation of the reason the Eleventh Amendment did not stand in the way of the remedy being sought in the case. The remedy being sought in that case, however, was a remedy against a state official, not a remedy against the state. The official forcefully argued that the Eleventh Amendment barred the suit anyway, as he was being sued for action he took in his official capacity, but the Court rejected the argument for the now familiar reason, today most closely associated with the later decision in Ex parte Young, ${ }^{241}$ that a state official who violates federal law cannot be acting within the scope of his authority, for federal law, being the supreme law of the land, limits his authority. Because of the Supremacy Clause, the Court held in Poindexter, the state is without power to authorize his violation of federal law, and the official is accordingly subjected in his person to liability for the injuries he caused. ${ }^{242}$

What is significant for our purposes is that the Court's lengthy affirmation of this principle came in a case that was brought in the state courts. There are two possible reasons why the Court thought it necessary to discuss the Eleventh Amendment in this case, and both are inconsistent with the forumallocation interpretation. First, the Court may have believed that the Amendment applied in state court because it conferred an immunity from liability, not just from federal jurisdiction. Second, the Court may have believed that the Amendment, when it applies, limits the Court's appellate jurisdiction. I suggested above that these two reasons are actually one and the same, for a liability against the states that is not enforceable in the federal courts is, as a practical matter, no liability at all. That the Court in Poindexter engaged in an extended discussion of the Eleventh Amendment in a case brought in the state courts without bothering to say why the Amendment was relevant suggests that the Court, too, regarded the reasons as identical.

\section{c. Abrogation Cases}

In Section II.B, I discussed some abrogation cases that support the forumallocation interpretation of the Amendment, cases recognizing that failure to find an abrogation of Eleventh Amendment immunity does not mean that the states are free of monetary liability to individuals. Other abrogation cases, however, support the immunity-from-liability interpretation.

In Atascadero, Justice Powell's majority opinion insisted that a state statute generally consenting to suit does not amount to a waiver of Eleventh Amendment immunity. A waiver will be found only where the state's intent to submit to lawsuits in federal court is so clear that no other inference may be drawn. ${ }^{243}$ The Court adopted the same clear statement rule for purposes

241. 209 U.S. 123 (1908).

242. See Poindexter, 114 U.S. at 285-89.

243. See Atascadero State Hosp. v. Scanlon, 473 U.S. 234, $239-40$ (1985). 
of finding a congressional abrogation of Eleventh Amendment immunity. ${ }^{2+4}$ Yet in recent cases, the Court has been willing to find a congressional abrogation of Eleventh Amendment immunity if the statute makes it clear that Congress intended to subject states to monetary liability to private individuals, even if the statute does not go on to make it clear that Congress intended that this liability be enforceable in federal court. Perhaps the most noteworthy of these cases is Union Gas. There, all of the Justices, in examining the abrogation issue, looked for evidence that Congress intended to hold states liable to private individuals, but none looked for evidence that Congress intended this liability to be enforceable in federal cour. The Justices who dissented on this issue did so because the majority, in their view, failed to produce sufficient textual evidence to rebut the possibility that Congress contemplated that the primary obligations imposed on the states by the statute be enforceable only at the behest of the federal government. ${ }^{245}$ Vicki Jackson has provided a convincing explanation of why the Justices were justified in focusing solely on the liability issue, notwithstanding Atascadero: The federal courts were given exclusive jurisdiction over the statute involved in Union Gas. ${ }^{246}$ It is at least curious that none of the opinions mentioned this point. This silence suggests that at least some of the Justices understood the Amendment to bear on the liability issue, not just the jurisdictional question.

Similar suggestions appear in other opinions. Those of Justice Scalia are perhaps the most revealing. In Union Gas, he explained his concurrence in Justice Brennan's abrogation holding as being based on Brennan's showing that the statute involved "clearly renders States liable for money damages in private suits." 247 He made no mention of federal courts. Scalia made clear in his brief concurring opinion in Dellmuth $v . M u t h^{248}$ that, in his view, an abrogation of Eleventh Amendment immunity should be found in "statutory text that clearly subjects States to suit for monetary damages."249 If this had been written by another Justice, one might think that he had merely overlooked the need for a clear statement of the state's amenability to suit in federal court. One does not expect such technicalities to be overlooked by Justice Scalia when they serve to insulate states from federal power. A likely explanation is that Justice Scalia views the states' immunity under the Eleventh Amendment as an immunity from liability, not just from federal court jurisdiction.

244. See id. at 240; see also id. at 253 n.5 (Brennan, J.. dissenting) ("The . . test that the Count applies to purported state wajvers of sovereign immunity is a mirror image of the test il applies to congressional abrogation of state sovereign immunity.").

245. See Pennsylvania v. Union Gas Co., 491 U.S. 1, 55-56 (1989) (White, J., concumng in part and dissenting in part).

246. See Vicki C. Jackson, One Hundred Years of Folly: The Eleventh Amendment and the 1988 Tem. 64 S. CAL. L. REY. 51, 85-86 n.150 (1990).

247. 491 U.S. at 29 (Scalia, J., concurring in part and dissenting in part).

248. 491 U.S. 223 (1989).

249. Id. at 233 (Scalia, J., concurring). 
Combining that position with his argument in Union Gas, ${ }^{250}$ later accepted by a majority in Seminole Tribe, ${ }^{251}$ that Congress lacks the power to abrogate Eleventh Amendment immunity under its Article I powers, we arrive at a position that is overall more protective of state sovereignty: Not only does Congress lack the power to subject the states to private suits in federal court, it lacks the power even to subject states to liability to private individuals except under the Fourteenth Amendment. ${ }^{252}$

That Justice Scalia views the Eleventh Amendment as bearing on more than just jurisdiction is further shown by his discussion of the abrogation issue in Blatchford v. Native Village of Noatak. ${ }^{253}$ Here, writing for a majority, Scalia chided the dissenting Justices for treating the Eleventh Amendment as if it were merely a matter of jurisdiction: "The fact that Congress grants jurisdiction to hear a claim does not suffice to show Congress has abrogated all defenses to that claim. The issues are wholly distinct."254 The Court's characterization of Eleventh Amendment immunity as a nonjurisdictional defense is, of course, in tension with the forum-allocation interpretation of the Eleventh Amendment.

\section{d. Hess Again}

The Court's reliance on the idea that a purpose of the Eleventh Amendment is to protect state treasuries is not the only aspect of the Hess opinion that conflicts with the forum-allocation view. There is, in addition, dictum in the opinion that directly contradicts that interpretation of the Eleventh Amendment. Although I have eschewed any reliance on dicta so far, I have made an exception for the Hess dictum because it is so recent and because it reflects the views of the Justices who dissented in Seminole Tribe.

The Court in Hess began its discussion of the Eleventh Amendment by noting that "[t]he Eleventh Amendment largely shields States from suit in federal court without their consent, leaving parties with claims against a State to present them, if the State permits, in the State's own tribunals."25s Read literally, this sentence supports the immunity-from-liability interpretation even more directly than does the "assent" language in McKesson or the "consent"

250. See Union Gas, 491 U.S. at 36-45 (Scalia, J., concurring in part and dissenting in part).

251. 116 S. Ct. 1114, 1131-32 (1996).

252. Even if we attributed the foregoing views to him, Justice Scalia would still arguably have been guilty of overlooking a technicality favoring the states. As explained below, if Eleventh Amendment immunity is both an immunity from lower federal court jurisdiction and an immunity from liability, then Scalia could have taken the position that a clear statement of an intent to abrogate the latter immunity should not enable an individual to bring suit in federal court unless Congress also clearly stated its intent to abrogate the former immunity. See infra notes $270 \& 272$.

253. 501 U.S. 775 (1996).

254. Id. at $786-87$ n.4.

255. Hess v. Port Auth. Trans-Hudson Corp., 115 S. Ct. 394, 400 (1994) (emphasis added). 
language in Seminole Tribe. These latter cases suggest that the states' consent to suit is a condition of the Supreme Court's appellate jurisdiction, but they do not intimate that states are free to refuse to entertain damage claims against themselves in their own courts. ${ }^{256}$ If the Eleventh Amendment did not protect the states from federal liability, and if Congress were to make states liable, then under the Supremacy Clause, the states would be required to enforce that liability. ${ }^{257}$ Hess's statement that states are free not to permit suits under federal law to proceed against themselves in their own courts ${ }^{358}$ is for this reason inconsistent with the forum-allocation interpretation. The statement would be true only if some legal principle protected the states from liability under federal law, not just from the jurisdiction of the lower federal courts. The Justices in the Hess majority appear to have regarded the Eleventh Amendment as embodying such a principle.

In evaluating the latter statement in Hess, however, it is important to keep in mind that the opinion was written during the reign of Union Gas by a Justice who later dissented from the Court's overruling of that decision. ${ }^{259}$ Indeed, only Justice Kennedy was in the majority in both Hess and Seminole Tribe. ${ }^{260}$ With the possible exception of Justice Kennedy, therefore, the Justices who expressed the belief in Hess that the Amendment protected the states from federal liability also believed that Congress had the power to subject the states to both federal liability and lower federal court jurisdiction. In other words, they viewed the protection afforded the states by the Eleventh Amendment as presumptive only. Given the Seminole Tribe majority's recasting of the Eleventh Amendment as a limitation on congressional power, it is open to question whether the members of the Hess majority (except perhaps Justice Kennedy) would feel bound to adhere to what was after all only dictum in that case, ${ }^{261}$ and by all appearances ill-considered dictum to

256. I maintain that the assent language in both McKesson and Seminole Tribe supports the immunityfrom-liability interpretation because, in the absence of Supreme Coun review. any federal liability of states would be illusory or at least ineffectual. My point here is that Hess supports the immunity-from-liability interpretation even more directly because it denies the obligation of states to entertan such cases even in their own courts.

257. The Court made this point in both Reich and Hilton, as did Justice Marshall in Employees. See supra Part II.

258. I am assuming that the Coun's statement applies to suits based on federal law, as the Hess action was itself a suit under federal law. See $115 \mathrm{~S}$. Cl. at 397 . I am also assuming that the adverb "largely" does not qualify the par of the sentence that indicates that the state is free not to permit a suit against itself to proceed in the state courts.

259. Justice Ginsburg wrote the opinion, which Jusuces Stevens. Kennedy. Souter, and Breyer joined. See Hess, 115 S. Ct. at 397.

260. There is nothing in the dissentung opinion in Hess indicaung that the dissentung Justuces ether agreed or disagreed with the statement that the states are free to close their courts to suits secking damages under federal law.

261. I am characterizing as dictum the statement that states can be sued in state court only "if the Stale permits." Hess, $115 \mathrm{~S}$. Ct. at 400 . The statement that the purpose of the Eleventh Amendment was to protect state treasuries was not dictum. Given the Justuces" conception of the Eleventh Amendment as subject to plenary congressional abrogation. however. the majonty's statements in that regard could be recast as a statement about the factors that determine which entitues qualify as the state for purposes of the 
boot. ${ }^{262}$ For this reason, I do not regard the Hess dictum to be nearly as probative of whether the current Court regards Eleventh Amendment immunity as immunity from liability as the statements in Seminole Tribe discussed above, statements by Justices who (except for Justice Kennedy) criticized the Hess majority for "underprotecting . . . state sovereignty." 263 But the dictum does show, at the least, that even the Justices least enamored of the Eleventh Amendment have not fully internalized the forum-allocation interpretation.

\section{Will}

One might read the Court's recent opinion in Will v. Michigan Department of State Police $e^{264}$ as a recognition that states enjoy two sorts of immunity from federal power, an immunity from the original jurisdiction of the lower federal courts and a separate immunity from liability. Yet the Court in Will clearly treated the states' immunity from liability as subject to abrogation by Congress. Will thus suggests the possibility that while the states enjoy an immunity from the original jurisdiction of the lower federal courts that is irrepealable by Congress under Article I, they enjoy only a presumptive immunity from liability under federal law. This would represent only a minor inroad on the forum-allocation interpretation. Will also offers a possible post hoc explanation of the decisions discussed in Section B: Might their references to the protection of state treasuries be understood as references to the rebuttable immunity from liability recognized in Will as opposed to a hypothetically irrepealable immunity from liability under the Eleventh Amendment? I conclude that this possible way to reconcile these cases with the forum-allocation interpretation is unconvincing.

Will was a suit brought against the state in the state courts under section 1983. ${ }^{265}$ The Court acknowledged that the Eleventh Amendment did not apply because the suit had been brought in the state courts. ${ }^{266}$ The issue was whether section 1983 made states liable in damages to private individuals. The Court held that whether a statute makes states liable in damages to individuals should be decided through the application of a clear statement rule identical in

immunity from liability recognized in Will v. Michigan Department of State Police, 491 U.S. 58 (1989). See infra Subsection III.B.4. With respect to the particular statute involved in Hess, however, the Court had already held (in Hilton) that the Will immunity from liability had been abrogated by Congress. See Hilton v. South Carolina Pub. Rys. Comm'n, 502 U.S. 197, 206-07 (1991) (affirming on stare decisis grounds that obligations imposed by FELA apply to states).

262. That the dictum was ill-considered is suggested by the fact that two of the Justices who concurred in the opinion (Stevens and Kennedy) had indicated just a few terms before that the states were required by the Supremacy Clause to entertain suits under FELA in their own courts. See Hilton, 502 U.S. at 207.

263. Hess, $115 \mathrm{~S}$. Ct. at 410 (O'Connor, J., dissenting).

264. 491 U.S. 58 (1989).

265. 42 U.S.C. $\S 1983$ (1994).

266. See Will, 491 U.S. at $63-64$. 
substance to the one that determines whether the Eleventh Amendment has been abrogated. ${ }^{267}$ The Court held that although the clear statement rule is not, strictly speaking, required by the Eleventh Amendment, it is supported by the Amendment and by the constitutional principles of federalism it exemplifies. ${ }^{268}$ The Court's decision in Will might be understood as a recognition of a quasi-constitutional immunity of states from liability to individuals, an immunity emanating in part from the Eleventh Amendment but based more broadly on constitutional principles of federalism, ${ }^{369}$ but an "immunity" subject to plenary congressional abrogation.

The Will holding may help reconcile some of the decisions discussed in this Part with the forum-allocation interpretation of the Eleventh Amendment. The statements in Edelman and its progeny-suggesting that because of the Eleventh Amendment, the states would remain free to decide whether or not to provide retrospective monetary relief-make sense if one assumes that the Court was referring here to the immunity from liability discussed in Will rather than a jurisdictional immunity. ${ }^{270}$ We might similarly try to reconcile the Court's statement in Hess that the purpose of Eleventh Amendment immunity is to protect state treasuries with the forum-allocation interpretation by recasting it as a statement about the purpose of the immunity from liability recognized in Will. The Will case may also provide a retrospective explanation

267. See id. at 65 .

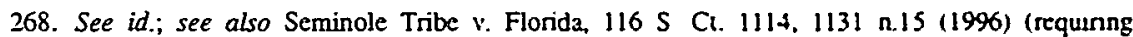
application of "clear statement" rule based on "principles of federahsm"). Hulton v South Carolina Pub Ry. Comm'n, 502 U.S. 197, 209 (1991) (O'Connor, J.. dissentung) ("The (Will) clear sutement nule is not a mere canon of statutory interpretation. Instead, it denves from the Constitution itself.")

269. Some may quarrel with calling the protection Will gave the states an "ummunity" if it is subject to plenary abrogation by Congress. I share this semantic concern. Nevertheless, dunng Unon Gas's bnef reign, the Eleventh Amendment was said to give the states an "Immunuty" even though the protecuon it provided had the force of a mere presumption. See Hess $v$ Port Auth. Trans-Hudson Corp. $115 \mathrm{~S} \mathrm{Cl}$. 394, 400 (1994). The Cour also refers to the protection afforded by the Eleventh Amendment as an "unmunty" even in contexts in which it is clearly subjea to abrogation. See Atascadero State Hosp. y Scanlon. 473 U.S. 234, 240 (1985) (requiring for finding of abrogation "an unequivocal expression of congressional intent to overtum the constitutionally guaranted immunity of the several stales") (citalions omitied). I shall accordingly refer to the Will decision as recognizing an "immunty" from liability. with the understanding that such "immunity" may be nothing more than a presumption that Congress has not crealed a labulily.

270. Other parts of the Edelman opinion, however, make sense only if the Coun was refernng to a jurisdictional immunity. For example, the Court said that the immunity "sufficiently partakes of the nature of a jurisdictional bar" that states can invoke it for the first time on appenl without waving ut. See Edelman v. Jordan, 415 U.S. 651,678 (1974). Of course, Will is consistent with the idea that the states possess both forms of immunity. The waiver issue discussed in Edelman presented the Coun whth one of the few situations in which an immunity from federal jurisdiction would retain any relevance when accompanied by a coextensive immunity from liability. Another area would be appealability. The Coun in Puerto Rico Aqueduct \& Sewer Authority v. Metcalf \& Eddy, Inc., 506 U.S. 139. 147 (1993), held that the denual of an Eleventh Amendment claim is immediately appealable, a holding that rests on a view of Elevenih Amendment immunity as an immunity from suit in federal coun as opposed to an immunity irom labulty The Court's express statements that Eleventh Amendment ummunity is an ummunty from sust do not contradict the claim that it is also an immunity from liability. Cf. Gould. Inc. v. Pechuney Lgune Kuhlmann. 853 F.2d 445, 449-51 (6th Cir. 1988) (holding that denial of foreign sovereign immunty elaum ts immediately appealable (consistent only with conclusion that foreign sovereign immunty is immunily from suit) and that privatization of defendant company does not depnve company of tis enutlemen! to ummunity (consistent only with conclusion that foreign sovereign immunty is immunity from habultyy)) 
of the abrogation decisions in which the Court sought evidence of a congressional intent to make states liable to private parties. Under Will, abrogation of immunity from liability is governed by the same clear statement rule as abrogation of immunity from federal jurisdiction, and, of course, if there is no liability, the suit must be dismissed. The Court thus could have properly dismissed the claim in Dellmuth $v . M u t h^{271}$ on the ground that Congress had not abrogated the states' immunity from liability. ${ }^{272}$

But there is little in these opinions to support such a reading. The states' obligation to provide the retrospective relief at issue in the Edelman line of cases had clearly been made a condition of the states' receipt of federal funds by the time Green was decided, so under the forum-allocation view (even as modified in Will) the state courts would have been required to provide a forum in which to recover that relief. Yet the Court treated the absence of original federal jurisdiction as the equivalent of denying the states' obligation to afford such relief. Congress's power to condition the receipt of federal funds on the undertaking to provide retrospective relief was (and is) not in doubt. Congress could clearly have made submission to suit in federal court a condition as well. The Court's apparent assumption that the state court was nevertheless under no enforceable federal obligation to afford the relief sought is inconsistent with the forum-allocation view. It is possible, I suppose, that the Green Court overlooked the fact that the statute and regulations at issue imposed on the states an obligation to afford retrospective relief. The fact remains that the Court equated the lack of original federal jurisdiction with the freedom of states to deny retrospective relief, and this form of analysis is simply inconsistent with the forum-allocation view. ${ }^{273}$

It is even more difficult to explain Hess as a decision about the immunity from liability involved in Will. First, Will preceded Hess, yet the Court did not frame the issue in Will terms. Second, the Court had already held in Hilton that states were liable in damages to individuals for violations of FELA. Indeed, the holding of Hilton, one of the trio of cases supporting the forumallocation view, only serves to heighten the conflict between the forumallocation position and the Hess Court's statements that the Eleventh

271. 491 U.S. 223 (1989).

272. The reverse, however, is not necessarily true: If there are two immunities, then abrogation of the immunity from liability does not mean that immunity from lower federal court jurisdiction has been abrogated. Thus, Will does not explain the Court's exclusive focus in Union Gas on Congress's intent to impose liability on the states.

273. See supra note 216. That there was no question about Congress's power to require the states to pay retrospective relief as a condition of receiving federal funds suggests that those cases may be even more at odds with the forum-allocation view than I suggested above. Perhaps the decisions should be taken as holding that state courts cannot be obliged to entertain suits against themselves in their own courts even where Congress concededly has the power to abrogate Eleventh Amendment immunity from fedcral court jurisdiction. If so, then Congress's only option to "enforce" the Fourteenth Amendment in any meaningful way would be to subject the states to suit in federal court. Congress would not have the option of subjecting states to liability and obligating the state courts to enforce that liability. 
Amendment seeks to protect state treasuries and that states are free to deny a state forum.

At any rate, this explanation of Hess and the Edelman line of cases reconciles them with the forum-allocation interpretation of the Eleventh Amendment only by recognizing an immunity from liability that has its source outside the Eleventh Amendment. The reconciliation is semantic only and is, in any event, problematic because: (1) "Eleventh Amendment immunity" does not really have its source in the Eleventh Amendment; ${ }^{274}$ and (2) the immunity from liability recognized in Will rests to some extent on the Eleventh Amendment. ${ }^{275}$ Saying that there are two immunities, one from liability and one from jurisdiction, does not much advance the analysis. The question is whether there is any meaningful difference between the immunity from liability recognized in Will and the immunity from liability arguably recognized in Seminole Tribe, and this question, in turn, depends on the scope of Congress's power to abrogate the Will immunity.

The Court in Will treated the states' immunity from liability as subject to plenary abrogation by Congress. Under the then-prevailing Union Gas regime, Eleventh Amendment immunity was subject to abrogation by Congress pursuant to any of its legislative powers. Thus, under Union Gas, the two immunities were in substance identical as far as congressional power was concerned: Both amounted only to a rule of clear statement. Seminole Tribe holds that Eleventh Amendment immunity may be abrogated by Congress only pursuant to the Fourteenth Amendment. ${ }^{276}$ This holding would not have produced any difference between the two immunities as applied to the facts of the Will case, as the plaintiff in that case sought to enforce an obligation imposed on the states by the Fourteenth Amendment and relied on a statute enacted by Congress pursuant to that Amendment. ${ }^{2 \pi}$ With respect to statutes not enacted pursuant to the Fourteenth Amendment, the issue arises whether the two immunities continue to be identical. In other words, does the Courts holding in Seminole Tribe that the states' Eleventh Amendment immunity may not be abrogated under Article I extend to the quasi-constitutional immunity from liability recognized in Will? Or does the latter immunity continue to be merely presumptive, subject to abrogation by Congress pursuant to any of its

274. See supra note 6 .

275. See supra note 268 and accompanying text.

276. See Seminole Tribe v. Florida, 116 S. Ct. 1114, 1124-25 (1996).

277. See Parratt v. Taylor, 451 U.S. 527. 554 n.13 (1981) (Powell. J., concurring) ("Secuon 1983 was enacted in 1871 as one of the statutes intended to implement the Fourteenth Amendment.") The Court held in Maine v. Thiboutot, 448 U.S. I (1980), that section 1983 supplies a remedy as $u$ ell agaunst state officials who violate federal statutes not relating to civil rights. See 448 U.S. at 10-11. With respect to clums brought under section 1983 to enforce obligations of the state under starutes enacted under Article I. Congress's power to abrogate the immunity from liability would be broader than its pouer to abrogate immunity from lower federal cour jurisdiction, if one interpreted Eleventh Amendment Immunity as merely the latter type of immunity. 
legislative powers? Put otherwise, did the Court in Seminole Tribe recognize an immunity of the states from liability that may not be abrogated by Congress under Article I? If the Court was serious in Seminole Tribe that the Supreme Court's jurisdiction over state court suits against states depends on the state's consent to the suit, then the Court has denied Congress the power effectively to abrogate the Will immunity from liability under Article I.

\section{THE ABROGATION REDUCTIO AND MCKESSON'S UNRAVELING}

Examination of another conundrum posed by Seminole Tribe will help point the way to a resolution of the conflict between Seminole Tribe and McKesson concerning the nature of Eleventh Amendment immunity. Although there may at first seem to be little connection between the problem examined in this Part and the one discussed in the prior sections, our discussion will show the two to be closely linked.

In Seminole Tribe, the Court held that Congress has the power to abrogate Eleventh Amendment immunity pursuant to its power to enforce the Fourteenth Amendment, but not under its Article I legislative power. The Fourteenth Amendment, however, includes a clause prohibiting states from depriving persons of property without due process of law. Can Congress pass a statute giving individuals a property right vis-à-vis the states and then, to "enforce" the Due Process Clause, abrogate the states' Eleventh Amendment immunity with respect to suits to enforce that right? An affirmative answer to this question threatens to reduce Seminole Tribe's abrogation holding to nothing. I call this the abrogation reductio.

Section A of this Part elaborates on the abrogation reductio and shows its surface plausibility. Section B considers and rejects possible doctrinal modifications the Court might adopt to avoid the reductio. Section $\mathrm{C}$ continues the search for an escape from the reductio by pressing into service the Court's procedural due process jurisprudence, of which McKesson forms an integral part. This analysis shows three things: First, the conflict between McKesson and the immunity-from-liability interpretation of the Eleventh Amendment is much deeper than it appeared in Part I. Second, the Court's procedural due process doctrine offers a rationale for escaping the abrogation reductio. This escape may depend on the Court's rejection of some of its broader precedents concerning the scope of Congress's Section 5 enforcement power, or its willingness to find such precedents inapplicable where the right being "enforced" is a procedural one, but one or both of these possibilities seems likely. Because this rationale for escaping the reductio (relying as it does on McKesson) succeeds only if the forum-allocation interpretation is right, the prospect of escaping the reductio thus offers a substantial reason for preferring that interpretation. But, at the same time (and this is the third point), our 
analysis also exposes significant doctrinal problems with the Cour's procedural due process jurisprudence and with McKesson in particular. These doctrinal problems cast considerable doubt on the plausibility of the traditional reading of the McKesson decision, and as a consequence they leave the forumallocation interpretation on significantly weaker ground.

\section{A. The Abrogation Reductio}

The complex and highly problematic relationship between McKesson and Seminole Tribe's abrogation holding is best understood by giving further consideration to Congress's post-Seminole Tribe power to give patent holders a right to obtain damages in federal court from states that infringe. After the Court's Atascadero decision, Congress amended the patent laws to make clear: (1) that the primary obligations that the patent laws impose do apply to state governments; (2) that states that infringe patents are liable in damages to the patent holders; and (3) that patent holders may obtain those damages in federal court. ${ }^{278}$ The Senate Report accompanying the Patent and Plant Variety Protection Remedy Clarification Act indicates that Congress believed that it had the power to abrogate the states' Eleventh Amendment immunity under Article I. ${ }^{279}$ But, perhaps anticipating the Seminole Tribe decision, the Report covered its bases and relied further on the idea that Congress has the power to abrogate the states' Eleventh Amendment immunity in patent cases under Section 5 of the Fourteenth Amendment. ${ }^{250}$ The Report indicates that patents are property and thus implicate the Fourteenth Amendment's Due Process Clause. ${ }^{281}$ The reasoning appears to be that the existence of a "property"

278. See Patent and Plant Variety Protection Remedy Clanficauon Act. 35 U.S C $\$ \$ 271.296$ (1994) Congress passed similar laws relating to trademarks and copynghts. See Trademark Remedy Clanfication Act, 15 U.S.C. $\$ \S 1122,1125,1127$ (1994); Copyright Remedy Clanficauon Act. 17 U S C $\$ 511$ (1921)

279. See S. REP. NO. 102-280, at 7-8 (1992).

280. See id. (expressiy relying on "the Patent Clause. the Commerce Clause, and the enforcement provision of the fourteenth amendment").

281. See id. at 8 \& n.55. The Repor cited the distnct coun dectsion in Lemelson v Ampex Corp 372 F. Supp. 708 (N.D. Ill. 1974), for the proposition that patents are properyy. In that ease. the cour suggested that patents were property for purposes of the Takings Clause and that, accordingly, a nght to compensanon exists under that Clause if states infringe. See Lemelson. 372 F. Supp. at 710-13 This suggestion is problematic. Although the Court has interpreted the term "property" in the Talungs Clause more narrowly" than the same term in the Due Process Clause, it may be conceded that patents may consutute property for purposes of the Takings Clause. Cf. Ruckelshaus v. Monsanto Co., 467 U S 986. 1002-04 (1984) (finding that trade secrets are propeny for purposes of Takings Clause). But the Coun's takings cases would appear to require the conclusion that a state's infringement of a patent is not a "taking." as $t$ does not "virually destroy" the propeny"s value. See TRBBE, supra note 175, \$9-3, at S93. Patent infingement is akin to the tort of unfair competition, and the Cour has distingusshed takings from ordinary tons See Pruneyard Shopping Crr. v. Robins, 447 U.S. 74, 82 (1980) (")[N]al every destructuon or injury to propeny by governmental action has been held to be a 'taking' in the constitutional sense ") (quoting Armstrong v United States, 364 U.S. 40, 48 (1960)): Omnia Commercial Co v. Uniced States. 261 L: S 502. 508 (1923) ("[D]estruction of, or injury to, property is frequently accomplished without a 'taking" in the consututional sense."); National By-Prods., Inc. v. United Stales. 405 F.2d 1256, 1275 (Ct. Cl 1969) ("IT)he Govemment's foreknowledge will not conven an otherwise insufficient injury into a taking As most "t 
right under the Due Process Clause gives rise to a congressional power to abrogate the states' Eleventh Amendment immunity with respect to that property. ${ }^{282}$

If this reasoning were to hold, then Congress's power to abrogate Eleventh Amendment immunity would appear to be coextensive with its power to legislate under Article I, and, if so, Seminole Tribe's holding that Congress lacks the power to abrogate Eleventh Amendment immunity under Article I would be eviscerated. This would be so whether we regarded the Eleventh Amendment as a forum-allocation principle or as conferring an immunity from liability. Suppose that the Amendment is a forum-allocation principle. By hypothesis, Congress would have the power to: (1) prohibit states from infringing patents; and (2) require them to pay damages to the patent holder if they do infringe. It seems clear that the patent holder's right to damages is a "property" right for purposes of the Due Process Clause. There is no doubt

could strengthen the plaintiff's case in a tort action."). As discussed below, the term "property" in the Due Process Clause has been construed by the Court in such a way as to encompass any statutory entitlement vis-à-vis the state, and a state "deprives" persons of that property whenever it injuses the property interest intentionally. Cf. Daniels v. Williams, 474 U.S. 327, 332-36 (1986) (holding that negligent conduct cannot give rise to "deprivation" of property for purposes of Due Process Clause). The Senate Report does not cito the Takings Clause; it relies only on the Due Process Clause.

282. Two courts have considered the validity of this abrogation. In College Savings Bank v. Florida Prepaid Postsecondary Education Expense Board, No. 95-4516, 1996 U.S. Dist. LEXIS 18817 (D.N.J. Dec. 13, 1996), the plaintiff raised a patent infringement claim under the Patent Act and a false advertising claim under the Lanham Act against a state agency. The court upheld Congress's abrogation of the states' Eleventh Amendment immunity under the Patent Act, but not under the Lanham Act. With respect to the patent infringement claim, the court wrote that "if rights protected by the Patent Act are correctly considered 'property,' legislation making the states liable in federal court for violating that statute would 'plainly' be 'appropriate' for enforcing the Fourteenth Amendment." Id. at 76. The court went on to conclude that patents are indeed property, relying primarily on cases stating that they are. See id. at 77-79. On the other hand, the court found that the right to be free from competition based on false advertising was not a property right, relying on the absence of cases calling such a right a property right. See id. at 88-95. On this latter conclusion, see infra note 289.

In Genentech, Inc. v. Regents of the University of California, 939 F. Supp. 639, 643 (S.D. Ind. 1996), mandamus granted on other grounds sub nom. In re Regents of University of California, Misc. No. 471, 1996 U.S. App. LEXIS 30617 (Fed. Cir. Nov. 14, 1996), the court relied on the above-quoted passage from the Senate Report and, in dictum, accepted the Fourteenth Amendment/due process abrogation theory. The court held that although Congress could on this theory validly abrogate the states' Eleventh Amendment immunity from patent infringement claims by holders of federal patents, it could not subject states that hold federal patents to declaratory judgment actions by individuals seeking a declaration of the patent's invalidity. The patent holder has "a protectable property right and to permit the State to infringe that property right without redress for the patent owner would deprive that owner of property without due process of law." Id. But someone seeking a declaration that a patent is invalid, the court said, "has no protectable property right of which it . . . has been deprived without due process of law." Id. That is because that person "is free to manufacture said substances until [the patent holder] not only lodges an infringement action, but also secures either injunctive relief or final judgment in its favor [, and,] [i]n either event, [it] will have gotten due process of law before a deprivation occurs." Id. at 643-44. That may be true, but, as discussed below, a patent holder does not necessarily suffer a deprivation of property without due process of law just because his patent has been infringed by the state. If the infringement was "random and unauthorized," the state would satisfy due process simply by making a postdeprivation state remedy available. See infra text accompanying notes $321-39$. It is accordingly not as clear as the court seemed to think that the patent holder and the person claiming that the patent is invalid stand in different positions with respect to Congress's abrogation power. Both arguably have property interests that Congress may (or may not) have the power to protect by abrogating Eleventh Amendment immunity. 
that "property" can be created by federal statute for purposes of that Clause. ${ }^{283}$ The Court has found that the right to continue receiving an uninterrupted stream of money payable in the future uriggers due process protection. ${ }^{284}$ If so, then there can be little doubt that the right to receive money presently owing (which is by definition what the right to damages is) is also a property right. On the Senate's reasoning, the existence of this property right brings the Fourteenth Amendment's Due Process Clause into the picture and gives rise to a congressional power to abrogate the states' Eleventh Amendment immunity, which (as we are assuming the correctness of the forum-allocation interpretation) means that Congress can give the lower federal courts jurisdiction to entertain suits seeking such damages from the states. If the power to abrogate this immunity hinges only on the existence of a right to damages, and if Congress's power to subject states to damage liability is coextensive with its power to impose obligations on them (a tenet of the forum-allocation theory), then Congress's power to abrogate Eleventh Amendment immunity is coextensive with its power to legislate under Aricle $\mathrm{I}$ as delineated in such decisions as New York $v$. United States. ${ }^{28 s}$

The problem does not go away if we assume that the Eleventh Amendment immunizes the states from damage liability to individuals. On the Senate's reasoning, this immunity can be abrogated as long as individuals have a property right vis-à-vis the states. The Senate Report states that a patent is a property right for purposes of the Due Process Clause, and it concludes that the existence of this right gives Congress the power to abrogate Eleventh Amendment immunity. ${ }^{286}$ If we assume that Eleventh Amendment immunity is immunity from liability, then Congress's creation of a property right in a patent, on the Senate's reasoning, gives rise to a congressional power to subject states that infringe to liability in damages to patent holders. Again, this proves too much. The Senate is probably correct in concluding that a patent is property for purposes of the Due Process Clause. Under the Court's current approach to this subject, whether a statute establishes a property right turns on whether the statute places mandatory limits on a state's discretion to act

283. See, e.g., Mathews v. Eldridge, 424 U.S. 319 (1976) (involving propeny interest in conunued receipt of disability benefits under Social Security Act): Amett v. Kennedy. 416 U.S. 134 (1974) (Involving property interest in continued employment with federal agency. an interest created by federal statute): Goldberg v. Kelly, 397 U.S. 254 (1970) (involving property interest in continued receipt of financtal and under Aid to Families with Dependent Children program); see also Henry Paul Monaghan, Of "Liberry" and "Property", 62 CORNELL L. REV. 405, 435 n. 194 (1977).

284. In Goldberg, 397 U.S. at 262, and Eldridge, 424 U.S. at 332, the Coun found a property nght in the continued receipt of money not yet due.

285. 505 U.S. 144 (1992).

286. If the Senate had adhered to the forum-allocation vew, II would not have had to hang its hat on the idea that a patent is property for due process purposes. The fact that it did may suggest thal 4 understood the Eleventh Amendment to protect the states from damage liability: that is, it believed its power to abrogate was a power to subject states to damage liability. 
towards the putative property holder. ${ }^{287}$ So if Congress prohibits states from infringing patents, then patent holders have a property right in states' not infringing their patents. The problem, of course, is that Congress's power to place mandatory obligations on the states is coextensive with its power under Article I to make its laws applicable to the states. If Congress has the power to abrogate Eleventh Amendment immunity whenever it has the power to place mandatory obligations on states towards individuals, ${ }^{288}$ then Congress's power to abrogate Eleventh Amendment immunity has, again, been made coextensive with its power to legislate substantively with respect to the states under Article I, as construed in such cases as New York and Garcia. If so, Seminole Tribe's abrogation holding has been reduced to nothing. ${ }^{289}$

287. See, e.g., Cleveland Bd. of Educ. v. Loudermill, 470 U.S. 532, 538-39 (1985). In Sandin v. Conner, 115 S. Ct. 2293, 2297-99 (1995), the Court described this as the approach adopted by its recent decisions concerning "liberty" interests, but then proceeded to depart from it in the context of prisoners' rights. The Court recognized, however, that the prevailing approach "may be entirely sensible in the ordinary task of construing a statute defining rights and remedies available to the general public." Id. at 2299. In any event, the Court did not purport to alter its approach to finding property interests.

288. That the obligation be an obligation toward individuals is a potentially significant qualification. Clearly an obligation not to infringe someone's patent satisfies it, as does the obligation to pay the person damages. It is possible that the state's obligation not to pollute the water or air does not give anyone a "property" right. Perhaps it would. The requirement that the obligation be toward individuals would appear to make relevant much of the Court's standing jurisprudence. It may be the case that Congress's power to give individuals a "property" right is coextensive with its power to give individuals standing to seek injunctive relief. Cf. Cass R. Sunstein, What's Standing After Lujan? Of Citizen Suits, "Injuries," and Article III, 91 MiCH. L. REV. 163, 234 (1992) (suggesting that Congress might confer citizen standing to enforce environmental obligations by providing by statute that "all Americans have a kind of property right-a tenancy in common-in some environmental asset").

289. The abrogation reductio was perceptively noted by the district court in College Savings Bank $v$ Florida Prepaid Postsecondary Education Expense Board, No. 95-4516, 1996 U.S. Dist. LEXIS 18817 (D.N.J. Dec. 13, 1996). The court there ruled that Congress's abrogation of Eleventh Amendment immunity in the Lanham Act was not a valid exercise of its Section 5 power, at least as applied to a false advertising claim. (The court noted that false advertising claims are separate and distinct from trademark infringement claims. See id. at *88 n.25.) The court reasoned as follows:

[W] are unaware of any authority suggesting that Congress may, by simple fiat, abruptly declare that a simple statutory cause of action, which traditionally has not been understood to involve any kind of property, now encompasses a "property right" to which the Fourteenth Amendment applies. Indeed, if Congress has such power, it could easily "reverse" the outcome in Seminole Tribe by inserting into some staff report a reference regarding the importance of using the Fourteenth Amendment to protect the "right" to have a state negotiate over a gaming compact. To quote Justice Scalia, "If state sovereign immunity has any reality, it must mean more than this."

Id. at *93-94 (quoting Pennsylvania v. Union Gas Co., 491 U.S. 1, 44 (1989) (Scalia, J., concurring in part and dissenting in part)). The court nevertheless found that the abrogation of immunity in the Patent Act was valid under Section 5 because patents are property. The court based these divergent results on the existence of statements in prior decisions recognizing that the right to be free of infringement of patents is a property right, and the absence of statements in prior decisions recognizing that the right to be free of compctition based on false advertising is a property right. The court, however, did not discuss the cases that set forth the test for defining "property" under the Due Process Clause. Although the court's concern that a contrary holding would reduce Seminole Tribe's abrogation holding to nothing is consonant with the concerns raised by this Article, the reasons the court gave for distinguishing patent infringement claims from false advertising claims are not entirely satisfying. 


\section{B. Avoiding the Reductio by Adjusting Constitutional Doctrine}

As the Senate's conclusion cannot coexist with Seminole Tribe's holding that Congress lacks the power to abrogate Eleventh Amendment immunity under its Article I powers, something has got to give. This Section considers possible doctrinal adjustments the Court could make to avoid the reductio without rejecting Seminole Tribe's abrogation holding. It turns out that avoiding the reductio in this fashion either would require adjustments too dramatic to contemplate or would be inconsistent with other parts of Seminole Tribe.

First, and most dramatically, the Court could reverse its holding in Fitzpatrick v. Bitzer ${ }^{290}$ that Congress has the power to abrogate Eleventh Amendment immunity under the Foureenth Amendment. The Cour's reasoning in Fitzpatrick, in fact, seems inconsistent with the Seminole Tribe result, as Justice Brennan pointed out in Union Gas, ${ }^{291}$ and as diversity theorists have noted as well. ${ }^{292}$ The Fitzpatrick reasoning should have led the Court to recognize an abrogation power under Aricle I for the same reason that Hamilton's reasoning in the Federalist Papers should arguably have led the Court in Hans to adopt the diversity interpretation. ${ }^{293}$ The rather skeletal analysis in Fitzpatrick stressed that the Fourteenth Amendment imposed significant obligations on the states, and the Court concluded from that premise that the Fourteenth Amendment gives Congress the power to subject states to damage actions in federal court if Congress regards such actions as necessary to enforce those obligations. ${ }^{294}$ The Court thus appears to have reasoned that the existence of a constitutional obligation of the states, combined with a congressional power to "enforce" those obligations by legislation, adds up to a congressional power to abrogate Eleventh Amendment immunity. This analytical jump from the existence of a primary obligation to a congressional power to abrogate Eleventh Amendment immunity would, of course, produce the very same result under provisions of the Constitution antedating the Fourteenth Amendment. For example, the Constitution as originally adopted included a Contracts Clause, ${ }^{295}$ which, as interpreted in Fletcher v. Peck, ${ }^{2 \%}$ forbids the states from impairing the obligation of its own contracts with individuals. ${ }^{297}$ The Court's analysis in Fit-patrick would support the

290. 427 U.S. 445 (1976).

291. See 491 U.S. 1, 17-18 (1989) (arguing that reasoning of Scalıa's dissentung opinion in linion Gas, which was ultimately embraced in Seminole Tribe, would be inconsistent with Court's holding in Fitzpatrick).

292. See Field, Congressional Imposition, supra note 58, at 1230.

293. See supra note 230.

294. See 427 U.S. at 456.

295. U.S. CONST. art. I, $\S 10 . \mathrm{cl} .1$.

296. 10 U.S. (6 Cranch) 87 (1810).

297. See id. at 136-39. 
conclusion that the Contracts Clause, perhaps as supplemented by the Necessary and Proper Clause, ${ }^{298}$ empowers Congress to subject states to both damage liability and federal court jurisdiction in order to enforce that obligation. The same analysis would support the conclusion that Congress has the power to subject the states to damage liability and federal court jurisdiction whenever it has the power to impose primary obligations on the states. Because the Court declined to recognize such a power in Seminole Tribe, the latter decision appears to be a rejection of the Fitzpatrick analysis.

The Court in Seminole Tribe took pains not to call into question the Fitzpatrick result. There probably are rationales for sustaining a congressional power to abrogate Eleventh Amendment immunity under the Fourteenth Amendment that do not support the same abrogation power under antecedent constitutional provisions. Such a rationale would no doubt have to rely heavily on the idea that federal-state relations were fundamentally altered by the Civil War Amendments, something the Court emphasized in Fitzpatrick. ${ }^{299}$ But, while this basic alteration may be necessary to support the Seminole Tribe holding, it is not sufficient. First, it does not supply us with a basis for concluding that one of the alterations made was the establishment of a congressional power to make states liable to individuals and to subject states to suit in federal courts. ${ }^{300}$ Second, even if we had a basis for such a conclusion, we would still lack a reason for denying that the Fourteenth Amendment authorizes the exercise of this power for the purpose of enforcing the primary obligations imposed on the states by Congress under its Article I powers. Just as the Fourteenth Amendment's Due Process Clause has been construed to incorporate much of the Bill of Rights, ${ }^{301}$ the same Clause might reasonably have been construed to incorporate Congress's Article I powers for abrogation purposes. ${ }^{302}$ It is conceivable that the Court will so hold when confronted with the abrogation reductio, but this would mean rejecting Seminole Tribe's holding that Congress may not abrogate under Article I. If we take seriously Seminole Tribe's abrogation holding and the Court's indication that it does not mean to reject Fitzpatrick insofar as it held that Congress may abrogate Eleventh Amendment immunity to enforce the Fourteenth Amendment, we will have to look elsewhere for an escape from the abrogation reductio.

The Court could try to avoid the reductio by reversing what remains of Garcia. By taking away Congress's power to place primary obligations on the states under Article I, the Court would deny Congress the power to create

298. U.S. CONST. art. I, $\S 8$, cl. 18.

299. 427 U.S. at $455-56$.

300. See Fletcher, Historical Interpretation, supra note 7, at 1115-16.

301. See Geoffrey R. StONe et Al., Constitutional Law 804-13 (3d ed. 1996).

302. See JACOBS, supra note 42, at 163-64 (suggesting that Due Process Clause of Fourteenth Amendment is "potential basis for renouncing [Eleventh Amendment] doctrine"). 
correlative property rights, and hence, it would cut the reductio off at its inception. The Court has already begun cutting back on Garcia, but as noted, New York left Congress the power to impose obligations on the states so long as the obligations are imposed on nonstate actors as well. ${ }^{303}$ Denying Congress all power to impose obligations on the states would limit Congress's powers vis-à-vis the states even more drastically than the pre-Garcia cases did, for those cases conceded Congress the power to impose obligations on the states in areas not traditionally regulated by the states. ${ }^{304}$ Patent, copyright, and bankruptcy would probably fall into this category. Resurrecting the National League of Cities standard may indeed strike the Court as an attractive way to avoid the reductio, as it would permit Congress to subject the states to liability and suit in federal court at the behest of patent holders without sweeping in all of Congress's Article I powers. The statute at issue in Seminole Tribe, however, could probably have been voided on the merits for failing even the New York test. ${ }^{305}$ The statute imposed on the states and no one else the duty to negotiate in good faith with Indian tribes concerning gambling. ${ }^{306}$ It thus singled out states for regulation in a way that New York appeared to prohibit. The Court in Seminole Tribe nevertheless pointedly reserved the question of the statute's substantive validity. ${ }^{307}$ It may well be that the Justices in the Seminole Tribe majority would like to place additional limits on Congress's power to place substantive obligations on the states. This would certainly be the cleanest way to avoid the reductio, but given the Court's reservation of this issue, its decision to strengthen the Eleventh Amendment is not explained by its desire to scale Garcia back further.

Third, the Court could reconsider the test for defining "property" for purposes of the Due Process Clause. The Cour has recently shown a willingness to redefine liberty, ${ }^{308}$ and it could well do the same for property, but avoiding the reductio in this way would require dramatic doctrinal changes.

303. See supra text accompanying note 99.

304. See supra text accompanying note 96.

305. See Monaghan, supra note 34, at 119-20. It might perhaps be contended that IGRA is valid under New York on the theory that it gives the states a choice between: (1) negouating in good faith with Tribes, and (2) subjecting themselves to preemptive federal legislation. See New York v. Unted Stales. $50 S$ U.S 144, 173-74 (1992) (upholding federal law giving states choice between complying with federal directive or "having state law pre-empted by federal regulation"). If this had been a possible ground for upholding the federally imposed obligation to negotiate, then it is not clear why it would not also have been a basis for upholding the jurisdiction of the federal cour. The Eleventh Amendment does not bar federal jurisdiction over states that consent. If the fact that states remanned free to refuse to negotuate and to accept instead a preemptive federal law means that states were not being "commandeered," but only "encouraged." to negotiate with the Tribe, then it is not clear why the existence of this opuon did not also mean that the state was merely being "encouraged" to consent to federal jurisdiction. The Courn appears to have read the statute as imposing federal jurisdiction on the states, and if so. then the statute stmilarly must be read as imposing the duty to negotiate. Such commandeering of states would appear to be prima facie invalid under New York.

306. See Seminole Tribe v. Florida, 116 S. Ct. 1114. 1119 (1996).

307. See id. at 1126 n.10.

308. See supra note 287. 
Recall that if the forum-allocation interpretation of the Eleventh Amendment were right, Congress would have the power not only to prohibit the states from infringing patents but also to obligate them to pay damages to the patent holder. The right to damages is among the least controversial of property rights under the Due Process Clause. ${ }^{309}$ It is difficult to conceive of a redefinition of "property" that would exclude this right from the scope of the Due Process Clause without wreaking great havoc on due process doctrine.

If the immunity-from-liability interpretation were right, then Congress would have the power to place mandatory obligations on the states (so long as they are also placed on nonstate actors carrying out the same activities), but not to subject states to damage liability to individuals. The reductio on this assumption would rest on a definition of property that turned on the existence of mandatory state obligations towards individuals. It is not inconceivable that the Court would shift gears in this area and define property in such a way as not to include every mandatory state obligation towards individuals. Perhaps it could define the concept of property for due process purposes as it does in the context of the Takings Clause, so that it includes only legal rights closely analogous to common law property rights-interests, for example, that are broadly alienable at the option of the property holder. ${ }^{310}$ Such an approach may, indeed, allow the Court to accept a congressional power to abrogate Eleventh Amendment immunity in patent cases without sweeping in all of Congress's other Article I powers. Exactly what this alternative doctrinal universe would look like is pure speculation at this point, but it would certainly require the rejection of a great deal of precedent, for it would have to exclude from the scope of "property" such statutorily conferred and notfreely-alienable rights as the right to continued receipt of welfare payments and the right to continued employment if specified conditions are met. ${ }^{311}$ Whether the Court would go to such lengths just to save Seminole Tribe's abrogation holding is certainly subject to question.

As noted, this escape from the reductio would work only if the Court also rejected the forum-allocation interpretation of the Eleventh Amendment. In this respect, therefore, our search for an escape from the reductio supplies us with some slight additional support for the immunity-from-liability interpretation. But this escape from the reductio is ultimately unsatisfying. To adjust the constitutional definition of property to the extent required to accommodate

309. See supra note 284 and accompanying text.

310. See Loretto v. Teleprompter Manhattan CATV Corp., 458 U.S. 419, 435 (1982); United States v. General Motors Corp., 323 U.S. 373, 378 (1945) (describing property rights in physical thing as "denot[ing] . . . the right to possess, use and dispose of it"). See generally TRIBE, supra note 175 \$ 9-7, at 607-13 (discussing Cour's "deference to common-law conceptions of propeny" in takings area).

311. See Mathews v. Eldridge, 424 U.S. 319, 332 (1976) (recognizing right to receive Social Security disability payments); Amett v. Kennedy, 416 U.S. 134, 151-52 (1974) (recognizing right to continued Civil Service employment); Goldberg v. Kelly, 397 U.S. $254,262 \&$ n.8 (1970) (recognizing right to receive welfare payments not yet due). 
Seminole Tribe's abrogation holding would surely be to let the tail wag the dog. If doctrinal adjustments are required, the definition of property in the Due Process Clause seems like a poor choice. Although the Cour's definition of property cannot be said to be universally admired, adjusting it in the direction that would be required to avoid the reductio would move the doctrine in this area in exactly the wrong direction. ${ }^{312}$

\section{McKesson and the Abrogation Reductio}

McKesson and related procedural due process cases offer a more promising escape from the abrogation reductio. Examination of McKesson's relation to this issue allows us, in addition, to appreciate that the conflict between McKesson and the immunity-from-liability interpretation of the Eleventh Amendment runs far deeper than it at first appeared. Unsurprisingly, given the deep incompatibility of McKesson with the immunity-from-liability interpretation, escaping the reductio by relying on McKesson requires the rejection of the immunity-from-liability interpretation. But, at the same time, this analysis reveals problems with the conventional understanding of McKesson's holding that cast doubt on its plausibility. In the next Part, I will suggest a possible reinterpretation of McKesson that would save what I regard as its key insight. This reinterpretation, however, removes McKesson and Reich from the ranks of the cases supporting the forum-allocation interpretation, thus weakening significantly the doctrinal case for the forum-allocation interpretation.

\section{Avoiding the Reductio by Relying on McKesson and Related Procedural Due Process Cases}

McKesson is of course relevant to the abrogation reductio because, in addition to interpreting the Eleventh Amendment, the Court rendered an important due process holding. As discussed in Part II, McKesson's due process holding provides an important a link in the chain of reasoning underlying the forum-allocation interpretation. The Cour in McKesson held that, when the state does not give a taxpayer an opportunity to challenge a tax's conformity with law before paying the tax, the Due Process Clause requires the state to offer a postpayment opportunity to challenge the tax's validity, and, if the tax turns out to have been invalid, a remedy sufficient to cure the violation. ${ }^{313}$ Often, the constitutionally required remedy will be a

312. The Court's previous attempts to avoid undesired results by narrowing the definition of "liberty" and "property" have not been well received. See Monaghan. supro note 283, al 423-34. 439-14

313. See McKesson Corp. v. Department of Alcoholic Beverages \& Tobacco. 496 U.S 18. 22 (1990) If a state deprives a person of property or liberty without due process. but the depnvation tums out to have 
refund, ${ }^{314}$ a prototypically retrospective remedy for Eleventh Amendment purposes. Because of the Eleventh Amendment, an action for a refund may not be maintained against the states in the lower federal courts, but the state must make the remedy available in its own courts. It may not rely on its law of sovereign immunity to bar the remedy, ${ }^{315}$ and, if it fails to provide the required remedy, the Supreme Court may exercise its appellate jurisdiction and reverse. ${ }^{316}$ The Court appeared to consider its holding an uncontroversial application of principles it had articulated in procedural due process cases such as Mathews v. Eldridge, ${ }^{317}$ in which the Court had held that, while the Due Process Clause does not always require a predeprivation hearing to challenge state deprivations of liberty or property, it does require an effective opportunity to challenge the state's decision at some point. ${ }^{318}$ The McKesson Court stressed that the hearing must come "at a meaningful time," which it interpreted to mean that the hearing must at least come before the deprivation becomes final. ${ }^{319}$ The Court appears to have concluded that a deprivation of property is not final if an opportunity to obtain a postdeprivation remedy exists. It accordingly held that the Due Process Clause requires that a deprivation of liberty or property by the state be accompanied by an opportunity to obtain a retrospective remedy from the state if no predeprivation opportunity to test the deprivation's conformity with law was available and if no other remedy would cure the violation of law.

Our discussion of the abrogation reductio in Section A of this Part allows us to appreciate the depth of McKesson's conflict with the immunity-fromliability interpretation. Under that interpretation, Congress lacks the power to subject states to damage liability under its Article I powers. But as we saw, Congress has the power under Article I to create "property" rights for purposes of the Due Process Clause simply by placing mandatory obligations on the states. ${ }^{320}$ Under McKesson, Congress's creation of a property right against the states automatically gives rise to an obligation on the state's part to pay damages to the property holder if the state has deprived that person of her property without affording a predeprivation hearing (and no other remedy would cure the violation). Thus, under McKesson, not only is the state not

\footnotetext{
been consistent with substantive law, the person is nevertheless entitled to compensation under section 1983 for injuries suffered as a result of a violation of procedural rights. See Carey v. Piphus, 435 U.S. 247 , 254-57 (1978). McKesson is understood to stand for the proposition that if the deprivation turns out to have been in violation of substantive law, the person is also entitled under the Due Process Clause to a remedy sufficient to cure the violation.

314. But cf. supra note 123 (noting that if tax is unconstitutional because discriminatory, refund may not be required).

315. See Reich v. Collins, 115 S. Ct. 547, 549 (1994).

316. See McKesson, 496 U.S. at 27.

317. 424 U.S. 319 (1976).

318. See id. at 348-49.

319. See McKesson, 496 U.S. at 38-39.

320. See supra note 287 and accompanying text.
} 
immune from congressional power to subject it to damage liability, the state is constitutionally obligated to pay individuals damages whenever it has violated a mandatory obligation imposed on it by Congress vis-à-vis individuals, even if Congress did not expressly create a damage remedy. McKesson, so interpreted, is thus fundamentally incompatible with the immunity-from-liability interpretation.

If so, then McKesson seems to entrench the abrogation reductio. This would indeed be the case if the immunity-from-liability interpretation were correct. As discussed above, under the immunity-from-liability view, Congress would have the power to abrogate that immunity whenever it has the power to legislate substantively. McKesson tells us that Congress would be "abrogating" this immunity by legislating substantively. There would be no need for an additional act of "abrogation" to render the states liable in damages. Thus, if we assumed the correctness of the immunity-from-liability view, McKesson would make the abrogation reductio more of a problem, not less.

If the forum-allocation interpretation were correct, however, McKesson and related procedural due process cases would offer a rationale for avoiding the abrogation reductio. By hypothesis, Congress would have the power to subject the states to damage liability to individuals; Eleventh Amendment immunity would simply be an immunity from the original jurisdiction of the federal courts. Suppose Congress has made states liable in damages to individuals for patent infringement. As we saw, the individual would then have a property interest in receiving damages from the state. ${ }^{321}$ Under McKesson, the state violates the Due Process Clause if it does not pay the individual the damages. But, by the same token, the state would satisfy its obligations under the Due Process Clause (with respect to the patent holder's property interest in damages) ${ }^{322}$ by making available a damage remedy in its own courts. If a state enacted a law giving individuals a right to obtain damages for patent infringement against the state in state courts, then Congress would be hard pressed to justify an abrogation of Eleventh Amendment immunity (meaning here immunity from lower federal court jurisdiction) under the Fourteenth Amendment's Due Process Clause. If the state did not subject itself to damage liability in its own courts, then Congress would be justified in abrogating the immunity (thus making the state suable for damages in federal court). But the abrogation reductio would be avoided because Congress's power to abrogate would not be coextensive with its power to legislate; it would depend as well on the state's failure to open its courts up to patent claims against itself and

321. See supra text accompanying note 284 .

322. The discussion in this paragraph assumes that the only relevant property nght is the nght to damages. Below, I consider the analytical modifications required by the recognition that there is also a property right in noninfringement. 
its agencies. Notice that the price the state must pay to avoid Congress's power to subject it to federal jurisdiction would be its agreement to waive its immunity from the jurisdiction of its own courts. The resulting scheme would be precisely the one that would be produced by the Eleventh Amendment if interpreted as a forum-allocation principle. Defenders of this interpretation regard the Amendment as a sort of abstention doctrine, ${ }^{323}$ a doctrine that entrusts the enforcement of the states' federal liabilities to individuals to state courts that have indicated some willingness to enforce those liabilities faithfully, but reserves a congressional power to confer jurisdiction on the federal courts if the state courts seem unwilling. The proposed rationale for avoiding the reductio, based in part on McKesson, thus seems neatly to "prove" the correctness of the forum-allocation view. Indeed, the resulting scheme would closely resemble the scheme that would have been set up by the proposed substitute for the Eleventh Amendment that was rejected by the Framers immediately before the current version was passed: Congress would lack the power to create a federal forum for the vindication of federal rights only if the states make provision for enforcing those rights in the state courts. ${ }^{324}$

But escaping the reductio is not so easy. Recall that the right to damages is not the only property right involved in patent cases. The patent holder also has a property right in the state's "noninfringement" of the patent. ${ }^{325}$ Does a state satisfy its due process obligations with respect to this property right merely by enacting a law permitting patent holders to obtain damages in state court against the state? Answering this question requires a closer look at the Court's procedural due process jurisprudence, a quagmire into which I venture with some trepidation.

As noted, the Court treated McKesson as merely an application of the Mathews v. Eldridge approach to procedural due process. The Court in Mathews held that the Due Process Clause does not always require a predeprivation hearing; sometimes a postdeprivation hearing will suffice. ${ }^{326}$

323. See Jackson, supra note 1, at 7; see also id. at 99 n.394 (stating that under analysis proposed by author, "whether monetary relief is available in federal district court against states may come to depend, in par, on the adequacy of the remedies available in the state courts"). Because Jackson espouses not only the fonm-allocation view, but also the diversity view (under which Eleventh Amendment immunity could freely be withdrawn by Congress under any of its powers), a decision by Congress that the state courts are inadequate would be binding on the courts. Under the version of the forum-allocation view described here, on the other hand, Congress would have the power to remove cases from the state to the federal courts only if the states fail to set up procedures that comply with the requirements of the Due Process Clause, as interpreted by the courts.

324. See supra text accompanying notes $199-200$. It is not clear that under this proposal the Supreme Court would have retained jurisdiction to review state cour decisions denying the federal right. Perhaps that rejected version of the Eleventh Amendment would have been interpreted to permit the Supreme Count to determine in each case whether, in retrospect, adequate provision had been made for the enforcement in state court of the federal right at issue in the case.

325. See supra note 287 and accompanying text.

326. See Mathews v. Eldridge, 424 U.S. 319, 348-49 (1976). 
McKesson tells us that when a postdeprivation hearing suffices, the Due Process Clause requires the state to make available a damage remedy against itself sufficient to compensate the property holder for losses suffered as a consequence of the legal violation. Now we must consider the cases that tell us when a postdeprivation hearing suffices. The most pertinent line of cases is the one that begins with Parratt v. Taylor ${ }^{327}$ and culminates in Zinermon v. Burch. ${ }^{328}$ These cases are, like McKesson, simply applications of the general principles set forth in Mathews. ${ }^{329}$ They establish that where a person has been deprived of liberty or property ${ }^{330}$ by the state, but a postdeprivation remedy would satisfy due process, the propeny holder may not maintain a damage action against the responsible state officials under section 1983 if state law makes available an adequate postdeprivation remedy. ${ }^{331}$ More important for present purposes, however, is what these cases tell us about when a postdeprivation remedy suffices for due process purposes. Parratt and its progeny establish that postdeprivation remedies suffice when state officials deprive persons of property in a "random and unauthorized" way."332 Parratt's specific holding that a negligent destruction of property is random and unauthorized for this purpose is no longer relevant, as the Coun subsequently held that negligent conduct does not amount to a "deprivation" for due process purposes. ${ }^{333}$ But the more general principle that "random and unauthorized" injury to property does not violate the Due Process Clause if the state makes available a postdeprivation remedy survives. The combination of Parratt and McKesson appears to mean that if a state infringes a patent in a random and unauthorized way, it satisfies its obligations under the Due Process Clause as long as it makes available a postdeprivation damage action against itself in its own courts. But the state violates the Due Process Clause without regard to the existence of a postdeprivation remedy if the infringement was not

327. 451 U.S. 527 (1981).

328. 494 U.S. 113 (1990).

329. See Parratt, 451 U.S. at 540-41 \& n.5; Znemon, 494 U.S. at 127.

330. This analysis would apply only to propeny rights defined by state law. If a person has suffered the deprivation of a property right defined by federal law, then he or she would be able to sue the relevant state official immediately in federal court under section 1983 as defined in Maine $v$. Thiboufor, $\$ 48$ U.S. 1 (1980). (Subsequent cases, including Seminole Tribe itself. may require qualification of this statement at the margins.)

331. See Zinermon, 494 U.S. at 128. This rule is curious in that the availability of a federal forum turns on the absence of positive state law recognizing an obligation that the Due Process Clause durectly imposes on the states. If the Due Process Clause requires a postdeprivation remedy. then state courts are required to make one available, even if the state's written law (be it statuton or judge-made) does not so recognize. The Court accordingly might have said that someone who suffers a depnvatuon of property in circumstances where a postderivation remedy suffices must pursue the postdepnvation remedy in state courts, which under Testa v. Katt, 330 U.S. 386 (1947). are required to provide the remedy. Instead, the Court held that because of the absence of state positive law recognizing the due process obligation to provide a postdeprivation remedy, the property holder gets immediate access to a federal forum in which to seek the postdeprivation remedy. Access to the federal court thus depends on the states' failure to enact what would otherwise be a redundant law.

332. See Zinermon, 494 U.S. at 138-39.

333. See Daniels v. Williams, 474 U.S. 327. 330-31 (1986). 
"random and unauthorized."

The meaning of this term was elaborated in Zinermon. The resulting standard is far from transparent, but it seems fair to say that a deprivation of property would not be random and unauthorized under Zinermon if the possibility that a deprivation would occur was predictable, and if the likelihood of the deprivation occurring could feasibly have been reduced if the state had set up more or better procedures to be followed by the relevant state officials. ${ }^{34}$ In such circumstances, the state is obligated by the Due Process Clause to set up those procedures, ${ }^{335}$ and if it does not, then any deprivation that occurs is a violation of due process without regard to the existence of postdeprivation remedies. This standard is certainly rather fuzzy around the edges, but, as applied to our patent hypothetical, it seems to lead to the conclusion that the state is required under the Due Process Clause not only to make it clear that its officials may not infringe patents, but also to set up some sort of preclearance procedure to be used by any state official who is likely to be using patented technology. Such procedures might have to include notice to potentially interested patent holders and an opportunity to adjudicate such issues as patent validity. If such procedures were "feasible" under Zinermon and the state did not establish them, then any infringement that occurs violates the Due Process Clause. If the state does set up such procedures and an infringement occurs because a state official did not comply with them, then the deprivation was "random and unauthorized." 336 In such circumstances, the state satisfies its due process obligations by making available a postdeprivation hearing, which, under McKesson, must include a right to damages against the state. If the state sets up the required predeprivation procedures and an infringement occurs even though the procedures were followed, apparently the

334. See Zinermon, 494 U.S. at 137-38; see also id. at 139 (commenting that Parratt is a "special instance of the Mathews due process analysis where postdeprivation process is all that is due because no predeprivation safeguards would be of use in preventing the kind of deprivation alleged"); Cleveland Bd. of Educ. v. Loudermill, 470 U.S. 532, 542 (1985) ("“[T]he root requirement' of the Due Process Clause" is "'that an individual be given an opportunity for a hearing before he is deprived of any significant property interest.") (quoting Boddie v. Connecticut, 401 U.S. 371, 379 (1971)).

335. There is some ambiguity in the Zinermon opinion about whether the Court was holding that the state of Florida was obliged under the Due Process Clause to provide greater predeprivation procedural safeguards. See Zinermon, 494 U.S. at 117 (noting that plaintiff "disavowed any challenge to the [Florida] statutes themselves"). However, the Court's repeated statements that Parratt represents "a special case of the general Mathews v. Eldridge analysis," 494 U.S. at 128; see also id. at 129 (stating that Parratt "is not an exception to the Mathews balancing test, but rather an application of [it]"), indicate that the Court held that the state of Florida (either its legislature or the executive official to whom the legislature had delegated the authority to confine mentally ill people) was required by the Due Process Clause to provide greater predeprivation procedural safeguards. See Richard H. Fallon, Jr., Some Confusions About Due Process, Judicial Review, and Constitutional Remedies, 93 ColuM. L. REv. 309, 347 n.219 (1993).

336. This is the clear implication of the Court's conclusion in Zinermon that the state official's conduct was authorized and not random because the state had delegated to him "broad . . . uncircumseribed power to effect the deprivation at issue." Zinermon, 494 U.S. at 136. Thus, if the state had circumscribed the power by establishing procedural safeguards but the officer had violated those procedures, the deprivation would have been random and unauthorized for Parratt purposes and postdeprivation remedies would have sufficed to satisfy the Due Process Clause. 
deprivation does not violate due process and the state is not required to provide a postdeprivation hearing or damage remedy. ${ }^{33 i}$ (Apparently, the predeprivation hearing was all the patent holder was entitled to. Of course, if the forum-allocation interpretation were correct, an appeal to the Supreme Court would be possible from an adverse predeprivation decision of an adjudicatory nature, even if the state provided no "judicial" review.) ${ }^{338}$

If the Due Process Clause does indeed require such preclearance procedures, then this line of cases merely adds to what the state must do to avoid susceptibility to federal jurisdiction. If a state sets up the required preclearance procedures and provides further that a damage remedy is available against the state in state coun if the procedures are not followed and a deprivation results, then it will have done all that it was required to do under the Due Process Clause. Congress would therefore be hard pressed to justify the abrogation of such a state's Eleventh Amendment immunity. If abrogation is not possible under those circumstances, then we will have avoided the abrogation reductio, for it would be fully within the state's power to avoid being made suable by private individuals in federal cour (and, as we are assuming the correctness of the forum-allocation interpretation of the Eleventh Amendment, the states are not immune from federal liability). Under the resulting scheme, a state may be subjected to suit in federal cour if it has not established the provisions for pre- and postdeprivation procedures required by the Due Process Clause, but, if it has established those procedures, the property holder's substantive federal entitlement would have to be litigated in the state courts (or administrative agencies), either before or after the deprivation. Once again, we will have escaped the reductio in a way consistent with the forumallocation interpretation. The role of the Eleventh Amendment under such a scheme would be to channel the adjudication of federal claims against states into the state courts, subject to possible review in the Supreme Courr. ${ }^{339}$

\section{The Scope of Congress's Section 5 Enforcement Power}

There is, however, an obstacle to this escape from the abrogation reductio that we have not yet considered. The line of reasoning just described would

337. This assumes that Congress has not made states liable in damages-in other words. that the only "property" interest involved is the right to noninfnngement. If Congress did subject states to damage liability (something it would have the power to do only if the forum-allocation interpretalton uere correct). then, as discussed above, the patent holder would have an additional propeny interest in being pad the damages and the states would have to provide a forum for the recovery of those damages.

338. See Pacific Gas \& Elec. Co. v. Public Util. Comm'n. 475 U.S. 1. 7 (1986) (allowng review of commission determination where Califomia Supreme Cour had denied discreuonary revew); HakT \& WECHSLER, supra note 100 , at 643 \& n.12. If the Due Process Clause does not require the predeprivation hearing to be "adjudicatory" in nature (with notice to the property holder). then presumably at would require the state to make available a postdeprivation hearing of an adjudicatory nature.

339. See supra note 338 and accompanying text. 
succeed at avoiding the reductio only if Congress's Section 5 power to "enforce" the Fourteenth Amendment were limited to providing additional remedies for the states' completed violations of the first four sections of the Fourteenth Amendment, as the Supreme Court has interpreted them. But there is significant support for the proposition that Congress's power under Section 5 is broader than that. This issue is currently before the Supreme Court. ${ }^{340}$ Whether McKesson and Parratt in fact offer an escape from the reductio consistent with the forum-allocation interpretation may in the end depend on the Court's rejection of some of the broader interpretations of Section 5, or, alternatively, on the Court's willingness to carve out some sort of "procedural due process" exception to Section 5. I conclude that this is not a significant obstacle because one or the other is likely.

Existing precedents appear to recognize that Congress's power under Section 5 extends beyond providing additional remedies for completed violations of the other provisions of the Fourteenth Amendment. First, and most controversially, there is some support for the proposition that Section 5 gives Congress some power to interpret the other provisions of the Fourteenth Amendment to impose broader requirements on the states than the Court has found them to impose. ${ }^{341}$ If so, then perhaps Congress has the power to determine that a deprivation of a property right by the state violates due process without regard to the existence of postdeprivation remedies, and whether or not the state had in place predeprivation procedural safeguards. The broad understanding of Section 5 as giving Congress the power to construe the other provisions of the Fourteenth Amendment to provide broader protections than the Court has read those provisions to afford was limited somewhat in Oregon v. Mitchell. ${ }^{342}$ The deciding vote in that case was Justice Black's, and he expressed the view that Congress's independent power under Section 5 to determine what the substantive provisions of the Fourteenth Amendment require should be confined to the area of race discrimination. However, he would have limited Congress's power to that extent only where Congress was legislating in an area exclusively reserved to the states by the Constitution. ${ }^{343}$ In other areas, Congress's "enforcement power need not be tied so closely to the goal of eliminating discrimination on account of race."344 The scope of Black's exception is difficult to pinpoint, since it would seem that whenever Congress exercises a power granted it by Article I, it has not acted in an area "exclusively reserved to the states." One possibility would be to distinguish

340. The Supreme Court will address the issue in reviewing Flores v. City of Boerne, 73 F.3d 1352 (5th Cir.), cert. granted, 117 S. Ct. 293 (1996).

341. See Katzenbach v. Morgan, 384 U.S. $641,648-49$ (1966). See generally STONE, supra note 301, at $253-66$.

342. 400 U.S. 112 (1970).

343. See id. at 130 .

344. Id. 
legislative powers that the Constitution allocates to Congress with some precision and specificity, as to which the Constitution clearly and specifically negates state exclusivity, from the broader and less specific congressional powers. If such a line were drawn, then a Section 5 power to interpret the requirements of the Due Process Clause with respect to property rights created under specific clauses of Article I, such as that relating to patents, would arguably survive Oregon $v$. Mitchell. This would partially avoid the reductio, for there would still be an Article I legislative power under which Congress would lack the power to abrogate, but it is difficult to come up with a federal legislative power that would be "broad and unspecific" for these purposes other than the power to regulate interstate commerce. Adopting this line would thus reduce Seminole Tribe to a holding that Congress may not abrogate under the Commerce Clause. More importantly, this line seems inconsistent with the specific holding in Seminole Tribe itself, for Congress there had exercised its power over Indian commerce, a subject that has never been exclusively regulated by the states. ${ }^{345}$

Avoiding the reductio may require an adjustment (or clarification) of Section 5 doctrine in other respects as well. First, there is authority for the proposition that where the existence of a violation of the self-executing portions of the Fourteenth Amendment turns on matters of fact, the courts will defer to Congress's reasonable assessment of those facts. ${ }^{3+6}$ If so, then perhaps the Court would defer to a congressional finding that certain property rights against the states would not be adequately protected by the state courts even with Supreme Court review. ${ }^{347}$ Second, even the Justices most eager to

345. See County of Oneida v. Oneida Indian Nation. 470 U.S. 226. 234 (1985).

346. See generally Katzenbach, 384 U.S. 641; Archibald Cox. The Supreme Court. 1965 Term-Foreword: Constitutional Adjudication and the Promotion of Human Rights, 80 HARV. L. REV. 91. 106-07 (1966). Even the petitioners in the Ciny of Boerne case, currently before the Supreme Court, read the Court's past Section 5 cases to uphold Congress's "exercise of supenor factinding shills in the context of applying the Court's designated standard for consututional violations." and they do not ask the Cour to reject those holdings. Brief for Petitioner at 35, Ciry of Boeme (No. 95-2074).

347. Of course, if the form-allocation interpretation of the Eleventh Amendment were correct, then the Amendment might be said to reflect a constitutional judgment that state courts are as good as federal courts in protecting these rights, and a contrary congressional judgment might accordingly be out of bounds. On the other hand, if Congress has the power to abrogate Eleventh Amendment immunity, then presumably it has the power to conclude otherwise. Perhaps the Coun would say that Congress is free to deternine that state courts are not adequate in protecting rights conferred by the substantive provistons of the Fourteenth Amendment, but not rights conferred under Article I. This would come close to a stupulation that the abrogation power simply does not extend to "procedural due process" rights. As discussed below, such a stipulation may, in the end, be the only way to avoid the reductio. See infre note 355 and accompanying text.

There is another, related objection to the congressional "factinding" described in the text. If a state has done everything the Due Process Clause requires it to do. then it seems that Congress is not responding to the states' failure to enforce adequately the Due Process Clause, but rather the states' failure to enforce adequately the laws Congress enacted under Article I. In other words. if a state has set up the procedures the Due Process Clause requires and Congress is still not satisfied. then Congress is saying, essentually, that protecting the "property" right it created requires better procedures than what the Due Process Clause requires. In these circumstances, Congress's objections have nothing to do with the Fourteenth Amendment and everything to do with the laws Congress enacted under Article I. If so. then it seems difficult to justify 
read Section 5 narrowly appear willing to accept that Congress has the power to create remedies where a violation of the Fourteenth Amendment (as the Court would interpret it) "lurks." ${ }^{348}$ In other words, "Congress has the power to forestall the occurrence of acts that would violate rights that the courts have found or would find protected by the [Fourteenth Amendment]."349 While Parratt may establish that there is no completed violation of the Due Process Clause if the state sets up adequate predeprivation procedures and makes available adequate postdeprivation remedies, perhaps the state's infringement of a patent would be regarded as evidence of a "budding," "sprouting," "incipient," or "nascent" violation of the Due Process Clause ${ }^{350}$ that would justify a congressional decision under Section 5 to subject the state to suit in federal court for damages on the theory that state court procedures are unlikely to be effective enough at remedying such infringements. ${ }^{351}$

In the end, though, Section 5 doctrine does not pose a very significant obstacle to the proffered Parratt-and McKesson-based rationales for escaping the abrogation reductio. The arguments for upholding an abrogation on "factfinding" or "prophylaxis" grounds seem question-begging or weak. ${ }^{332}$ The case for a congressional power to abrogate based on a substantive congressional power to interpret the requirements of the Due Process Clause more broadly than the Court does seems stronger, ${ }^{353}$ but this broader

the abrogation as necessary to "enforce" the Due Process Clause.

348. EEOC v. Wyoming, 460 U.S. 226, 260 (1983) (Burger, C.J., dissenting).

349. STONE, supra note 301, at 259. The petitioners in City of Boeme also appear to accept this "prophylactic" use of Congress's Section 5 power. See Brief for Petitioner at 33, City of Boerne (No. 95. 2074).

350. The Fifth Circuit used these adjectives to describe the types of uncompleted violations of the Fourteenth Amendment that would justify congressional exercises of Section 5 power. See Flores v. City of Boerne, 73 F.3d 1352, 1359, 1360, 1361 (5th Cir.), cert. granted, 117 S. Ct. 293 (1996).

351. This argument raises some of the same problems as the "factfinding" argument discussed above. See supra note 347 . It also is in tension with my conclusion above (albeit a tentative one) that a patent infringement by the state would not in fact violate the Due Process Clause if the state provided predeprivation procedures and postdeprivation remedies in the event those procedures were violated. See supra text accompanying note 337.

352. See supra notes 347,351 . Henry Monaghan has argued that, under the reasoning of the Parratt line of cases, Congress would lack the power to provide a federal forum for state deprivations of liberty or property that do not rise to the level of a substantive due process violation. See Henry Paul Monaghan, State Law Wrongs, State Law Remedies, and the Fourteenth Amendment, 86 CoLUM. L. REV. 979, 997-98 (1986). He offers this conclusion as a reason for abandoning Parratt, a decision that he regards as "most puzzling" and inconsistent with "long-embedded understandings of when a denial of due process occurs for fourteenth amendment purposes." Id. at 979. Of course, if the Parratt line of cases is incoherent, then relying on it to avoid the abrogation reductio is problematic, for extending the Parratt analysis to new fields only aggravates the conflict with the "long-embedded understandings" to which Monaghan refers. $I$ do not offer this as a reason for rejecting this possible escape from the reductio, however, because (1) the Cour has not taken up Monaghan's call for Parratt's abandonment; and (2) Parratt and McKesson are closely related offshoots of Mathews, and accordingly rejecting Parratt would come close to rejecting McKesson, something this Section of the Article strives to avoid. Since this effort is not entirely successful for other reasons, I will offer a reinterpretation of McKesson below.

353. This argument still leaves one wondering why Congress should have the power to open up the federal courts to suits against the states even if states are willing to take the additional procedural steps that Congress thinks the Due Process Clause requires. Arguably, Congress's power to abrogate under the Due Process Clause should always be contingent on the states' unwillingness to provide procedures the Due 
interpretation of Section 5 may not long survive. Even if it does, the Court could in the end avoid the abrogation reductio by stipulation: It could simply hold that whatever the scope of Congress's power to abrogate under Section 5 to "enforce" the "substantive" provisions of the Fourteenth Amendment, that power does not extend to "procedural" provisions such as the procedural Due Process Clause. Such an "exception" would not be entirely without theoretical grounding ${ }^{354}$ or support in the case law. ${ }^{355}$ It may, in the end, be the only way to avoid the abrogation reductio.

\section{The Untenability of the Conventional Reading of McKesson}

Although this analysis of McKesson and related due process cases may help avoid the reductio while preserving the forum-allocation interpretation of the Eleventh Amendment, our analysis has at the same time exposed the implausibility of the conventional understanding of McKesson's due process holding. When we began this discussion we were concerned that the Due Process Clause gave Congress too much power: that it gave Congress the power to abrogate Eleventh Amendment immunity under Article I, whereas the Seminole Tribe decision denied Congress that power. Now it has become clear that McKesson as conventionally understood is implausible because it would unduly limit Congress's powers.

As explained above, the procedural due process cases, including McKesson, actually deny Congress the flexibility to choose how to give efficacy to the obligations it places on the states. ${ }^{356}$ Even though Congress chose to rely on postdeprivation damage actions as the principal means of giving efficacy to the patent laws, Zinermon would apparently require the states to set up some sort of preclearance procedure. Because such procedures would be required by the Constitution, presumably a state that has not set them up could be ordered to do so by a federal coun. ${ }^{357}$ Perhaps this result accords with the Eleventh Amendment's preference for prospective relief over

Process Clause requires, whether those requirements are determined by the Count or by Congress if so. then any valid exercise of the abrogation power premised on the Due Process Clause must always be phrased in conditional form-for example. "Federal couns shall have jurisdicuion over suis to eniorce [property right $X$ ] against states that do not enact [procedure $Y$ ] to protect such nght "

354. See supra note 337 .

355. The Court has, for example, been willing to distingussh procedural due process claums from outer constitutional claims for purposes of section 1983. On this disunction. see Monaghan, supro note 352.

356. See supra Subsection IV.C.1.

357. Assuming, of course, someone with standing socks such relief. If the states had the chotec between setting up such procedures and submitung to the junsdiction of the federal courts, then this interpretation of Zinermon might actually help advance Congress's goal of having patent clums lugated in the federal courts, for states may well prefer to submit to federal court suits aganst themselves than to incur the cost of setting up the procedures Zinermon would appear to require. But. If the Dute Process Clause requires the predeprivation procedures, the states presumably do not have the option of dechning to set them up. 
retrospective relief. (Although the states remain liable in damages if infringements occur, presumably fewer infringements will occur if the state offers a hearing before the deprivation.) But it does seem odd, to say the least, to interpret the Due Process Clause in such a way as to require the conclusion that a federal statute that can be constitutionally applied to the states only because it also applies to private individuals ${ }^{358}$ places substantial burdens on states that Congress has not opted to place on anyone. That no one has ever suggested that states are required to set up preclearance procedures to avoid patent violations casts doubt on the conclusion that the Due Process Clause requires this strange result.

More important for our purposes, McKesson appears to require a damage remedy from the state for every violation of mandatory obligations imposed on the state by federal statute for the benefit of individuals, even if Congress has chosen not to provide a damage remedy. ${ }^{359}$ McKesson thus denies Congress the power to place mandatory obligations on states for the benefit of individuals but to rely for their enforcement exclusively on mechanisms other than private damage actions. ${ }^{360}$ There is an argument to be made that individuals who have been given "rights" against the states by federal statutes that impose obligations on states for their benefit should always be entitled to a damage remedy if the state violates that obligation and causes them injury. ${ }^{361}$ But the claim that our Constitution establishes such a regime is inconsistent with too many Supreme Court decisions to be plausible. For this reason, an interpretation of McKesson that would require that conclusion is implausible too.

As Justice Brennan, McKesson's author, wrote in Davis v. Passman, ${ }^{362}$ "statutory rights and obligations are established by Congress, and it is entirely appropriate for Congress, in creating these right and obligations, to determine in addition who may enforce them and in what manner." ${ }^{363}$ Other cases make

358. See supra text accompanying note 99.

359. If Congress has not expressly created a damage remedy, the Zinermon/McKesson anaiysis leads to the conclusion that the Due Process Clause requires a damage remedy if: (1) the state has not set up the required predeprivation procedures and a wrongful deprivation occurs; and (2) if the state has set up such procedures and a wrongful deprivation occurs because the procedures were not followed.

360. It would remain open to Congress to phrase the statute in such a way as to make the state's conduct nonmandatory. See, e.g., Pennhurst State Sch. \& Hosp. v. Halderman, 451 U.S. 1, 18-25 (1981). But presumably, if the state's obligation were not mandatory, no one would have the power to obtain prospective relief. McKesson, as construed above, would appear to require a private damage remedy under the Due Process Clause whenever the state has violated a federally imposed obligation if the obligation is mandatory in the sense that prospective enforcement would be appropriate, and the obligation is towards individuals such that the individual could be said to have a correlative "property" right. On this latter requirement, see supra note 288.

361. See supra note 21.

362. 442 U.S. 228 (1979).

363. Id. at 241. It might be objected that Justice Brennan's statement is inapposite because he was speaking about statutory rights imposing obligations on private individuals, not states. (Violation of statutory obligations by private individuals does not, of course, produce violations of the Due Process Clause.) However, Brennan does not confine his statement to statutes that impose obligations on private 
it clear that one of the choices Congress might make when imposing an obligation on a state would be to permit individuals to maintain an action for prospective relief only. That Congress made such a choice appears to have been the Court's assumption, for example, in the Edelman case, ${ }^{360}$ where there was no question that the claimants had "property" interests against the state. ${ }^{365}$ The Will case not only denied a damage remedy against the state under section 1983, but established a strong presumption that no such remedy exists unless Congress clearly says otherwise. ${ }^{366}$ Likewise, the Sea Clammers line of section 1983 cases clearly recognized that Congress may impose obligations on states yet preclude damage claims against the state or its officials. ${ }^{367}$ The reasoning of the Sea Clammers line of cases was endorsed and indeed extended to a new context in Seminole Tribe itself. ${ }^{368}$ If so, then

individuals, and the Davis case itself involved a claim aganst a government officul.

364. This is the interpretation that is most congenial to the form-allocatuon view. Cf supra note 273

365. The benefits were not distinguishable in this respect from those involvod in Goldberg * Kells. 397 U.S. 254 (1970), or Mathew's v. Eldridge. 424 U.S. 319 (1976) See supra note 311

366. See supra Subsection III.C.4. Section 1983 entules individuals to a remedy only if federal law gives them a "right[], privilege[], or immunit[y]." 42 U.S.C. $\$ 1983$ (1994). The Coun in Penn/urst had already interpreted this requirement as not authorizing relief if the relevant federal law did not unpose mandatory obligations on the states. See Pennhurst State Sch \& Hosp. V Hilderman. 451 L'S 1. $27-28$ (1981). And in Golden State Transit Corp. v: Cin of Los Angeles. 493 L.S 103 (1989), the Coun wrote that the availability of a remedy under section 1983 to enforce a foderal stutute 7ums on whether the statute, by its terms or as interpreted, creates obligations 'suffictently specific and definte' to be wathe 'the competence of the judiciary to enforce," is intended to benefit the putauve plainuff. and is not foreclosed "by express provision or other specific evidence from the statute itself.". Id. at 108 (quoung Wnght $v$ Roanoke Redevelopment \& Hous. Auth., 479 U.S. 418.423 (1987)). The first two requirements suggest that anyone who would have standing to enforce a statute under section 1983 would have a property nght in the state's compliance with the statutory obligation See supra note 287 and accompanying text (discussing definition of "propeny" for purposes of Due Process Clause) Thus. Will's denal of a damage remedy against states was relevant only where persons would othenwise apparently have possessed a property right vis-à-vis the states under federal law. See Will v. Michigan Department of Stale Police, 491 U.S. 581 (1989). The third Golden State requirement, see 493 U.S. at 108, ts, of course, a recognutson that Congress may "foreclose" private damage actions for persons who would aherwise possess a "property" right, something that is inconsistent with McKesson's holdung that the Due Process Clause requires such damages, see McKesson Corp. v. Department of Alcohohc Beverages \& Tobacco. 496 U S 18, 22 (1990)

367. See Middlesex County Sewerage Auth. $\vee$. National Sea Clammers Ass' $n$. 453 U.S I (1981) Sec generally HART \& WECHSLER, supra note 100, at 1134-36 (discussing Sea Clanvners and subsequent decisions). This case and its successors hold that where Congress has imposed an oblugauon on stales by statute but has established an exclusive enforcement scheme, the section 1983 remedy is unavailable This is so even if the exclusive enforcement scheme does not make a damage remedy available. See td al 11 is The Cour in these cases held that a damage remedy was unavailable under secuon 1983. It did not considet whether the Due Process Clause independently required a damage remedy. but its whole analysis is inconsistent with such a conclusion. The Sea Clammers line of cases denies the exustence of a damage remedy against state officers. See id. The IVill case establishes that a damage remedy against the state tuself is unavailable in these cases. See supra note 366.

368. The Seminole Tribe Count relied on the reasoning of Sea Clammers in denying the Tnbe's nghi to maintain an Ex parte Young action aganst the Governor of Flonda. See Semunole Tribe Y Flonda, 116 S. C. 1114, 1132-33 (1996). Although the Coun inexphcably did not cile Sea Clanuners. It reasoned in a strikingly similar manner. The Court found the Ex pare Young remedy unavailable because Congress had established a liability scheme that, in the Cour's view, was incompatible with the existence of such a remedy. I agree with the criticisms raised by scholars about the Court's application of thus pnncuple in the Seminole Tribe case itself. See generally Jackson, supra note 15. However. I do not find the prunciple that an Ex parte Young remedy should not be available to enforce a statutory nght where Congress has established an altemative enforcement scheme that is incompatible with such remedy any more objectionable than the decision in Sea Clammers. 
McKesson is in conflict with Seminole Tribe in yet another way. Given the many decisions affirming Congress's power to impose mandatory obligations on states without subjecting them or their officials to damage liability, ${ }^{369}$ an interpretation of McKesson that would disable Congress from doing so must be wrong.

\section{REINTERPRETING MCKESSON}

In this Part, I shall suggest two possible ways to reinterpret McKesson without abandoning its key holding that a retrospective remedy was required in that case. The first reinterpretation responds directly to the problem just discussed: that McKesson's due process holding, as conventionally understood, would deny Congress the power to place mandatory obligations on states without subjecting them to damage liability. This first reinterpretation retains the holding that Florida was required to provide a retrospective remedy against itself in its own courts, but regards the source of that obligation not to be the Due Process Clause, but the substantive provision of federal law that Florida violated, the dormant Commerce Clause. This first reinterpretation has the virtue of squaring McKesson with the cases recognizing that Congress may impose obligations on states without subjecting them to damage liability. But there are problems with this interpretation, the principal one being that the decision offers no basis for distinguishing the dormant Commerce Clause from any other constitutional or statutory provision. Indeed, the Court's reliance on the Due Process Clause indicates that it regarded the remedial principle it articulated as a generally applicable one.

My second proposed reinterpretation helps address this problem. This reinterpretation reads McKesson to establish a generally applicable right to damages for the violation by the states of federal laws, but it reads the case to establish a right to damages from responsible state officials rather than the governments for which they work. Even if not combined with the first reinterpretation-that is, even if the right to damages were regarded as having

Like the Sea Clammers decision itself, this aspect of Seminole Tribe appears to be in conflict with the McKesson/Parratt/Zinermon cases as well as another line of procedural due process cases, the Amet//Loudermill line discussed below. See infra text accompanying notes 375-81. If McKesson stands for the proposition that a state must provide a postdeprivation hearing and a damage remedy if the deprivation turns out to have been invalid, it must also require the availability of injunctive relief if the deprivation is a continuing one. If so, it is in tension with the Court's holding in Seminole Tribe that no such relief was available even in a suit against the Governor. But cf. Seminole Tribe v. Florida, 11 F.3d 1016, 1025 (11th Cir. 1994) (holding that IGRA gave Tribes no property interest). This may be yet another fundamental conflict betwcen MCKesson (as conventionally understood) and Seminole Tribe.

369. In addition to the other decisions cited in this Subsection, see Martinez v. California, 444 U.S. 277,282 (1980) (assuming that individuals have property interest in state wrongful death actions and that state law of sovereign immunity "deprives" people of such property insofar as it immunizes statc officials from wrongful death liability, but finding nevertheless that immunity is constitutional because "the State's interest in fashioning its own rules of tort law is paramount to any discernible federal interest"). 
its source in the Due Process Clause-the second reinterpretation would have the virtue of reconciling McKesson with doctrine in related areas. But this interpretation would not avoid the problems with McKesson just identified. To do the latter, we must combine the two reinterpretations of McKesson.

But, if the source of the obligation to award damages is not the Due Process Clause, how can it nevertheless be a generally applicable one? The answer is suggested by the close affinity that becomes apparent, when we construe McKesson as an officer liability case, between McKesson and such other officer liability cases as Ex parte Young, Bivens, ${ }^{370}$ and Poindexter. All of these cases, I maintain, are best understood as establishing that the Constitution itself requires effective remedies, both prospective and retrospective, whenever the Constitution is violated, but that the remedies the Constitution contemplates are remedies against officials rather than the governments for which they work. I locate this constitutional principle in the Supremacy Clause. Unlike the Due Process Clause, the Supremacy Clause is flexible enough to accommodate an exception for statutory claims where Congress in enacting the statute provided for alternative remedies or precluded private remedies altogether.

\section{A. Reinterpreting McKesson as to the Source of the Obligation to Afford Relief}

As just noted, an interpretation of McKesson that would read it to disable Congress from placing obligations on states without subjecting them to private damage liability cannot be right. The most straightforward way to avoid this problem without calling into question the Cour's holding that the state was required to pay damages to the plaintiff would be to reject what the opinion suggests about the source of the state's obligation to pay damages. As discussed, the McKesson Court relied on the Due Process Clause, and the case is naturally understood to stand for the proposition that the source of the state's obligation to pay damages is the Due Process Clause. ${ }^{37}$ An alternative interpretation that would avoid this problem would regard the state's obligation to pay damages as having its source not in the Due Process Clause, but in whatever law imposed the obligation that was violated. The claim in McKesson was that the state tax was invalid because it discriminated against interstate commerce and thus violated the dormant feature of the Commerce Clause. The proposed alternative interpretation of McKesson would read the

370. Bivens v. Six Unknown Named Agents, 403 U.S. 388 (1971) (recognizing federal nght of action for damages against federal officials who violate Fourth Amendment).

371. See, e.g., HART \& WECHSLER, supra note 100. at 852 (commenuing that IIeKesson Court treated remedial obligation as arising not from constitutional provision that was volated (domant Commerce Clause) but from Due Process Clause). 
case as establishing that the damage remedy that Florida was under an obligation to provide was required by the Commerce Clause itself, not the Due Process Clause. On this reading, a state is obligated to provide a damage remedy for violation of a federal norm if the federal norm that imposes the obligation on the state (or some other federal norm) makes the state liable in damages. ${ }^{372}$ The Due Process Clause would not be the source of the right to damages. Arguably, the Due Process Clause would require the state to make available a forum in which to seek a damage remedy made available by some other law if some other law makes a damage remedy available, ${ }^{373}$ but the more appropriate source of this obligation would in my view be the Supremacy Clause, which by its terms requires state courts to give effect to federal law. ${ }^{374}$

There are, however, problems with this alternative interpretation of McKesson. First, the proposed interpretation of the Due Process Clause as not requiring any greater remedies than what the substantive law makes available comes close to adopting the view of that Clause that was forcefully espoused by Chief Justice Rehnquist in Arnett v. Kennedy ${ }^{375}$ but has been decisively rejected by the Court. Rehnquist's well-known "bitter with the sweet" approach to statutorily created property interests insists that if the legislature establishes a mandatory state obligation but at the same time establishes a streamlined procedure for enforcing the obligation or correcting violations, then the procedural limitations necessarily qualify the "property" right at issue. ${ }^{376}$ In such circumstances, the process that is due is only the process the legislature provided for in the statute. ${ }^{377}$ Whatever the theoretical appeal of Rehnquist's reasoning, a majority of the Court rejected it in Arnett, ${ }^{378}$ and again in Cleveland Board of Education v. Loudermill: ${ }^{379}$

372. I do not mean, by phrasing the rule in this way, to suggest that there should be a presumption that damages are not available unless specifically authorized. Rather, I mean merely that the availability of damages should be a matter of interpreting the legal provision that imposes the obligation, or conceivably another legal provision, such as section 1983, intended to establish supplementary remedics. The presumptions that should apply in this interpretive enterprise are another question entirely. In another piece, I argue that the Supremacy Clause should be read to establish that prospective and retrospective relief are presumptively available for the violation of any federal legal norm. See Vázquez, supra note 80, at 74.

373. The Due Process Clause would perhaps also give the state the option of replacing the damage remedy with an adequate predeprivation opportunity to test the legal obligation. See Ward v. Board of County Comm'rs, 253 U.S. 17 (1920) (recognizing that Due Process Clause would not have bcen violated if plaintiffs' decision to forgo predeprivation procedures had truly been voluntary).

374. See U.S. ConST. art. VI, cl. 6 ("This Constitution . . . shall be the Supreme Law of the Land"); Testa v. Katt, 330 U.S. 386 (1947).

375. 416 U.S. 134 (1974).

376. See id. at $153-55$.

377. See id. at 177-78 (White, J., concurring in part and dissenting in part).

378. See id. at 166 (Powell, J., concurring in par); id. at 177-78 (White, J., concurring in part and dissenting in part); id. at 211 (Marshall, J., dissenting) ("[A] majority of the Coun rejects Mr. Justice Rehnquist's argument.....").

379. 470 U.S. 532 (1985). 
The point is straightforward: the Due Process Clause provides that certain substantive rights-life, liberty, and property-cannot be deprived except pursuant to constitutionally adequate procedures. The categories of substance and procedure are distinct. Were the rule otherwise, the Clause would be reduced to a mere tautology. ... "While the legislature may elect not to confer a property interest . . . . it may not constitutionally authorize the deprivation of such an interest, once conferred, without appropriate procedural safeguards." 380

In short, in determining the scope of a "property" right created by statute, one looks at the substantive obligations the statute imposes, but not to the procedures the statute sets up to enforce those obligations. Once the property right has been defined, the Due Process Clause kicks in and tells us what procedures the state must offer for its enforcement. The legislature presumably has the power to require more or better procedures than what the Due Process Clause would require, but it cannot offer less. This reasoning appears to require the conclusion that the procedures the state must afford to protect property rights created by federal statute, such as the right to be free from patent infringement, are not just those defined by Congress, but also those required by the Due Process Clause.

Admittedly, the tension between my reinterpretation of McKesson and Amett and Loudermill is significant. Yet if we do not reinterpret McKesson, we will be stuck with a substantial conflict between that decision and the cases that indicate that Congress may create a primary obligation but withhold a damage remedy. This shows that the real conflict is not between Amett/Loudermill and our reinterpreted McKesson, but between Armett/Loudermill on the one hand and the cases recognizing congressional discretion to create a substantive obligation but withhold a damage remedy on the other. While Arnett seems to require a separation between the legislature's power to impose primary obligations and its discretion to determine the methods of enforcing it, Sea Clammers and the other cases discussed above appear to say that the availability of remedies for the violation of statutorily created obligations is entirely up to the legislature to determine. This conflict will have to be resolved somehow, and I am confident that it will not be resolved by denying Congress the discretion to withhold a damage remedy. It may be possible to resolve this conflict within the analytical framework established in Loudenmill. Perhaps damage remedies could be conceptualized as "substantive" for due process purposes. ${ }^{361}$ This is not the place to

380. Id. at 541 (quoting Amett, 416 U.S. at 167 (Powell. J., concumng in part)).

381. This would be inconsistent with McKesson's holdıng that the Due Process Clause requires the damage remedy, see McKesson Corp. v. Deparment of Alcoholic Bevernges \& Tobacco. 496 U.S 18. 22 (1990), but this is precisely the aspect of McKesson that our first reinterpretainon rejects. It is true that Parratt and Zinermon seem to hold that a damage remedy is required by the Due Process Clause in certain 
elaborate possible resolutions of this problem beyond noting that Congress's power to establish obligations but withhold a damage remedy is far better established than the due process obligation of a state to pay damages to individuals, and so the former would likely prevail in a head-to-head conflict.

A second problem with this proposed reinterpretation is that the Court's opinion in McKesson makes it quite clear that it is resting the obligation to award a damage remedy on the Due Process Clause. The Court's reliance on the Due Process Clause indicates that the Court was making a general point about the importance of and need for retrospective remedies. The Court says nothing in the opinion to distinguish the remedial imperatives of the dormant Commerce Clause from those of any other constitutional provision, or indeed any other provision of law. In short, the McKesson opinion resists being recharacterized as a decision about the remedies required by the dormant Commerce Clause.

On the other hand, as we have seen, the due process interpretation produces a sharp conflict with cases that have not generally been regarded as constitutionally problematic. Doctrinal coherence demands that this conflict be resolved. Reinterpreting McKesson as a holding about the remedies required by the dormant Commerce Clause resolves the conflict without rejecting the narrow holding that Florida was required to pay damages in that case, and this sort of resolution is preferable to an outright overruling of McKesson. ${ }^{382}$ Nevertheless, a resolution that pays greater regard to the Court's evident intent to make a more general point about remedies would be preferable. On this score, the second reinterpretation I suggest below, when combined with the first, comes out ahead.

\section{B. Reinterpreting McKesson as to the Subject of the Duty to Pay Damages}

A second possible reinterpretation of the McKesson decision would view it as establishing that individuals injured by a state's violation of mandatory federal obligations have a right to damages not from the state itself, but from state officials. I will discuss in Section $C$ how this second proposed reinterpretation helps address some of the problems of the first. The appeal of the second reinterpretation, however, does not depend on acceptance of the

circumstances. Yet as discussed below, these cases do not in fact hold that the damages must come from the state itself. To the extent that these cases hold that the Due Process Clause requires a damage remedy against state officials for violations of duties imposed by statute even if the legislature that created the obligation specifically withheld a damage remedy, these decisions are in conflict with Sea Clammers and might have to be rethought. But I am not alone in calling for a reconsideration of these cases. See, e.g., Fallon, supra note 335; Monaghan, supra note 352; Michael Wells \& Thomas A. Eaton, Substantive Due Process and the Scope of Constitutional Torts, 18 GA. L. REv. 201 (1984).

382. Compare the majority's treatment of precedent in United States v. Lopez, 115 S. Ct. 1624 (1995), in which the Court purported not to disturb the actual results in such prior cases as Wickard v. Filburn, 317 U.S. 111 (1942), even though it clearly (though not explicitly) rejected the tests applicd in those cases. 
first reinterpretation. We would derive some doctrinal benefits from adopting the second proposed reinterpretation of McKesson even if we rejected the first reinterpretation and assumed that the individual's right to damages is grounded in the Due Process Clause. These benefits include greater cohesion between McKesson and the Parratt line of cases, Will and other cases denying damage relief against the states in state court, and, most importantly, Seminole Tribe. Indeed, this second proposed reinterpretation adds internal consistency to the McKesson opinion itself by providing an explanation of the Court's "assent" language. By doing so, however, it withdraws McKesson from the ranks of the cases supporting the forum-allocation interpretation and places it among those supporting the immunity-from-liability interpretation.

The defendant in McKesson was a state agency, which for Eleventh Amendment purposes is treated as the state itself. ${ }^{383}$ It was against the state agency that, under state law, the plaintiff was to bring an action for a refund of the taxes it claimed had been unlawfully exacted. The state courts agreed that the taxes were unlawful, but they denied a refund for a variety of reasons. ${ }^{384}$ The Supreme Court reversed, holding that the reasons cited by the state court could not override the due process requirement of a remedy. The Court held that the Due Process Clause required a remedy against the state itself, ${ }^{385}$ but to the extent that the Court suggested the refund must as a constitutional matter come from the state, the Court's language was dictum. The state itself had designated the state agency as the relevant defendant. With relatively little massaging, the opinion could be read to establish that the Due Process Clause requires a retrospective monetary remedy sufficient to cure the violation of law, but that the remedy as a constitutional matter need be available only from the responsible state official. It can come from a state agency if the state designates such an agency as the proper defendant, but in the absence of such a designation, the Due Process Clause requires only that a damage action be available against the official.

This interpretation of McKesson helps harmonize this decision with Supreme Court precedents in a number of related areas. First, it helps reconcile McKesson with the Parratt line of cases. In all of those cases, after all, the defendant was a state official, not the state itself. The Cour held in these cases that no violation of due process occurs when a state official deprives an individual of property in a random and unauthorized way so long as the state makes available a postdeprivation tort remedy against the official. ${ }^{336}$ It is true

383. See supra note 100.

384. See McKesson, 496 U.S. at 22.

385. See id. at 31; see also HART \& WeChSLER, supra note 100, at 866.

386. Although the postdeprivation remedy in Parratt itself was a remedy agaunst the state, see Parratt v. Taylor, 451 U.S. 527 (1981), in subsequent cases the Cour has found posidepnvauon remedies against the official to satisfy due process. see, e.g., Zinermon v. Burch. 49.4 U.S. 113, 115 (1990) (holding that "postdeprivation tort remedy" suffices under Due Process Clause when conduct causing deprvalton is random and unauthorized; such ton remedies are usually aganst officials rather than government isclf): 
that these cases were brought under section 1983, and the Court has held that section 1983 does not authorize damages suits against the states themselves. ${ }^{387}$ This explains why the defendants in these cases were individuals rather than the state. But, if the Court had believed that the Due Process Clause required a damage remedy against the state itself, it would presumably have found the individual liable for the deprivation of property so long as the state did not make available a damage remedy against itself in state court. Yet the Court has found the availability of damages against officials personally to be sufficient to negate a due process violation.

This interpretation of McKesson also reconciles it with Will. The issue in that case was whether damages could be recovered in state court against the state itself under section 1983, where the state had injured the plaintiff in violation of the Fourteenth Amendment's Equal Protection Clause. ${ }^{388}$ The Court decided that Congress had not clearly manifested an intent to render states liable under section 1983, and thus no damages were available even in state court. The substantive violation in that case was a violation of the Equal Protection Clause, so Congress has the power to abrogate Eleventh Amendment immunity with respect to the claim-if it wishes to do so-even after Seminole Tribe. But, if state deprivations of property or liberty interests without due process render the states themselves liable in damages, then plaintiffs would be constitutionally entitled to maintain such a suit in state court even without relying on section $1983 .^{389}$

Most importantly, the second reinterpretation helps make sense of the McKesson Court's reference to the state's "assent," and thus lends the opinion internal consistency that it would lack under the prevailing interpretation. I earlier dismissed the McKesson Court's reference to the need for the state's "assent" primarily because it conflicted with the Court's due process holding. ${ }^{390}$ If the Due Process Clause's requirement of a remedy flows from

Hudson v. Palmer, 468 U.S. 517, 520 n.1 (1984); see also Fallon, supra note 335, at 349 (suggesting that Parratt requires federal courts "to develop constitutional standards defining the scope of various officials' ... liabilities") (emphasis added) (footnote omitted). See generally infra Section V.C.

387. See Will v. Michigan Dep't of State Police, 491 U.S. 58, 68-69 (1989).

388. See id. at 66 .

389. As noted above, persons who have a "right, privilege, or immunity" for purposes of section 1983 also likely have "property" rights for purposes of the Due Process Clause. See supra note 366.

390. See supra text accompanying note 169. I also relied above on the Court's citation of General Oil Co. v. Crain, 209 U.S. 211 (1908), a case in which the state used its own law of sovercign immunity to deny relief and the Court exercised appellate jurisdiction anyway, ruling that an injunction was required by the Constitution. The defendant in Crain, however, was a state official. Our reinterpretation of McKesson allows us to explain Crain as establishing both that the Constitution requires that an injunction be available for ongoing violations of the Constitution and that a suit seeking an injunction against a state official is not a suit against the state for purposes of the Eleventh Amendment. This is, of course, how I have read Ex parte Young, 209 U.S. 123 (1908). Crain is thus entirely in accord with this Article's thesis. Indeed, the Crain Cour relied heavily on the same cases 1 rely on here, such as Poindexter. See 209 U.S. at 225-27 (citing Poindexter v. Greenhow, 114 U.S. 270 (1885)); see also infra Section V.C (cxplaining Poindexter's bearing on the proposed reinterpretation of McKesson). 
the requirement of a hearing at a meaningful time, then clearly the remedy cannot be dependent on the state's consent to provide the hearing. This must mean, I concluded, that states are not free to deny a hearing on the basis of their own law of sovereign immunity. But, if we reinterpret McKesson as establishing a due process right to a hearing and a remedy against the responsible state official, but not the state, McKesson's assent language begins to make sense. Although the Due Process Clause does not require a remedy payable by the state itself, the state is free to substitute itself as the proper defendant, as it had done in McKesson. If it does so, it is (by hypothesis) voluntarily consenting to suit against itself. The reinterpretation of McKesson's due process holding thus makes it possible to understand McKesson's Eleventh Amendment holding as stating that the state consents to suit by voluntarily substituting itself for the official as the defendant, and that if it does so, the Supreme Court has appellate jurisdiction. If the state does not agree to do so, then the official would remain personally liable, and, if the state court does not enforce that liability, the Supreme Cour can do so through its appellate jurisdiction. Where the state has not agreed to substitute itself as the defendant, the Supreme Court would have no appellate jurisdiction over a suit against the state itself, and the state would not be subject to liability under the Due Process Clause. Because this reinterpretation makes sense of the Cour's "assent" language, it reads the opinion in its best light. ${ }^{391}$ Finally, and perhaps most importantly, the new understanding of both aspects of McKesson helps reconcile the case with the language in Seminole Tribe to the effect that the Supreme Court possesses appellate jurisdiction over cases brought against the states in state courts only where the states consent to the lawsuit.

As noted above, Vicki Jackson, in defending the forum-allocation interpretauon, has asserted thas "[t]he mere existence of the state coun of general jurisdiction to which a claim aganst the state mighı be presented, even absent the state's consent to be sued. has jusufied the Supreme Court's asserion of constitutional obligations to provide remedies against the state." Jackson. supra note 1. at 38 But the cases she cites for this statement are consistent with the suggested reinterpretation of MeKesson All but two are suits against state officials or local governments, which are not regarded as the state for Eleventh Amendment purposes. Of the other two, McCullough b: Virgina. 172 U.S. 102 (1898). appears to be a case in which the state did not invoke sovereign immunty in the state courts. lowa-Des Moines Nanonal Bank v. Bennett, 284 U.S. 239 (1931), is more difficult to square with a requirement of consent to sult in the state courts. The state there defended the case on the ground thal the acts of the state's officials in unconstitutionally collecting a tax were in violation of state statutes and thus not acts atunbutable to the state. See id. at 243-44. The Supreme Coun reversed, and, relying on such cases as Home Telephone \& Telegraph Co. v. Los Angeles, 227 U.S. 278 (1913), held that the unconsututional arts were attributable to the state. See lowa-Des Moines Nar'l Bank. 284 U.S. at 246-47. Whule admuttedly a close question, the case might be reconciled with the requirement of consent on the theory that the stale was not denying consent to suit, but merely denying (erroneously) that there was any state acuon for purposes of the Constitution.

391. This reading is also consistent with all of the cases on which the Coun relied in McKesson See McKesson Corp. v. Deparment of Alcoholic Beverages \& Tobacco. 496 U S. 18.27 n.8 (1990) In none of the cases relied on by the Court which were brought against a state or state agency (as opposed to a state official or a local government) seeking a refund of back taxes was there any indication that the state had assered sovereign immunity as a defense to the state coun action. See id 
The suggestion that revenue officers are personally liable to taxpayers if the taxes were collected pursuant to laws that turned out to have been invalid might strike some readers as odd, but from our earliest days, the mechanism for challenging the legality of taxes was a suit against the tax collector for money had and received. ${ }^{32}$ Granted, our tax collection system today, both state and federal, differs in significant respects from the system that prevailed in those early days, and these differences make the officer-liability regime appear inapt. Then, taxes were collected by a revenue officer whose relation to the state was closer to that of an independent contractor than to that of an employee. The collector was entitled to retain the funds, if paid under protest, pending a judicial decision on their legality. ${ }^{393}$ Today, there is no longer a particular government official to whom one pays a tax, and against whom one might proceed personally to recover amounts paid under duress; we are instead required, under pain of significant penalties, to pay our taxes at a specified time directly to the treasury. Under the current scheme, we would be hard pressed to identify the state official to hold personally responsible for an invalid tax law, and, beyond that, it seems unfair to hold any individual functionary personally liable for the unconstitutionality of the tax laws she enforces.

These changes, however, can be fully accommodated by the interpretation of $M c K e s s o n$ advocated here. McKesson, construed as an official liability case, insists that the Constitution requires that there be a state official against whom someone who is unlawfully deprived of liberty or property may recover damages when the victim had no predeprivation opportunity to test the deprivation's legality, but it goes on to recognize that the state may consent to substitute itself as the defendant. By recognizing a constitutional right to damage relief against an officer, McKesson insists that the state's power to immunize its officials is contingent on the state's agreement to take on the whole of the officials' constitutionally imposed liability. Florida made such provision by establishing a procedure for challenging the legality of a tax in a suit against the state agency responsible for collecting the tax, an agency that would otherwise have been immune under the Eleventh Amendment. $M c K e s s o n$, construed to recognize a constitutional right of action against the officer, makes this waiver of sovereign immunity a necessary condition of the withdrawal of the right of action against the officer. ${ }^{394}$

392. See, e.g., Elliott v. Swartwout, 35 U.S. (10 Pet.) 137 (1836); see also Louis Jaffe, Suits Against Governments and Officers: Damage Actions, 77 HARV. L. REV. 209, 227-28 (1963) (discussing common law suits against tax collectors).

393. See generally Cary v. Curtis, 44 U.S. (3 How.) 236 (1845); Jaffe, supra note 392.

394. Henry Hart anticipated this interpretation of McKesson in his Dialogue, where he wrote:

Wherever the applicable substantive law allows [a personal action against an official who commits a wrong in the name of the Government], the Government may be forced to protect its officers by providing a remedy against itself. The validity of any protection it tries to give may depend on its providing such a remedy.... Consider, for example, the possibility that 
Does this mean that a state would be free to set limits on its consent to be sued and tell taxpayers that if they do not approve, they are free to pursue their constitutional right of action against the state official? ? $^{395}$ In theory, yes. However, a state court's construction of a general consent to suit for a refund as in fact permitting less relief than what the Constitution would require in a suit against the officer would rightly be held by the Supreme Cour to be novel, unforeseen, and thus inadequate to bar relief against the state when the tax had been paid before the novel construction was announced. ${ }^{36}$ More importantly, the Court would rightly regard the changes that have occurred in the state's tax collection procedures, such as the requirement that taxes be paid directly to the treasury rather than to any particular state official, as placing an undue burden on the constitutional right of action against the officer. It might accordingly require any state that wishes to return to that regime to do such things as specify clearly which officers are to be liable. This would, among other things, enable the responsible official to take steps to prepare for such liability, such as procuring an indemnity agreement from the state or insurance. As any sane officer faced with the prospect of personal liability in these circumstances would insist on some such arrangement, the state will wind up bearing the cost indirectly anyway. For this reason, the likelihood that the state will go through the trouble of reviving the long-dead official-liability regime in the tax area is extremely low.

Doctrinally, it might be objected that the construction of McKesson defended here comes close to adopting the position of Justice Story, dissenting in Cary v. Curtis. ${ }^{397}$ Can' involved a federal statute enacted to deal with a problem that had arisen under the traditional tax collection scheme. As noted above, the tax collectors traditionally retained any funds paid under protest pending adjudication of the legality of the tax. This practice delayed significantly the government's access to the collected funds, and so Congress passed a law requiring tax collectors immediately to turn over the funds to the

summary collection of taxes might be invalid if the Govemment did nol wave its immunity to a suit for refund.

Henry M. Hart, Jr., The Power of Congress to Limit the Jurtsdiction of Federal Courns. An Exercise in Dialectic, 66 HARV. L. REV. 1362, 1370 (1953). McKesson as interpreted here. would forufy Harr's premise, for it would establish that the Constitution itself requires the avalabulity of a remedy aganst the officer in cerain circumstances. (Although Han did not expressly so state, this may in faet have been his position, for it is not clear what else could have led him to the conclusion that the government's refusal to consent to a refund action might be "invalid.")

395. Cf. McKesson Corp. v. Department of Alcoholic Beverages \& Tobacco. 496 C.S. 18. 49 n.34 (1990) (raising similar argument that state's waiver of sovereign immunity did not apply when taxpayer had passed on burden of tax; argument was rejected by Supreme Coun as misdesenpuon of state law)

396. See NAACP v. Alabama ex rel. Patterson, 357 U.S. 449 (1958). The Coun in Reich v. Collins, 115 S. Ct. 547, 551 (1994), invoked this line of cases in rejecting the Georgia Supreme Court's holding. unsupported by prior decisional law, that the exclusive avenue for challenging a tax's legalıty was a predeprivation action. Presumably, however, the Georgia cour's interpretation of Georgla law must be regarded as binding in future cases.

397. 44 U.S. (3 How.) at 236. 
Treasury. The law went on to provide that if the Secretary of the Treasury determined that the tax was not in fact legally owing, he had a duty to refund the amount overpaid. The issue in Cary was whether this statute did away with the taxpayer's right to recover against the collector for money had and received. The majority held that it $\mathrm{did}^{398}$ but Justice Story strenuously objected. Story had constitutional concerns about reading the statute to deny the taxpayer any judicial remedy, leaving him totally at the mercy of the Secretary of the Treasury, and to avoid this problem Story would have construed the statute not to withdraw the common law remedy. Far from undermining the proposed interpretation of McKesson, Justice Story's opinion supports it. Story recognized that the taxpayer did not have a right of action against the sovereign because such relief was barred by sovereign immunity. ${ }^{399}$ Thus, Justice Story's position resembles that of our revised understanding of McKesson both in his insistence on the availability of remedies and in his recognition that in the absence of the government's waiver of sovereign immunity, the remedies are available only against state officials. That Story was in dissent in the case does not undermine the proposed interpretation of McKesson because the majority recognized neither the common law action for money had and received nor a remedy against the government itself. If the majority's position conflicts with the reading of McKesson proposed here, it conflicts even more with the conventional reading of McKesson as requiring relief against the state. ${ }^{400}$ The most relevant aspect of Cary for our purposes, then, is that even the Justices who believed most strongly in the importance of remedies and the rule of law did not assert the availability of a damage remedy against the state itself.

An official liability interpretation of McKesson is supported further by the decisions on which the Court in McKesson relied. After declaring that its due process decision was "rooted firmly in precedent dating back to at least early this century," 401 the first case the Court discussed was Atchison, Topeka \& Santa Fe Railway Co. v. O'Connor. ${ }^{402}$ In that case, the Court upheld the availability of relief against the Secretary of State personally. It noted, to be sure, that it would be "inconceivable" that the state would refuse to reimburse him for the amounts awarded, pointing to a state statute that appeared to

398. After the Cary decision, Congress restored the right of action against the collector. See HART \& WECHSLER, supra note 100 , at 376.

399. See Cary, 44 U.S. (3 How.) at 255 (Story, J., dissenting).

400. The majority's holding can in the end be squared with both interpretations of McKesson, however, if the Court is understood to be relying on the availability of a predeprivation remedy. That is how Henry Hant understood the majority's holding in Cary. See HART \& WECHSLER, supra note 100, at 378 (quoting Henry Hart's Dialogue, supra note 394, at 1370).

401. McKesson Corp. v. Department of Alcoholic Beverages \& Tobacco, 496 U.S. 18, 32 (1990).

402. See McKesson, 496 U.S. at 32, 39, 51 (citing Atchison, Topeka \& Santa Fe Railway Co. v. O'Connor, 223 U.S. 280 (1912)). 
contemplate such reimbursement, ${ }^{403}$ but the remedy the Court recognized was one against the officer. ${ }^{404}$

It is similarly inconceivable, for reasons already discussed, that a state today would opt to revise its laws to relegate taxpayers to suits against revenue officers. Consequently, the distinction between officer liability and government liability in the tax context is one that may safely be overlooked, as the Court did in McKesson, without altering substantive results. But the distinction is still important analytically because it helps explain what the Cour meant when it suggested that the state's consent to suit was relevant to the Supreme Court's appellate jurisdiction. Even more important, the recognition that a state is required by the Constitution to make available a retrospective remedy against its officials tells us exactly the price the states must pay for withholding their consent to suit, and thus to the Supreme Court's appellate jurisdiction. Finally, as discussed below, the official liability interpretation of McKesson has significant implications outside the tax area.

Unless combined with the first reinterpretation, however, this second reinterpretation of McKesson leaves us with the doctrinal problems that originally led us to search for a different interpretation. The two proposed reinterpretations address different doctrinal problems caused by McKesson, so adopting both of them produces twice as much doctrinal coherence as adopting one alone. But the value of the combined reinterpretations exceeds the sum of its parts. That is because the second reinterpretation helps solve what we regarded as the principal shortcoming of the first: its failure to take seriously the McKesson Court's apparent intent to establish a generally applicable remedial rule.

\section{McKesson as a Supremacy Clause Case}

The first reinterpretation of McKesson solved the most serious doctrinal problems posed by the decision, but it did so by interpreting the case as a decision about the remedies required by the dormant Commerce Clause. The problem with this reading of the case is that the opinion says nothing that distinguishes the dormant Commerce Clause from any other constitutional provision, or indeed any other provision of law. The Cour's reliance on the Due Process Clause indicates that the Cour meant its holding to have relevance beyond dormant Commerce Clause cases. But relying on the Due

403. See 223 U.S. at 287.

404. See also American Trucking Ass'n. Inc. v. Scheiner. 483 U.S. 266 (1987) (suit aganst Pennsylvania's Secretary of Deparment of Revenue); Bacchus Imports. Lid. v. Dias, 468 U.S. 263 (1984) (suit against Hawaii's Director of Taxation): Carpenter v. Shaw. 280 U.S. 363 (1930) (sult aganst Oklahoma's State Auditor); Gaar, Scott \& Co. v. Shannon. 223 U.S 468 (1912) (sut agaunst Texas's Secretary of State); Central of Ga. Ry. Co. v. Wright, 207 U.S. 127 (1907) (sult agaunst Georgia's Comptroller General). 
Process Clause produces the doctrinal problems described above. To solve both sets of problems, we might try to find a constitutional home other than the Due Process Clause for the supposed right to damages from the states, a constitutional provision that would allow us to apply McKesson's remedial holding more broadly than just to dormant Commerce Clause cases. But the argument that any provision of the Constitution establishes a general rule that states are constitutionally obligated to pay damages to individuals injured by their violations of law faces a significant embarrassment: Leaving aside McKesson and related due process cases, the only Supreme Court decisions to recognize that states are under a constitutional requirement to pay damages to individuals are the takings cases discussed in Section I.A, and they rely on textual support that does not apply to other constitutional provisions: the Takings Clause's express reference to "compensation." Can it be that the courts for over two centuries have overlooked a more general constitutional requirement that states pay damages? The Eleventh Amendment cases involving the Contracts Clause, including not just Hans but many others as well, ${ }^{405}$ would appear to rule out any such conclusion. ${ }^{406}$

Our second proposed reinterpretation points the way to a solution. McKesson can be understood to establish that governmental violations of the Constitution give rise, as a constitutional matter, to a right of action against responsible state officials. Recharacterizing the decision as an affirmation of the constitutional availability of a damage remedy against state officials who violate the Constitution transforms McKesson from a constitutional oddity into one of a long line of cases throughout our history awarding such damages. McKesson, so interpreted, would be of a piece with such landmark cases as Poindexter, Ex parte Young, and Bivens. ${ }^{407}$ These cases are best understood as recognizing that the constitutional remedy for governmental violations of the Constitution is a remedy against the officials who violated the Constitution, not the governments for whom they work. ${ }^{408}$

If this constitutional right to damages does not have its source in the Due Process Clause, what is its source? The now evident connection between McKesson, Poindexter, and Ex parte Young helps answer this question. These cases make it clear that the Supremacy Clause is both the doctrinal linchpin for

405. See Fletcher, Historical Interpretation, supra note 7, at 1123 n.338.

406. Even diversity theorists such as William Fletcher concede that the intent of the Framers of the Eleventh Amendment and the Supreme Court's decisions rule out the conclusion that damages against the states are available under the Contracts Clause. See id. at 1122-24. But cf. Wolcher, supra note 28 (arguing that courts should allow damage remedy against states for constitutional violations that are enforceable in state court with Supreme Court review).

407. Bivens v. Six Unknown Named Agents, 403 U.S. 388 (1971) (recognizing federal right of action for damages against federal officials who violate Fourth Amendment); see also FDIC v. Meyer, 510 U.S. 471 (1994) (declining to recognize federal right of action for damages against federal agencies that violate Constitution).

408. This interpretation of Poindexter, Ex parte Young, and Bivens is defended at greater length in Vázquez, supra note 80 . 
the availability of relief against state officials and the source of the policy driving the result.

Doctrinally, the Supremacy Clause nullifies any state laws that might be read to authorize the challenged conduct and removes any defense of official authority or sovereign immunity, thus leaving the official subject to common law remedies. ${ }^{409}$ These early cases suggest that the Supremacy Clause merely withdraws a defense, leaving the common law as the affirmative source of the remedy against the official, but this understates the role the Supremacy Clause played in these cases. ${ }^{410}$ The cases make it clear that the Supremacy Clause requires the states to make available against state officials whatever remedies would have been available under the common law against private parties who caused a similar sort of injury. It is for this reason that state officials are liable even if state law provided them with some sort of immunity from liability. In a very real sense, therefore, the source of the remedy against the state official in these cases is the Supremacy Clause. ${ }^{412}$

As to the constitutional policy being advanced by such remedies, the Poindexter Court had this to say:

Of what avail are written constitutions whose bills of right for the security of individual liberty have been written, too often, with the blood of martyrs shed upon the battle-field and the scaffold, if their limitations and restraints upon the power may be overpassed with impunity by the very agencies created and appointed to guard, defend, and enforce them ... ? And how else can these principles of individual liberty and right be maintained, if, when violated, the judicial tribunals are forbidden to visit penalties upon individual offenders, who are the instruments of wrong, whenever they interpose the shield of the State? The doctrine is not to be tolerated. The whole frame and scheme of the political institutions of this country, State and Federal, protest against it.... [The Constitution] creates a government in fact, as well as in name, because its Constitution is the

409. See Poindexter v. Greenhow, 114 U.S. 270, 290 (1885) ("That which . . is unlawful because made so by the supreme law, the Constitution of the United States, is not the word or deed of the State. but is the mere wrong and trespass of those individual persons who falsely speat and act in its name."): id. at 288 (holding that because of constitutional violation, state official "stands . . strupped of his offictal character, and, confessing a personal violation of the plaintiff's rights for which he must personally answer. he is without defence"). Similar language was used in Ex parre loung. 209 U.S. 123. 159-60 (1908).

410. It is also misleading to say that the contours of the remedy were at this ume not considered to be a matter of federal law, for during the reign of Swifi $v$. Tyson. $4 \mid$ U.S. (16 Pet.) 1 (1842), the distunction between the common law and federal law was not as clear as it is now.

411. See, e.g., Georgia R.R. \& Banking Co. v. Redwine, 342 U.S. 299.305 n. 17 (1952). General O1l Co. v. Crain, 209 U.S. 211 (1908). See generally. Vízquez, supra note 80. at 120-26.

412. Gradually, "[b]y almost imperceptible steps," the Court abandoned thus common-law model and "[came] to treat the remedy of injunction as conferred directly by federal law for abuse of state authonty which in the view of federal law ought to be remediable." Henry M. Har. Jr. The Relations Benieen Srate and Federal Law, 54 COLUM. L. REV. 489, 524 (1954). The Bivens decision reflects the completion of this transformation with respect to the damage remedy. I examine the transformation in grester depth in Vâzquez, supra note 80 , at 121-42, 178-84. 
supreme law of the land ... and its authority is enforced by its power to regulate and govern the conduct of individuals, even where its prohibitions are laid only upon the States themselves. The mandate of the state affords no justification for the invasion of rights secured by the Constitution of the United States; otherwise that Constitution would not be the supreme law of the land. ${ }^{413}$

The heart of the proposed reinterpretation of McKesson is well encapsulated in the Court's powerful affirmation of the need for retrospective remedies to give efficacy to constitutional norms: The need is great, to be sure, but the Constitution's method of securing this efficacy, "even where the prohibitions are laid upon the States," is to "regulate and govern the conduct of individuals" and to "visit penalties upon individual offenders who are the instruments of the wrong." (By "individuals," the Court clearly is referring to individual state officials.) Visiting penalties upon the states themselves was either not perceived to be necessary to give the Constitution the desired efficacy, or was understood to be forbidden. It is noteworthy that the Justices who wrote and concurred in this forceful paean to the importance of constitutional remedies also concurred in the Hans decision. And it is even more significant that no one suggested the possibility of obtaining these remedies from the state itself in Poindexter, even though the suit was brought and litigated in the state courts. ${ }^{414}$

There is, in addition, significant support in the statements of the Framers of the original Constitution for the proposition that they contemplated that the obligations of the state governments would be enforced in court by means of suits against state officials, not against the states themselves. After discussing the methods by which the Constitution would provide for the efficacy of federal obligations, the Founders decided not to retain the scheme set up by the Articles of Confederation, under which federal norms were enforceable only against the states as political bodies. They opted instead to give Congress the power to make federal legislation operative on individuals and enforceable in the courts against individuals. Although the Founders were making a broader point than the one we are considering, their expressed reasons for preferring the new system are relevant here as well. The Founders rejected the prevalent system because they believed that duties could be enforced against political bodies only through military force. Against individuals, by contrast, duties could be enforced through the courts:

413. Poindexter, 114 U.S. at 291-92.

414. In Vázquez, supra note 80 , I offer a more extensive textual and jurisprudential defense of the idea that the Supremacy Clause is the source of a constitutional law of remedies for constitutional violations, as well as a more detailed doctrinal defense of the proposition and an examination of the doctrinal implications of adopting the theory. 
Hence we see how necessary for the Union is a coercive principle. No man pretends the contrary: we all see and feel this necessity. The only question is, Shall it be a coercion of law, or a coercion of arms? There is no other possible alternative. Where will those who oppose a coercion of law come out? Where will they end? A necessary consequence of their principles is a war of the states one against the other. I am for coercion by law-that coercion which acts only upon delinquent individuals. This Constitution does not attempt to coerce sovereign bodies, states, in their political capacity. No cocrcion is applicable to such bodies, but that of an armed force. If we should attempt to execute the laws of the Union by sending an armed force against a delinquent state, it would involve the good and the bad, the innocent and guilty, in the same calamity.

But this legal coercion singles out the guilty individual, and punishes him for breaking the law's of the Union. ${ }^{\text {tis }}$

The fear that any attempt to enforce federal laws against the states as political bodies would necessarily involve military force appears in retrospect to have been exaggerated, but what is important for present purposes is that the Founders feared such violence and for that reason rejected the notion of enforcing federal obligations against the states as collective political bodies. Moreover, their discussions reveal that they viewed "legal" obligations as by their nature enforceable in courts, and they appeared to assume that judicial proceedings could be maintained only against individuals. ${ }^{.16}$

Justice O'Connor's majority opinion in New York v. United States ${ }^{317}$ relied in part on this history to justify the holding that Congress generally may not impose obligations on states as states ${ }^{48}$ (although, as noted, she somewhat inconsistently upheld Garcia insofar as it allowed Congress to regulate states as part of a broader class). ${ }^{419}$ These statements do not, however, support the Court's holding. After all, the Constitution itself imposes obligations directly on the states. It is thus difficult to interpret these statements as contemplating that there would be no federal obligations operative on states as political bodies. The Framers' statements are best taken as statements about remedies and enforcement, not the existence vel non of legal obligations. The Framers' concerns support the conclusion that the federal

415. 2 DEBATES, supra note 231, at 197 (statement of Oliver Ellsworth) (emphasis added). Willam Samuel Johnson's statement to the Connecticut ratufying convention was to the same effect. "The force. which is to be employed [to carry out the law's of the Union] is the energy of Law': and this force is to operate only upon individuals, who fail in their duty to their country." Willam Samuel Johnson. Speech in the Connecticut Ratifying Convention (Jan. 4. 1788), reprinted in 15 ThE DOCUMEsTary History of THE RATTFICATION OF THE CONSTITUTION 248-49 (John P. Kaminski \& Gaspare J. Saladino eds. 1984).

416. See generally Vázquez, supro note 105, at 1097-101 (argung that Framers vıewed laus as operating on individuals and being enforceable in cours).

417. 505 U.S. 144 (1992).

418. See id. at $163-66$.

419. See supra text accompanying note 99. 
obligations of the states-those imposed by the Constitution and those imposed on the states by Congress-are, as a constitutional matter, to be enforced in suits against the individual state officials who violate federal law. In other words, the remedy the Constitution contemplates for the enforcement of federal obligations of the states (and the federal government, too) is a remedy against individual officials.

Interpreting McKesson as a Supremacy Clause case establishing a constitutional right of action for damages against state officials responsible for violating federal law is faithful to as much of the Court's decision in the case as possible while avoiding the doctrinal problems that led us to reject the due process rationale. Like the due process rationale, the Supremacy Clause rationale allows us to give effect to the Court's evident intent to articulate a generally applicable remedial principle, but the Supremacy Clause rationale is better than the due process rationale at accommodating a congressional determination that damages should not be available for violations of federal statutes. That is because the purpose of the damage remedy under the Supremacy Clause rationale is to ensure the efficacy of federal law. If Congress passes a statute but determines that a private right of action for damages should not be available, that is presumably because Congress has established alternative mechanisms that it believes adequate to secure the efficacy of that statute. Nothing in the Supremacy Clause makes the courts a better judge of that question than Congress. It is conceivable that Congress would pass a law and preclude private damage actions because it does not want the statute to be "fully" enforced. The Supremacy Clause rationale can accommodate that judgment as well. If Congress denied a private damage action because it was only half-heartedly behind the federal statute, then that is presumably because the nation is only half-heartedly behind the statute. In such circumstances, half-hearted enforcement is the "correct" degree of enforcement; any more would be overenforcement. ${ }^{420}$

This sort of flexibility would be unavailable if the right to damage were located in the Due Process Clause. As discussed, the doctrinal gloss that has accreted around the Clause requires, among other things, a strict separation between the concepts of substance and procedure. Thus, if the Due Process Clause conferred a right to damages (something it could do only if we classified damages as "procedure") then it would not be within Congress's

420. There are, admittedly, rule-of-law considerations that might lead one to disable Congress from enacting laws that it does not want vigorously enforced. Most significantly, respect for law is reduced if the citizenry observes a proliferation of "laws" that are frequently violated with no consequences. It is to protect this rule-of-law value that I argue that the Supremacy Clause should be read to cstablish a presumption of a private right of action for damages against state officials who violate federal statutes and treaties. See Vázquez, supra note 80 , at 74-75. But the decisions discussed at the end of Part IV rulc out the conclusion that Congress lacks the power under our Constitution to deny a private right of action to beneficiaries of the statutes it passes. For further discussion of this issue, see supra note 21 . 
power in creating a substantive obligation to deny such relief to persons injured by a statutory violation.

With respect to federal statutes, the private damage action grounded in the Supremacy Clause can at best be presumptive-i.e., subject to a congressional negation. By contrast, a federal statute purporting to cut back on available remedies for constitutional violations by state or federal officials would raise grave concerns under the Supremacy Clause. The Supremacy Clause right of action for damages for constitutional violations is accordingly one that would not be subject to congressional negation. It is this aspect of McKesson, interpreted as a Supremacy Clause case about official liability, that I regard as most important. Indeed, for this reason, I regard the adoption of this interpretation of McKesson to be far more important from a rule-of-law perspective than adoption of the diversity interpretation of the Eleventh Amendment would be. Under the diversity view, as currently embraced by at least three of the dissenters in Seminole Tribe, the availability of relief against the states depends in the end on a congressional decision to withdraw the states' sovereign immunity. A remedy for constitutional violations that depends on Congress's affirmative action is far from ideal, as Congress, being the majoritarian branch, is unlikely to pay due regard to the countermajoritarian norms of the Constitution. The courts and private parties are the best defenders of these norms, and McKesson, if read to suppor the existence of a constitutionally based private right of action, would go far to advance this ruleof-law goal.

Reading McKesson to confer a right to damages against officials rather than the state itself would also make sense of the Cour's own statement that the Supreme Court's power to review state cour judgments in suits against states is contingent on the state's assent. We give effect to the assent language by recognizing that the state's decision to permit a suit against itself is purely voluntary; the Constitution does not subject the state to liability. We nevertheless give effect to the McKesson Court's apparent conviction that a remedy in that case was required by recognizing that the Constitution requires a damage remedy against the officer. The state does not have to consent to a suit against itself, but it must do so if it wishes to shield its officers from liability. As it will often wish to do so, the interpretation of McKesson defended here will place some pressure on the states to consent to federal liability.

Interpreting McKesson as a Supremacy Clause case would mean that the damage remedy it recognizes would not apply to deprivations of property that violate state law. This may well reduce the interpretation's appeal. I am sympathetic to the view that when the state requires you to pay taxes first and litigate later, the state should be required to make available a full refund remedy not only when the tax is determined to have violated federal law, but 
also when the tax turns out to have been invalid because it violated state law or when the tax was found not to be owing because state law did not require its payment in the first place. ${ }^{421}$ Such a rule would admittedly protect rule-oflaw values such as the interest in procedural regularity. These are the same values that underlie the Arnett/Loudermill line of cases, but, for reasons already discussed, the claim that the Due Process Clause unyieldingly protects these values is difficult to square with cases recognizing the legislature's power to deny private remedies for the violation of the obligations it creates. The latter cases suggest that the protection of those rule-of-law values has been left by our Constitution, to some extent at least, to the legislature that created the substantive norm.

At any rate, despite its express reliance on the Due Process Clause, the McKesson opinion in the end appears not to go so far as to affirm the constitutional need for a refund when the tax violated only state law. All of the precedents the Court regarded as support for the conclusion that the states are obligated to provide a refund remedy were cases in which the tax was alleged to have violated federal law. At several points, the Court described its holding

421. Because by hypothesis the taxpayer is making the initial findings of fact and application of law to fact in these cases, it is difficult to think of a situation in which the taxpayer would have cause to complain about having been required to pay taxes that the statute does not actually purport to require. The problem would arise only if some state agency interpreted the statute one way and threatened substantial penalties if the taxes covered by such interpretation were not paid, but the taxpayer disagrecs with the interpretation and uitimately gets a court to agree. Assume, for example, that the state agency responsiblc for taxes has interpreted the state law to require a certain form of accounting and the taxpayer believes that that is an erroneous interpretation of the state statute. If the state requires you to pay first and litigate later, then it may be unfair for the state not to offer a refund if the court agrees with the taxpayer and not the agency. Notice that this analysis relies on the availability of judicial review of agency interpretations of statutes. To say that the Due Process Clause requires a remedy in these circumstances would appear to read that Clause as imposing on the states a very particular system of separation of powers-a system, for example, that denies the state legislature the power to delegate to the agency the authority to interpret state statutes authoritatively pending a contrary interpretation by the judicial branch. It is difficult to maintain that the Constitution requires the states even to give their cours the power to reject the interpretations given to statutes by state agencies. If so, it is even more difficult to read into the Constitution a requircment that state court rejection of such interpretations be given retroactive effect.

There is a more plausible argument to be made that the Due Process Clause requires the state to adhere roughly to some substantive norm when it deals with its citizens, that is, that it not act in an arbitrary or capricious way. In this respect, a state's violation of its own law that results in a deprivation of liberty or property implicates the Due Process Clause and, it might be argued, requires the state to offer a postdeprivation damage remedy. This was, of course, the issue in the ParrattZinermon line of cases. If those cases are read to hold that the Due Process Clause requires a damage remedy for the violation of state laws that do not confer a damage remedy, they would be consistent with Armett/Loudermill but would conflict with Sea Clammers and the other cases discussed above. Holding that the right to damages, if any, comes from the Supremacy Clause rather than the Due Process Clause would appear to reject a federal constitutional right to damages for the violation of state law. Perhaps a constitutional right to damages under the Supremacy Clause might be said to exist when the state acts in an arbitrary way, on the theory that such conduct violates substantive due process. This would deal with the Sea Clammers line of cases by accepting that damages may not be available where a statute that denies damages was not complicd with (so long as the failure to comply was not so egregious as to be "arbitrary"), while satisfying the intuition that the Constitution confers protection against arbitrary governmental action and should provide a damage remedy for it. Scholars have argued that the Parratt line of cases should be understood as substantive due process cases. See, e.g., Falion, supra note 335; Monaghan, supra note 352. 
as a requirement that the state provide a remedy for its "unconstitutional" deprivations. ${ }^{422}$ In its final paragraph, it summed up its holding as follows:

When a State penalizes taxpayers for failure to remit their taxes in timely fashion, thus requiring them to pay first before obtaining review of the tax's validity, federal due process principles long recognized by our cases require the State's postdeprivation procedure to provide a "clear and certain remedy" for the deprivation of tax moneys in an unconstitutional manner. ${ }^{43}$

These statements suggest that the remedial principle the Court recognized extends only to taxes that violate the federal Constitution. ${ }^{42}$ Other parts of the opinion suggest that the principle applies to taxes that violate federal statutes as well. ${ }^{425}$ Finally, in Reich $v$. Collins, ${ }^{126}$ the Court stated that McKesson and the cases McKesson relied on "stand for the proposition that 'a denial by a state court of a recovery of taxes exacted in violation of the laws or Constitution of the United States by compulsion is itself in contravention of the Fourteenth Amendment."',27 The Supremacy Clause rationale explains why the refund remedy is required when the deprivation violated the federal Constitution and federal statutes, but not when the deprivation merely violated state law. If the basis of the refund remedy were the Due Process Clause, on the other hand, it would be difficult to explain why the remedy is limited to deprivations that are unlawful because they violate federal law. The Supremacy Clause rationale thus helps explain this feature of the McKesson and Reich decisions as well.

\section{What Remains of the Forum-Allocation Interpretation?}

I offer this rather extended reinterpretation of McKesson's due process holding not just because of its importance for our law of constitutional remedies, but also because of what it tells us about the nature of Eleventh

422. See McKesson Corp. v. Deparment of Alcoholic Beverages \& Tobacco, 496 U.S 18. 31 (1990) (holding that Due Process Clause "obligates the Statc to provide meanungful backward-looking relief to rectify any unconstitutional deprivation"); id. at 46 (referring to "unconsututional depnvilton of propery")

423. Id. at 51 (emphasis added) (citation omitted).

424. The Court cannot be understood to be saying that the taxes were "unconsututuonal" in these cases because the state denied a refund remedy. The Court was discussing what the Due Process Clause required. and it made it quite clear that the Due Process Clause is sausfied in tax cases even if the state does not offer a predeprivation hearing, but only if it provides a refund remedy. Its statements that a refund remedy is required when the tax is "unconstitutional" must therefore mean that the remedy is required when the tax violates some other provision of the Constitution.

425. This is suggested by its quotation from Carpenter s Shaw. 280 U.S. 363.369 (1930), see 496 U.S. at 34 .

426. 115 S. Ct. 547 (1994).

427. Id. at 549 (quoting Carpenter, 280 U.S at 369) (cmphasis added) 
Amendment immunity. To say that the Constitution relies on private damages actions against state officials as the mechanism to give efficacy to the federal obligations of the states is not necessarily to say that the Constitution disables Congress from subjecting the states themselves to damage liability. It is quite plausible to conclude that the Constitution sets up a default system for enforcing federal norms--suits against officials-but gives Congress the power to supplement that system by making the states themselves liable. Neither the cases recognizing the liability of officials for constitutional violations, nor the absence of cases finding the states themselves liable, is in direct conflict with the idea that Congress has the power to make the states themselves liable. The evidence of Framers' intent I pointed to above is equivocal on this score as well. The Framers were clearly concerned that enforcing federal norms against states as political bodies would require the frequent exercise of military force, with undesired consequences, but it is also evident that they contemplated that military force would sometimes be necessary to enforce federal law against recalcitrant states. The question is whether they intended to establish a constitutional principle requiring that federal norms be enforced against state officials first, a course likely to obviate resort to military force, or instead left it to Congress to decide whether the risk of resort to military force was sufficiently small in a given context that placing a liability on states should not be a concern. Their statements do not answer that more specific question.

My reinterpretation of McKesson's due process holding as affirming the constitutional availability of damage relief against state officials who violate federal law does not, therefore, provide affirmative support for the conclusion that Congress lacks the power to subject the states to damage liability to individuals. It does, however, strengthen the case for the immunity-fromliability view. By helping explain the Court's reference to the state's "assent" in that case, it makes it possible to read the case as conditioning the Supreme Court's jurisdiction on the state's consent to being sued in the state courts. As discussed above, if the states have the power to evade Supreme Court review by refusing to consent to suits against them, then any liability Congress imposes on the states will be illusory. This interpretation of McKesson, in turn, removes McKesson and Reich from the ranks of the cases that support the forum-allocation view and adds them to the already impressive array of authority supporting the immunity-from-liability interpretation. In this Section, I consider the support for the forum-allocation view that remains after the defection of McKesson and Reich.

I begin by discussing how the abrogation reductio fares under the immunity-from-liability view. In Part IV, I concluded that if we make certain assumptions about the scope of the Section 5 enforcement power, we can avoid the abrogation reductio even if we assume that the Due Process Clause requires a damage remedy. We avoid the reductio on that assumption only if we 
assume the correctness of the forum-allocation interpretation, for the price the states must pay to avoid congressional abrogation of their immunity is to submit to liability and suit in their own courts. Can the reductio be avoided if we assume that the Eleventh Amendment confers an immunity from liability? If we assume that the Eleventh Amendment prevents Congress from subjecting states to damage liability and that the Due Process Clause does not itself require a damage remedy for state deprivations of property, it seems easier to avoid the reductio. It is true that a patent is still property and that states are still required to provide some sort of protection for it. It is also true that under this interpretation state officials may be personally liable for patent infringement, at least if Congress makes them liable. If we assume that Eleventh Amendment immunity is immunity from liability, then Congress can "abrogate" it, meaning it can subject the states to liability, only if the states fail to take the required steps to protect the underlying right. Note that these steps do not include subjecting itself to damage liability. The obligation of the officials to pay damages does not come from the Due Process Clause, so the state's failure to entertain damage suits against its officials in its courts would not support an abrogation power. ${ }^{428}$ Of course, some of the broader theories of congressional power under Section 5 might support a power to abrogate immunity even in these circumstances, given that a property right concededly exists. For this reason, avoiding the reductio will in the end depend either on the Court's narrow construction of Section 5 generally or on its exemption of procedural due process cases from whatever broad enforcement power may exist in other contexts. At any rate, avoiding the reductio is no more difficult under the immunity-from-liability interpretation than under the forum-allocation interpretation, and, depending on how the Cour interprets Section 5, it may be easier under the immunity-from-liability view.

Apart from the dicta in such cases as Employees and Atascadero, ${ }^{429}$ the remaining support for the forum-allocation view consists of the takings cases $^{430}$ and Hilton. ${ }^{431}$ Can the takings cases be reconciled with an interpretation of the Eleventh Amendment as establishing an immunity of states from liability to individuals? Perhaps not, as these cases establish that the states must provide a monetary remedy when they take property for a public

428. The states may be required to enterain such acuons in their cours anyway, see Howlet $\vee$ Rose. 496 U.S. 356, 383 (1990); Testa v. Katt, 330 U.S. 386, 394 (1947), but this obligation does not come from the Due Process Clause. The Supreme Coun's power to review cases from the state courts aganst state officials is not affected by the Eleventh Amendment, as such suits are not suits aganst the state For the same reason, the lower federal courts can be given original junsdiction over such cases

429. I refer here to the Aiascadero footnote and Justuce Marshall's analysis in Employees. Sec supra Section I.B. As noted above, Atascadero may in fact be consistent with the immunity-from-hability interpretation of the Eleventh Amendment. See supra note 144: see also supra notes 390-91 (discussing compatibility with immunity-from-liability view of other cases someumes cted as suppon for forumallocation view).

430. See supra Section II.A.

431. See supra text accompanying notes 144-51; unfra text accompanying notes $433-40$ 
purpose. Conceivably, these cases might be explained on a "consent" theory similar to that of the proffered interpretation of McKesson, since all states permit inverse condemnation actions, but if these cases turned on consent, then the states could defeat the remedy, or at least Supreme Court enforcement of the remedy, simply by repealing their laws on that subject. A more promising way to reconcile the takings cases with the immunity-from-liability interpretation of the Eleventh Amendment would be simply to regard the Takings Clause as sui generis in that it is the only constitutional provision that expressly entitles individuals to retrospective relief from the states. ${ }^{432}$ As such, it may be said to establish a limited constitutional exception to the immunity from liability that the Eleventh Amendment otherwise confers.

That leaves Hilton. In that case, a bare majority of the Court held that Congress subjected the states to damage liability to individuals when it enacted FELA, ${ }^{433}$ a liability that because of the Eleventh Amendment, is not enforceable in the lower federal courts. The Court also indicated clearly that the Supremacy Clause requires the state courts to enforce that liability. ${ }^{434}$ It would seem inconsistent with the latter statement to permit the state courts to decline to provide the remedy on sovereign immunity grounds. The Court's citation of Howlett v. Rose $e^{435}$ is an indication that it believed that a state's invocation of sovereign immunity for this purpose would violate the Supremacy Clause. ${ }^{436}$

However, the Court did not say anything about its own jurisdiction to review state court decisions in FELA cases. The state court in Hilton did not dismiss on sovereign immunity grounds; instead, it dismissed on the merits, holding that Congress had imposed no liability. ${ }^{437}$ The Supreme Court reviewed that judgment, but its exercise of appellate jurisdiction could be reconciled with McKesson and Seminole Tribe on the ground that the state had consented to the suit by not raising a sovereign immunity defense. If so, then a future state court could gut the state's duty to pay damages under FELA simply by invoking the state's own law of sovereign immunity and thus making it clear that it does not consent to the suit.

If the Court were to reconcile Hilton with Seminole Tribe in this way, it would be affirming on the one hand the state courts' obligation under the Supremacy Clause to afford a remedy and their duty not to refuse to do so on sovereign immunity grounds, but on the other hand, it would be recognizing

432. See HART \& WECHSLER, supra note 100 , at 849.

433. See Hilton v. South Carolina Pub. Rys. Comm'n, 502 U.S. 197, 200 (1991).

434. See id. at 207.

435. 496 U.S. 356, 367-68 (1990), cited with approval in Hilton, 502 U.S. at 207.

436. But cf. Hess v. Port Auth. Trans-Hudson Corp., 115 S. Ct. 394 (1994) (stating in FELA case that applicability of Eleventh Amendment relegates claimants to suits in state courts "if the state permits"); supra text accompanying note 255 .

437. See Hilton, 502 U.S. at 200. 
its own powerlessness to intervene where the states have violated that duty. Its affirmation in Hilton that states are under a federal obligation to pay damages to individuals under FELA might thus be interpreted as a rejection of my earlier dismissal of federal liabilities not enforceable in any federal court as no liability at all. If so, the refusal of the Justices in the Seminole Tribe majority to go along with my characterization would be in keeping with their confidence in the state courts' ability and willingness to enforce federal law faithfully. Like Chief Justice Marshall, I find such confidence to be misplaced, especially in this context, not because I hold a particularly unfavorable opinion of the character of state court judges, but because I hold a realistic opinion regarding the strengths and weaknesses of human beings generally. Persons whose jobs are dependent on the favorable opinion of the state's more overtly political branches are unlikely to be reliable enforcers of obligations imposed on state governments from without. To give Congress the power to obligate the states to pay damages to individuals and to expect the state courts to enforce this obligation without monitoring by a federal cour calls to mind an aspect of the scheme set up by the Articles of Confederation that Hamilton (and others) decried as "imbecili[c]":438

There was a time when we were told that breaches by the States of the regulations of the federal authority were not to be expected; that a sense of common interest would preside over the conduct of the respective members, and would beget a full compliance with all the constitutional requisitions of the Union. This language, at the present day, would appear as wild as a great part of what we now hear from the same quarter will be thought, when we shall have received further lessons from that best oracle of wisdom, experience. It at all times betrayed an ignorance of the true springs by which human conduct is actuated, and belied the original inducements to the establishment of civil power. Why has government been instituted at all? Because the passions of men will not conform to the dictates of reason and justice without constraint. ${ }^{439}$

Having learned this lesson so recently, it is highly unlikely that the Founders would have given the federal government the power to obligate the states to pay damages to individuals without also giving the federal courts the power to enforce that obligation should the states prove recalcitrant. The Court would be truer to the Founders' convictions if it either overnuled Hilion (insofar as it holds that Congress has the power to impose damage liability on the states)

438. The Federalist No. 15, at 107 (Alexander Hamilion) (Clinton Rossiter ed.. 1961).

439. Id. at 110. It is worth recalling here as well Madison's statements in The Federaltst No SI: "[W]hat is government isself but the greatest of all reflections on human nature? If men were angels, no government would be necessary. If angels were to govern men. neither external nor intemal controis on government would be necessary." THE FEDERALIST No. 51 . al 322 (James Madison) (Clinton Rossiter ed., 1961). 
or rejected the "consent" requirement alluded to in McKesson and Seminole Tribe. To do neither would be to recognize the theoretical existence of a legal obligation that would in reality have the force of a dead letter. ${ }^{40}$

\section{THE ElEVENTH AMENDMENT AS IMMUNITY FROM LIABILITY: IMPLICATIONS, OPEN QUESTIONS, AND COMPATIBILITY WITH THE RULE OF LAW}

This Article began by noting the serious questions that have long been raised about the Eleventh Amendment's conformity with the nation's rule-oflaw aspirations. The forum-allocation interpretation of the Amendment would have greatly alleviated these problems, if not totally cured them. This Part assesses the nature and seriousness of the rule-of-law problems that would remain if the Court were to adopt the immunity-from-liability interpretation of the Eleventh Amendment. I conclude that as long as the Constitution continues to be interpreted to authorize private suits against state officers who violate federal law, an interpretation of the Constitution as barring private damage actions against the states themselves does not raise severe rule-of-law problems. Indeed, as noted, an interpretation of McKesson and such other cases as Poindexter, Ex parte Young, and Bivens as recognizing a right of action against state officials who violate the Constitution, a right of action grounded in the Constitution itself and not subject to congressional narrowing, would do more to advance the rule of law than would adoption of the diversity interpretation of the Eleventh Amendment, which, as embraced by the dissenting Justices in Seminole Tribe, would recognize a remedy against the states only if Congress provides one. I do not, of course, maintain that the two are mutually exclusive, but I do suggest that the rule of law would be better served if energies that have heretofore been directed at defending the diversity and forum-allocation theories were directed instead to exploring the remedial avenues that may remain open under an official-liability regime.

What are those remedial possibilities for, say, an individual who claims that a state is infringing her patent? First, as the Court indicated in Seminole Tribe, the Eleventh Amendment does not bar the federal courts from awarding injunctive relief against state officials who violate federal laws. ${ }^{441}$ Although

440. The Hess opinion shows how easy it is for Justices who lack confidence in the state courts' willingness to enforce federal liabilities of the states to equate the lack of Supreme Court review over a certain category of case with the absence of a state court obligation to entertain such cases. See Hess, 115 S. Ct. 394 ; supra notes $255-63$ and accompanying text.

441. See Seminole Tribe v. Florida, 116 S. Ct. 1114, 1131 n.16 (1996). In International Postal Supply Co. v. Bruce, 194 U.S. 601 (1904), and Belknap v. Schild, 161 U.S. 10 (1896), the Court held that cven though the patent law's prohibition of infringement applies to the federal government, the sovereign immunity of the United States precludes courts from enjoining federal officials from using federal property that infringes a patent. Given Congress's power to waive sovereign immunity, it is difficult to conceive of this as a constitutional holding. The Cour in Belknap did, however, rely on Eleventh Amendment holdings 
the Seminole Tribe Court's Ex parte Young holding muddies the waters a bit concerning the circumstances in which such relief will be available, it seems clear that such relief is available at least if Congress has clearly so provided. There is some authority for the proposition that monetary sanctions for failure to comply with a prospective court order can be assessed against the state itself, as opposed to the official. ${ }^{\mathbf{4 2}}$ Adoption of the immunity-from-liability interpretation may call into question the vitality of that authority where the order requires compliance with a duty imposed on the state pursuant to Article $I^{443}$ But, at a minimum, a state official who violates a court order not to infringe a patent would be personally subject to contempt sanctions. This appears effective to ensure prospective compliance with the federal obligation not to infringe.

Our analysis of Zinermon in Part IV suggested that the Due Process Clause may impose a duty on states to set up a procedure whereby officials who are contemplating using patented material would be required to obtain preclearance, a procedure that might include notice to the patent holder and an opportunity to adjudicate the patent's validity and whether the contemplated conduct infringes. As noted, it seems odd to read the Due Process Clause to require this procedure when the patent laws require no similar procedure of private parties. At any rate, it appears unlikely that a cour would require the creation of such a bureaucracy when Congress has not so required. This raises the question whether Congress can require that the states set up such procedures. On the one hand, to impose such requirements on the states without imposing parallel requirements on private individuals would appear to single out the state for regulation in violation of New York. On the other hand, it is only because the states are immune from damage liability that Congress would even consider this scheme. Perhaps a congressional requirement along these lines would be upheld by the Court as a valid "enforcement" of the States' due process obligations with respect to an admitted property right.

Congress may additionally have the option of easing standing and ripeness obstacles to injunctive relief. How far the Court would allow it to go in this

\footnotetext{
in reaching its conclusions. See 161 U.S. at 18-23. To the extent that the Coun regarded thus holung as applying as well to the states, the decision would appear to have been superseded by such more recent decisions as the second Pennilurst decision, in which the Coun staled thit when a plantuff sues a stale official alleging a violation of federal law, the federal coun may award an injunction that governs the official's future conduct... . Under the theory of Young. such a sult would not be one aganst the Stale since the federal-law allegation would strip the state of ficer of his offictal authonty " Pennhurst State Sch \& Hosp. v. Halderman, 465 U.S. 102-03 (1981). The aspect of the Belknap decision that does retan current relevance is the Cour's affimation of the availability of damages in an action at law aganst the federal officials responsible for infringing patents. See 161 U.S. at 26.

442. See supra note 108 and accompanying text; see also Maune v: Thiboutot, 448 L.S 1 (1980)

443. To the extent that the Court in these cases relied on the conclusion that Congress abrogated sovereign immunity when it enacted 42 U.S.C. $\$ 1988$ (1994). Semmole Trbe would appear to call into question the cours' power to award such penalties and costs when the foderal law that the state offices violated was enacted by Congress under Anicle I.
} 
direction is unclear after Lujan v. Defenders of Wildlife, ${ }^{444}$ but the concurring Justices seemed to be willing to give Congress substantial leeway. ${ }^{445} \mathrm{It}$ is not clear that this avenue would be productive in the patent context, but Congress may find it useful in other contexts.

Relying on prospective relief only, however, even if broadened in the ways suggested, would still leave states with the ability to violate federal obligations for a time. Such a regime leaves the states with little incentive to take any federal obligations seriously until confronted with a suit seeking to stop an ongoing violation. The state could, without assuming any risk, conduct itself entirely without regard to any possible federal obligations until confronted with a legal challenge. In the meantime, the interests underlying the federal obligation have been compromised.

To address this problem, Congress might impose a penalty for past violations of federal obligations payable to the federal government. It is established that the Eleventh Amendment does not apply to suits by the federal government. The prospect of such a penalty should lead the state to pay more attention to possible federal obligations, but this technique of enforcement could be costly, as it requires setting up a federal bureaucracy to monitor state activities in the area. It has been suggested that the federal government has the power to authorize private parties to bring suit on its behalf, and perhaps also to allow the private party to keep the penalty if it prevails. ${ }^{46}$ This qui tamtype arrangement, however, would appear to come so close to replicating the barred liability to individuals that the Court would probably strike it down. ${ }^{417}$ The arrangement would stand a greater chance of passing muster if the suit were brought by private individuals in the name of the United States but the penalty were required to be turned over to the United States. This arrangement might work if the federal obligations involved had broad public impact and there existed public interest organizations willing to take on such projects. It may work, for example, in the environmental area. With respect to federal obligations that benefit discrete categories of individuals, such as the obligation not to infringe patents or copyrights or to engage in false advertising, affected individuals would seem to lack an incentive to bring an action if they cannot keep the "penalty." Perhaps if such individuals were permitted to add a "penalty-to-the-United-States" count to an action they would otherwise bring for injunctive relief, they would have an adequate incentive to do so, if only to deter future infringements. If this arrangement were found to comport with the Eleventh Amendment, the concerns raised above about states simply

444. 504 U.S. 555 (1992); see also supra note 288.

445. Justices Kennedy and Souter appear to contemplate little more than a clear statement rulc, under which Congress would be required to identify the interest it seeks to protect and the plaintiff's connection to that interest. See Lujan, 504 U.S. at 580 (Kennedy, J., concurring in part and concurring in judgment). 446. See Siegel, supra note 110.

447. See supra notes 110-11. 
ignoring their federal obligations until called to account would be further alleviated.

A scheme in which the rightholder could be compensated for past violations would obviously be preferable. It is here that our reinterpreted McKesson and such related cases as Poindexter and Bivens become relevant. As interpreted above, these cases stand for the proposition that the Supremacy Clause establishes a private damage action against state officials who violate the Constitution. I have argued elsewhere that the Supremacy Clause should be read to establish a presumption that federal statutes that impose obligations on government provide a private damage action against government officials to the individuals the statute was designed to protect. ${ }^{.+5}$ Even if this presumption were rejected, however, Congress would retain the power to make state officials personally liable for their violations of federal statutes. Current case law recognizes this power, as the Cour in Maine $v$. Thiboutor construed section 1983 to make state officials personally liable for violating statutory obligations imposed pursuant to Article I. ${ }^{450}$ It has been suggested that the Thiboutot decision is endangered after Seminole Tribe, ${ }^{\text {sit }}$ but even the dissenters in Thiboutot did not deny that Congress had the power to impose such liability; they merely argued that Congress had not done so when it passed section $1983 .{ }^{452}$

If there is a problem with the suggestion that Congress may make state officers personally liable for violating statutes that validly place obligations on states, the problem stems not so much from the Eleventh Amendment, which has long been understood not to apply to suits seeking damages from officers personally, but from the Tenth Amendment, and the New York decision in particular. For example, the Worker Adjustment and Retraining Notification Act makes "employers" liable in damages in certain circumstances, but if the employer is a corporation, the statute does not subject the corporation's officers or directors to personal liability. ${ }^{43}$ Would an amendment to that Act making state officials personally liable for violations of the Act run afoul of New York's apparent holding that Congress may impose the same obligations

448. See supra note 420 .

449. 448 U.S. 1.

450. Although the T7tiboutor case itself was aganst the state of Mane, the Coun was weil aware that its holding would make officers personally liable. See id. at 22 (Powell. 3 . dissentung) ("In practucal effect. today's decision means that state and local governments, officers, and employees now may face lazbulty whenever a person believes he has been injured by the administration of any federal-state cooperalive program, whether or not that program is related to equal or civil nghts ") (citations omitled). To the cxient that the Court held (or assumed) that section 1983 created a cause of actuon against states, $t$ is no longer good law. See Will v. Michigan Dep't of State Police, 491 U.S. 58 (1989): supra Subsccuon III.B 4

451. See Jackson, supra note 15.

452. Indeed, Justice Powell's dissent states that he "doles] not mean to imply that either $\$ 1983$ or $\$ 1988]$ must be limited strictly to claims arising under the post-Cival War Amendments." See Thuboutor. 448 U.S. at 25 n.15 (Powell, J., dissenting).

453. See 29 U.S.C. § $2101(a)(1)$ (1994) (defining "cmployer" as including terian "business enterprise[s]"); id. § 2104(a) (making employers labble to employoes in parucular curcumstances) 
on states that it imposes on private individuals, but not more? Perhaps the Court would hold that state officials are not the state for New York purposes, just as they are not the state for Eleventh Amendment purposes. This may not be likely, as the Court already defines the state more broadly for Garcia/New York purposes than it does for Eleventh Amendment purposes. ${ }^{454} \mathrm{~A}$ stronger argument is that the power to make state officials personally liable comes from the Supremacy Clause and the need to give efficacy to the statutes Congress has the power to enact. By preventing Congress from making the states themselves liable, the Eleventh Amendment makes it impossible for Congress to employ with respect to the states the same enforcement scheme it has chosen for private parties. As argued above, the Supremacy Clause establishes a right of action against state officials as the default mechanism for giving efficacy to those officials' constitutional obligations. If the Constitution permits Congress to impose additional obligations on the states, then it should be construed to authorize Congress to give efficacy to those obligations by making state officials personally liable.

But, even if I am wrong, the problem is not an insuperable one, as Congress can surely make state officials personally liable if it makes similarly situated employees and directors of private companies liable as well. If that is what it takes 'to provide a retrospective remedy for state violations, then Congress would have little reason not to do so. Where the claimant has the option of suing both the employee or director and the corporation, the deeper pocket will wind up paying the judgment. While it may be a nuisance to individual corporate employees or directors to be named as a defendant, anyone who has sufficient resources to make an appealing target is also likely to be sophisticated enough to have arranged for full indemnification (including for litigation costs). ${ }^{455}$ Indeed, Congress appears to have made corporate officers and directors personally liable for such legal violations as failure of the company to pay a minimum wage, ${ }^{456}$ yet suits naming officers personally for failure to pay the minimum wage are rare ${ }^{457}$ It appears that state officials may now be sued personally for failure to pay the minimum wage, even though the state itself may not be (at least if the immunity-from-liability interpretation is correct). ${ }^{458}$ Unlike employees of private companies, however, employees of state agencies do have an incentive to sue their bosses personally.

454. See supra note 100.

455. Such an agreement may not protect the officer if the company should declare bankruptcy, but a sophisticated officer could protect herself from this possibility by obtaining liability insurance.

456. See Fair Labor Standards Act, 29 U.S.C. \$ 203(d) (1994) (defining "employer" as including persons acting for employer); id. $\$ 216$ (b) (making employer liable for failure to pay minimum wage). See also supra note 441 (noting that government officials are liable in damages for patent infringement).

457. Telephone interview with Mary Qualiana, Labor and Employment Attorney, Washington, D.C. (Feb. 7, 1997).

458. See supra note 102 (noting cases finding FLSA's abrogation of state immunity unconstitutional). 
A possibly significant obstacle to recovery against a state official for statutory violations is "official" immunity. Under current doctrine, state officials sued in their personal capacities are entitled to an immunity that protects them from liability unless they violated "clearly established" law. ${ }^{499}$ As this standard is currently applied, the law must have been clearly established at the level of application of law to fact. ${ }^{400}$ This may pose problems for certain types of claimants. Patent holders, for example, would presumably have to show that prior authorities "clearly established" both that the patent was valid and that the defendant's conduct infringed it. But official immunity is generally regarded as subconstitutional in stature. ${ }^{461}$ If so, then presumably Congress can do away with it. This would appear to present no problems under New York as long as the same standard of liability applies to state employees as to private employees. Indeed, it may even be open to Congress to impose a form of "strict" liability on heads of agencies by enacting a law providing that the CEO of any entity that infringes a patent (defined to include the head of any state agency) shall be personally liable to the patent holder to the same extent as the company itself.

Does an official-liability regime for violations of federal law satisfy ruleof-law concerns? As noted, it is often said that the rule of law requires that there be remedies for the violation of legal rights. ${ }^{462}$ Would an officialliability regime be effective at compensating persons whose rights have been violated? An obvious concern is that officials will frequently have insufficient assets to satisfy a judgment. This is particularly likely to be the case if the legal violation involves the collection of an unconstitutional tax from a large corporation or the infringement of a valuable patent or copyright. It will also often be the case when a police officer unlawfully causes severe injury to an individual. If the injured party were in fact limited to the officer's personal assets, then chances are that she would not receive full compensation.

But the injured party will usually not be so restricted. If the law makes state officials personally liable for, say, the collection of unlawful taxes or the infringement of a patent, then states will inevitably find it necessary to offer to compensate their officials for any liability assessed against them, except perhaps where the official's violation of law was egregious, or at least to pay their officials higher salaries to enable them to obtain liability insurance. Otherwise, few would agree to work for the state. ${ }^{43}$ Virtually all states have

459. See Harlow v. Fizgerald, 457 U.S. 800.818 (1982).

460. See Anderson v. Creighton, 483 U.S. 635 (1987).

461. See, e.g., Tower v. Glover, 467 U.S. 914,923 (1984) (holding that immunity for public defenders did not exist at common law); Fallon, supra note 335, at 356: Fallon \& Meltzer, supra note 16, al 1785 But cf. Seminole Tribe v. Florida, 116 S. Ct. 1114. 1131 n.15 (1996) (suggestung that official immunty may have constitutional stature).

462. See supra text accompanying notes 2, 16.

463. See Akhil Reed Amar, Fourth Amendment First Principles. 107 HARV. L REV. 757. 812 (1994) ("Without indemnification who would agree to work for the government?"). 
statutes agreeing to reimburse their officials in specified circumstances for damages assessed against them for conduct performed within the scope of their employment. ${ }^{464}$ States also often agree by contract to reimburse their employees for damage liability, and sometimes they follow a policy of reimbursing their officials even when not required to do so by statute or contract. ${ }^{45}$ Particularly if federal statutes remove the common law immunity the official otherwise would enjoy, any rational state official would insist on some such arrangement before taking a job that exposes her to such liability. ${ }^{466}$ If the state has agreed to compensate the official, the patent holder will eventually receive his full measure of damages from the state (indirectly) without running afoul of the Eleventh Amendment. ${ }^{467}$

464. See ALA. CODE $\S 41-9-74(a)$ (1991); ARZ. REv. StaT. ANN. § 41-621 (West Supp. 1996); ARK. CODE ANN. § 21-9-203 (Michie 1996); CAL. Gov'T CODE § 825(a) (West Supp. 1996); Colo. REv. STAT. ANN. § 24-10-110(1)(b)(i) (West Supp. 1996); CoNN. GEN. STAT. ANN. § 5-141d(a) (West Supp. 1996); DEL. CODE. ANN. tit. 10, § 4002 (Michie Supp. 1994); FlA. STAT. ANN. § 111.071 (Harrison 1985); GA. CODE ANN. § 45-9-60 (1990); HAW. REV. STAT. § 26-35.5 (1995); IDAHO CODE § 6-903(b)-(c) (Michic 1990); 5 ILl. COMP. STAT. ANN. 350/2 (West 1993); IND. CODE ANN. § 34-4-16.7-1 (Michic 1986); IoWA CODE ANN. § 669.21 (West, WESTLAW through end of 1995 Reg. Sess.); KAN. STAT. ANN. \$ 75.6109 (West, WESTLAW through end of 1995 Reg. Sess.); KY. REV. STAT. ANN. \$15.753 (Banks-Baldwin, WESTLAW current through end of 1995 3d Ex. Sess.); LA. REv. STAT. ANN. § 13:5108.1 (West, WESTLAW current through all 1995 Reg. Sess. Acts); ME. REV. STAT. ANN, tit. 14, $\$ 8112$ (West, WESTLAW current through end of 1995 First Reg. Sess.); MD. CODE ANN., STATE Gov'T \$ 12-404 (Michie 1995); MASS. GEN. LAWS ANN. ch. 258, §9 (West 1988); MICH. COMP. LAWS ANN. \$ 691.1408 (West 1987); MINN. STAT. ANN. § 3.736 (West Supp. 1997); Miss. CODE ANN. $\$ 11-46-7$ (Supp. 1996); MO. ANN. STAT. § 107.170(5) (West Supp. 1996); MONT. CODE ANN. § 2-9-305 (1995); Neb. REv. STAT. \$81-8,239.05 (1996); NEV. REV. STAT. ANN. \$ 41.0349 (Michie 1996); N.H. REV. STAT. ANN. \$ 99-D:2 (1990); N.J. STAT. ANN. § 59-10-1 (West 1992); N.M. STAT. ANN. § 41-4-4 (Michic Supp. 1996); N.Y. PUB. OFF. LAW \& 17(3)(a) (McKinney 1988); N.D. CENT. CODE § 32-12.1-04 (1996); OHIO REV. CODE ANN. § 2744.07(A) (Anderson 1992); OKLA. STAT. ANN. tit. 51, § 162(A) (West Supp. 1996); OR. REV. STAT. $\$ 30.285$ (1995); R.I. GEN. LAwS § 9-31-12 (Michie Supp. 1996); S.C. CODE ANN. \$ 15-78-70 (Law Co-op. Supp. 1995); S.D. CODIFED LAws $\$ 3-19-1$ (Michie 1994); TEX. CIV. PRAC. \& REM. CODE ANN. $\S 104.002$ (West Supp. 1997); UTAH CODE ANN. \$ 63-30-36 (Michie 1993); VT. STAT. ANN. tit. 12, § 5606(a) (West Supp. 1996); VA. CODE ANN. \$ 2.1-526.8(A) (Michie 1995); WASH. REV. CODE ANN. § 4.24.490(1) (West Supp. 1997); W. VA. CODE § 29-12A-11(a)(2) (1992); WIS. STAT. ANN. \$ 895.46(1)(a) (West Supp. 1995); WYO. STAT. ANN. \& 1-39-104 (Michie 1988). The courts that have considered the question have held that the existence of a state law duty to reimburse an official does not transform a suit against the official into a suit against the state for Eleventh Amendment purposes. See HART \& WECHSLER, supra note 100 , at 1076-77.

465. See Clayton P. Glllette, Local Government Law 707-08 (1994). Additionally, "it is not uncommon for organizations of public employees, such as a peace officers' association, to make arrangements for low cost group insurance coverage against personal liability for certain kinds of torts (e.g., wrongful artest, assault and battery, etc.)." Sho SATO \& ARVo VAN ALSTYNE, STATE AND LOCAL GOVERNMENT LAW 784 (2d ed. 1977). "Careful counsel may also discover that in some jurisdictions mandatory official bonds covering certain positions may be written in terms broad enough to include tortious injuries, with liability running in favor of members of the public." Id. (citations omitted).

466. It is well-settled that a state's agreement to reimburse its officials does not transform a suit against the official into a suit against the state for purposes of the Eleventh Amendment, even though the damages will ultimately come from the state treasury. See Fowler v. Lindsey, 3 U.S. (3 Dall.) 411,412 (1799) (stating that "remote interest of the State, in making retribution to her grantees" does not deprive federal court of jurisdiction); Demery v. Kupperman, 735 F.2d 1139, 1146-48 (9th Cir. 1984) (holding that state's agreement to indemnify does not transform suit against official into suit against state for Eleventh Amendment purposes).

467. It is the practice of local governments that have agreed to compensate their officials-and probably of most states as well-to pay judgments against their officials directly to the plaintiff. Telephone interview with Benjamin L. Hall, II, former City Attorney for Houston, Texas (Feb. 13, 1997). If a state 
In the end, it may not be necessary for the patent holder even to sue the officer in court. As interpreted above, McKesson recognizes the state's freedom to substitute itself for the officer as the defendant, and certainly Congress can make it clear in the statute that the state has this option. The state would have a number of incentives to do so. First, it would greatly simplify the process for all concerned, including its officers and itself. The cost of administering an officer-liability-plus-state-reimbursement scheme is likely to be greater for the state than the cost of administering a straight state-liability regime. For example, the state will no doubt want its own lawyer to control the defense, but unless the officer is dismissed as a defendant the officer is likely to want his own lawyer as well (and this is presumably a cost that the state will ultimately have to pick up). Second, the prospect of personal liability is likely to lead risk-averse officers to steer excessively clear of the line drawn by the law, and, if so, the state will forgo an excessive amount of conduct that does not in fact violate the law. The state can remove some of this excessive deterrence by agreeing to reimburse the official or to pay her insurance, but it can go further to neutralize this problem by committing itself in advance to being the sole defendant in the case. Finally, agreeing to be substituted as the defendant may be the only way for the state to avoid a trial in federal court. As noted, the state official can be made suable in federal cour without raising Eleventh Amendment problems. The state could, consistent with McKesson, agree to be substituted as the sole defendant in a state court proceeding only, ${ }^{468}$ and if it does so, the Supreme Court can review any decision the

did not wish to be cooperative, it could force the plaintuff to seek enforcement from the offictal. and then reimburse the official for what he paid to the plaintiff. If the plantiff were forced to proceed aganst the official and part of the judgment remained unpaid because the official lacked sufficient personal resources to satisfy the entire judgment, the plaintiff should be able to recover the unpard portion of the judgrnent after the official receives reimbursement from the state of the amount paid by him to the planuff the first time. In this way, the plaintiff should eventually recover the whole judgment.

Presumably, a state would not be free to say that any amounts pasd to the official by the state as reimbursement for damages shall be exempt from attachment by the judgment creditor. A state law to that effect would arguably constitute an impermissible burden on the consututionally required remedy against state officials and thus violate the Supremacy Clause. If the excmpuon applied only to damages for violations of federal law, it would probably also amount to unconstitutuonal discnmination aganst the federal rights violated by the official. Cf. McKnetl v. St. Lous \& San Francisco Ry. 292 U.S. 230. 234 (1934) ("A state may not discriminate against rights arising under federal laws.") A broader state law nule shielding from execution any amounts traceable to money pard to the official by the state would certainly not be permissible, as most of the personal resources of state officials are presumably the proceeds of money paid to the official by the state as salary. In any event. I am not aware of any state law that purports to shield from antachment by judgment creditors amounts pand to the offictal by the state as reimbursement or salary.

468. It has long been established that states may consent to be sued only in their ow $n$ courts. See Smith v. Reeves, 178 U.S. 436 (1900). However, as McKesson established. see Mickesson Corp. 1. Disision of Alcoholic Beverages \& Tobacco, 496 U.S. 18, 30 (1990). and Semuole Tribe rearfirmed, see Seminole Tribe v. Florida, 116 S. Ct. 1114, 1131 n.14 (1996), a state's consent to be sued in is own courts also constitutes consent to the Supreme Court's review of any federal clasms resolved in such a surt. It is true that the state may not in fact be voluntarily agreeing to Supreme Coun review, but out discussion of McKesson above showed why the state does not have the option of consenung to suit in ils own cours but not to Supreme Court review: The state's consent to be sued in th cours typically replaces the nght the claimant would otherwise have had to recover against state officials, and a suit aganst state offictals could 
state court rendered. Congress could perhaps provide by statute that to avoid a suit against the official, the state must consent to being sued in the lower federal court. Such consent would avoid any Eleventh Amendment problems with the federal courts' original jurisdiction, but such a provision would remove one of the three incentives the states would have to consent. (Whether the remaining incentives suffice to meet the federal interests involved is of course a judgment for Congress to make.)

If Congress does indeed have the power to withdraw or narrow official immunity, then Congress would have the power to design an official liability scheme that should achieve roughly the same degree of compensation for victims as a government liability scheme. In particular, a statute designating agency (and company) heads as strictly liable for their agency's (or company's) violations of certain statutes is very likely to produce either an agreement between the head and the agency providing for full indemnification or a straight waiver of immunity. But this scheme achieves full compensation by successfully encouraging-some might say coercing-states to take on a liability that we are assuming Congress lacks the power to impose on them directly. The scheme seems so well-calculated to achieve Congress's goal of getting the state to pay that it may cast doubt on the conclusion that Congress indeed possesses this power. Recall that much of the support for the immunityfrom-liability interpretation comes from the authorities establishing that one of the purposes of the Eleventh Amendment is to protect state treasuries. We found the forum-allocation interpretation inconsistent with any such intent because, if the states are liable under federal law and the Supreme Court is available to enforce the liability, the states' treasuries would not in the end be protected. It might similarly be argued that if Congress has the power to place obligations on state officials that are all but certain to lead states to "consent" to take on the liability itself, then the state treasuries have not been protected either. If so, the official-liability regime seems just as inconsistent with the purpose of protecting state treasuries as the forum-allocation interpretation.

The argument is not devoid of merit, but there does seem to be a difference in kind between imposing a liability on the state directly and imposing one on an officer in the hope and expectation that the state will agree to take on the liability itself. It has long been recognized that "the purpose of allowing actions against officers is ... to find a conduit to the treasury in cases where there should be compensation and where no other device is provided"-to bring "pressure to bear in favor of a remedy [from the treasury]." ${ }^{469}$ And it is well established that success in this regard does not

be reviewed by the Court with no Eleventh Amendment problems. A consent to suit without Supreme Court review would be inadequate to protect the federal interests at stake and so is rightly regarded as ineffective to justify a withdrawal of the official's liability.

469. Jaffe, supra note 392 , at 227-28. 
imbue the official with the state's Eleventh Amendment immunity, even though the damages will in such a case come from the state treasury. ${ }^{470}$ Congress's establishment of a strict liability standard for agency heads would not in fact differ significantly from the standards the Cour itself once applied to determine federal officials' susceptibility to damage liability. ${ }^{471}$ To say such legislation unduly coerces the states' consent seems no more apt than saying that a private party coerces the states by refusing to do business with them unless they agree to waive their immunity. Perhaps all of this goes to show that the real purpose of sovereign immunity is not to protect the state treasury, that it advances instead only the state's dignitary interest in not being subjected to liability unless it has consented. But perhaps it shows instead that the immunity protects the states' treasuries only at the margins. To recognize Congress's power to impose strict liability on officials, as suggested above, may mean that the margin is getting smaller. Be that as it may, the margin would entirely disappear were we to accept the forum-allocation view. The suggested officer liability scheme is thus at least marginally more faithful to the purpose of protecting state treasuries than the forum-allocation interpretation.

At any rate, if the claimed conflict with the purpose to protect state treasuries were deemed problematic, it could be addressed by denying Congress the power to render state officials strictly liable for their agencies' statutory violations, without going further and denying Congress the power to remove the rather stringent "official" liability the Court has given them. To do the latter would contradict many years of treating this immunity as subconstitutional. ${ }^{472}$ There is, however, some intimation in Seminole Tribe that the Court may be heading in that direction. ${ }^{473}$ If it does, then Congress would be able to subject state officials to personal liability only for their violations of "clearly established" law. Congress's only option in that event would be to provide as much detail in its statutes as possible.

Where Congress has not taken special steps to increase the likelihood that officials will have obtained a commitment of full indemnification-and this will typically be the case for constitutional violations, as the majoritarian branch is unlikely to be as intent on securing compensation for violations of these countermajoritarian norms-then the chances that victims of legal violations will not be fully compensated are very real. For example, as noted, many state indemnification statutes exclude indemnification for particularly

470. See supra note 466 .

471. See, e.g., Linle v. Barreme, 6 U.S. (2 Cranch) 170, 179 (1804) (holding naval captaun luable for seizure of neutral vessel pursuant to executive order). See generally. Engdahl. supra note 42. Ann Woolhandler, Panterns of Official Accountabilin, 37 CASE W. RES. L REV. 396. 453-57 (1986-87)

472. See supra text accompanying note 461 .

473. See $116 \mathrm{~S}$. C. at 1131 n.15 ("IE]ven assuming the immunily enjoyed by state and federal officials] has no constitutional foundation, ....."). 
egregious violations of law. An official-liability regime will therefore not entirely satisfy those who insist that there must be full remediation. But, contrary to the claims of some scholars, ${ }^{474}$ neither the rule of law as an ideal, nor the Anglo-American legal tradition, demand that everyone who has received unjust or unfair treatment at the hands of government be fully compensated for his injury. Take just one uncontroversial example: An innocent person who has been accused of a crime, has been duly indicted and tried and acquitted, but whose liberty was restrained for a lengthy period of time pending completion of the trial, is not entitled to a damage remedy against the state or its officials (except perhaps in very rare circumstances). The injury suffered by innocent persons forced to defend themselves in a criminal trial, even if not confined, is of the most acute kind, and it is not alleviated by the knowledge that the evidence points to him as the perpetrator. The absence of a remedy in such circumstances cannot be reconciled with any principle of full remediation, if understood as full compensation for undeserved governmental injuries, yet our system does not offer him one, nor can it without bankrupting the state.

What the rule of law does require, and what our legal system has traditionally sought to provide, is a remedial scheme that is generally effective at producing systematic compliance with legal norms. With respect to constitutional norms, because they are countermajoritarian, and perhaps with respect to all norms applicable to government, the remedial scheme will be effective only if the power to obtain the remedies resides in private individuals. Our law of constitutional remedies has accordingly always relied on private rights of action against state officials, and it is this scheme of remedies that $I$ maintain is grounded in the Supremacy Clause. It is a happy consequence of this reliance on private rights of action that the scheme, to a considerable degree, yields compensation to those injured by violations of federal law. But the focus of the Supremacy Clause's remedial scheme, and of the rule-of-law goal, is deterrence: securing prospective compliance with law by threatening a sanction in the event of a violation. ${ }^{475}$ In truth, the maxim that for every right there must be a remedy is a less unyielding command of the rule of law than the maxim that for every law there must be a sanction. ${ }^{476}$

474. See, e.g., Amar, supra note 7, at 1485-86 ("Few propositions of law are as basic today . . as the ancient legal maxim . . . : Where there is a right, there should be a remedy.").

475. A fault-based liability regime-a regime that would deny relief, for example, to our innocent. subsequently acquitted defendant-might, to be sure, be defended on noninstrumental grounds. See John C. Jeffries, Jr., Compensation for Constitutional Torts: Reflections on the Significance of Fault, 88 MiCH. L. REV. 82, 93-101 (1989) (defending such regime on grounds of corrective justice). My claim here is that the Supremacy Clause should be regarded as the basis of a fault-based scheme of constitutional remedies for constitutional violations designed to achieve general and systematic compliance with constitutional norms.

476. Hamilton invoked the latter principle in The Federalist No. 15, and I rely on it strongly in interpreting the Supremacy Clause's declaration that the Constitution is the "law" of the land as the source of a constitutional law of remedies for violations of the Constitution. See Vázquez, supra note 80. 
That our law of constitutional remedies focuses on deterrence is evident. Official immunity, for example, is clearly geared toward that goal, the apparent theory being that you cannot deter violations of an ambiguous legal norm without overdeterring. Although the Court may apply the principle too stringently, leaving undeterred too much conduct that could and should be deterred, the principle itself seems sound from a deterrence perspective.

The Due Process Clause might perhaps have been regarded as the source of a justice-based constitutional interest in full remediation, but the Court's due process jurisprudence appears designed to advance instead the deterrence goals that I argue underlie the Supremacy Clause. This is reflected in the Court's holding that a government official's negligent conduct does not violate the Due Process Clause, even if it produces "serious injury. ${ }^{27}$ That is because the Clause protects individuals against "abusive governmental conduct." ${ }^{+78}$ This suggests that there may not be very much distance between my interpretation of the Supremacy Clause and the Court's interpretation of the Due Process Clause, and thus between my recharacterization of McKesson and the conventional one..$^{479}$

How does the official-liability regime fare from a deterrence perspective? One would expect a regime of personal liability to be more effective at deterring unlawful conduct than a regime of entity liability. ${ }^{480}$ If the liability falls on the individual officer, then that officer is more likely to be deterred than if the liability is borne by the government and thus spread among all taxpayers. If this intuition holds, then from a rule-of-law perspective, there may be a problem with agreements to indemnify, as they take the sting off the sanction. There is evidence, however, that the stigma of being sued personally

By emphasizing the deterrence goal, I do not mean to disparage the unterest in compensaung vicums of injustice. I agree with John Finnis's statement that "[i]f "effectiveness" is to be contrasted (as it need not be) with 'justice,' the coercive force of law is not merely a mather of effectiveness " Johr FLvis. Natural Law and Natural Rights 260 (1980). However. Finnis is here refemng to the injustuce that the law-abiding suffer if the law-breaker is not punished. and he 100 seems to have a form of deterrence in mind. He seems to fear that the law-abiding will stop abiding the law if they see law-breakers going unpunished. See id. at 262-63. I recognize the imponance of compensatung vicums of wrongs stmply for the noninstrumental justice of it, but in our constituuonal system this unterest clearly can be sacnficed for the common good, which includes notably the need to deter volatuons of law it is this need that clearly drives the existing remedial scheme, and properly so from a rule-of-law perspecuve

477. Davidson v. Cannon, 474 U.S. 344,347 (1986).

478. Id. at 348 .

479. The Court in Daniels v: Williams, 474 U.S. 327 (1986). saud that "like its forcbeas in the Alagna Carta," the Due Process Clause was "intended to secure the individual from the arbutrary exercise of the powers of government." Id. at 331 (quoting Hurado v. Caltforma, 110 U.S. 516.527 (1887)) The forebear in the Magna Carta was that document's reference to the "law of the land." The Coun in Murray's Lessee v. Hoboken Land \& Improvement Co., 59 U.S. (8 How.) 272 (1856). explaned that "(t)he words. "due process of law,' were undoubtedly intended to convey the same meaning as the words. "by law of the land." in Magna Charta." Id. at 276.

480. The Supreme Cour appears to share this intuition See FDIC v Meyer. 114 S CI 996. 1005 (1994) (suggesting that effectiveness of Bivens remedy lies in enabling recovery agaunst officer). Carison v. Green, 446 U.S. 14, 21 (1980) ("Because the Bivens remedy is recoverable against undividuals. it is a more effective deterrent than the [Tor Claims ACl] remedy aganst the United States ") 
leads to overdeterrence despite the broad protection officials receive from official immunity doctrines, ${ }^{481}$ and despite the widespread practice of indemnifying officers. ${ }^{482}$

Some scholars have argued that an entity liability regime is superior to an official-liability regime from the deterrence perspective. Larry Kramer and Alan Sykes conclude that the choice between government liability and officer liability is, as a matter of economic efficiency, "a matter of indifference" if the officer has sufficient resources to pay any judgment (and the transaction costs of negotiating employment contracts is low), or if the state has agreed to indemnify the official. ${ }^{484}$ They identify several inefficiencies that would be produced by an official liability rule if the officer lacked the resources to cover a judgment. Most pertinent are the inefficiencies that tend to lead to inadequate precautions against violations of law. On this score, their views about an official liability rule seem equivocal. They note that "it is conceivable that ... . employees may exercise inefficiently high levels of care due to the conjunction of risk aversion with personal liability, or to the fact that the burden of overcautious behavior falls on the general public and not on the employees." 485 They acknowledge that the government may correct this problem by offering to indemnify, but they conclude that the government might find the cost too high because it would mean forgoing the benefits of cost externalization. ${ }^{486}$ What, specifically, are these benefits? An enterprise decreases its cost of doing business by allowing the losses it causes to fall on the injured third party. This net benefit, they claim, "can be divided between the employer and the employee (in the form of higher wages) to make them both better off at the expense of the injured party whose judgment goes wholly or partially unsatisfied." ${ }^{487}$ It is not entirely clear why these possible benefits would deter an employer from agreeing to indemnify if it fears that the employee would take inefficiently high levels of care, for in such circumstances the employer would not realize the benefits of cost externalization. Those benefits would be realized only if the employee were not risk averse. There are, of course, degrees of risk aversion. With respect to any but the least risk averse employee, the appeal of an arrangement of the

481. See Nina Pillard, Taking Fiction Seriously: The Failure of Official Liability Under Bivens $39-40$ (Jan. 24, 1997) (unpublished manuscript, on file with author).

482. See Theodore Eisenberg \& Stewart Schwab, The Reality of Constitutional Tort Litigation, 72 CORNELL L. REV. 641, 686 (1987) (noting that "rampant official fear of personal liability may bc an overreaction" in light of practice of indemnification).

483. Lanty Kramer \& Alan O. Sykes, Municipal Liability Under § 1983: A Legal and Economic Analysis, 1987 SuP. CT. REV. 249, 277 n.95.

484. See id. at 272,277 n.95.

485. Id. at 280 .

486. See id.

487. Id. at 278. This is a description of one of the inefficiencies of a personal liability regime in the private sector, but the authors conclude that these concerns apply "[t]o a considerable extent" in the public sector as well. Id. 
type Kramer and Sykes fear would appear to depend significantly on her ability to avoid severe economic consequences by declaring bankruptcy. ${ }^{\text {d38 }}$ But, if the right to an effective system of constitutional remedies has its source in the Supremacy Clause, then to the extent that a system of bankruptcy-which is, after all, only statutory-undermines it, we would expect the latter to have to give way. Even if the substantive legal norm to which we want to give efficacy is statutory, and thus the right to damages as well, it is possible that Congress may have the power to deny bankruptcy protection to state officials, although this suggestion admittedly raises problems under New York of the sort we have already encountered. In any event, while such an arrangement between employer and employee might be something to apprehend in the private sector, it seems highly unlikely when the employer is a non-profit-maximizing state government and the employee is a civil servant whose salary is probably highly regulated and not individually negotiated.

Peter Schuck has argued that a government liability regime is superior from the perspective of reducing violations of law "because much official wrongdoing is ultimately rooted in organizational conditions and can only be organizationally deterred." ${ }^{\text {"89 }}$ Placing the liability on the agency rather than on the street-level officer, he argues, will be more effective at producing the sort of system-wide change that will often be necessary to reduce legal violations. This seems like a persuasive case for placing the liability on higherlevel officials instead of street-level officials, as Congress would do by making agency heads strictly liable for statutory violations, but it is not necessarily a reason for abandoning the officer-liability regime entirely. It is true that a system that makes supervisors liable for their failure to take steps to correct a system-wide problem might produce "intolerable litigation costs." $\$ 900$ Such a rule would "tempt plaintiffs to implead any number of . . . officials. Each might well want his own attomey, and the ensuing litigation over which official was the 'negligent' one would consume considerable resources."

488. See Alan O. Sykes, The Economics of Vicanous Labilnn. 93 YALE LJ. 1231. 1241-12 (1984) The Bankruptcy Code itself, however, places significant limits on the ability of an employer and employec to profit through such a scheme. Under Chapter 7, a debt is not dischargeable if it represents liabilit) for "willful and malicious injury" caused by the debtor. 11 U.S.C. \$ 523(a)(6) (1994). Under Chapter 13. such debts are not expressly made nondischargeable, but any plans proposed under this chapter must be presented in "good faith." 11 U.S.C. \$ 1325(a)(3) (1994). See BENJaAIN WEITRALB \& ALAN N. RESAICK. BANKRUPTCY LAW MANUAL, at $\$ 9.14[3]$ (3d ed. 1992). Among the factors couns have regarded as relevant in determining whether a plan is proposed in good faith are whether the debt is dischargeable under Chapter 7, and "the motivation and sincerity of the debtor in seeking Chapter 13 relief." In re Estus. 695 F.2d 311,317 (8th Cir. 1982). Thus, if the violation of federal law was willful and malictous, It would appear that the officer would have difficulty discharging the debt under etther chapter. and even if the violation was not willful and malicious, a plan that results from the type of arrangement feared by Kramer and Sykes might well fail the "good faith" requirement.

489. PETER H. SCHUCK, SUING GOVERNMENT 98 (1983).

490. Kramer \& Sykes, supra note 483, at 284.

491. Id. 
But, at the same time, the prospect of such costs should help induce the relevant officers to take the desired steps in the first place. Moreover, if a government-liability system were ultimately preferable, making supervisory officials liable would be likely to approximate it, as such officials are likely to be risk averse and, because of their positions, would be in a good position to procure indemnification agreements.

If the right of individuals to recover against state officials who violate the federal Constitution or statutes is unaffected by the Eleventh Amendment, as I suggest, then the Eleventh Amendment, interpreted to give states immunity from liability, would at bottom be a rule about vicarious liability: a rule precluding the federal government from imposing vicarious liability on the states. Government liability is always vicarious liability, as governments, like corporations, "are a legal fiction.... [They] do not act, do not make contracts, sell property, or commit torts; their agents do." ${ }^{\text {"492 }}$ It may seem odd to conclude that the Constitution imposes a rule against vicarious liability, but it is also strange to say that the rule of law requires a system of vicarious liability. Law is addressed at bottom to natural persons. Only natural persons can violate legal norms, and only natural persons can be deterred from violating legal norms. It should accordingly be possible to design a system that imposes sanctions on natural persons that would be effective at securing compliance with the law. Vicarious liability may be a convenient and perhaps less costly way to ferret out the persons responsible for a legal violation, but to say that without it the rule of law is seriously jeopardized seems an overstatement. To the extent that an official-liability regime would be less efficient or less effective, we may in the end just have to chalk those problems up to the Eleventh Amendment. But the problems, such as they are, hardly warrant the assertion that our system of constitutional remedies, or of remedies for violations by states of federal statutes, is in conflict in some fundamental way with rule-of-law values.

\section{Conclusion: The Eleventh Amendment and the Rule of LAW}

The two rule-of-law principles I described at the beginning of this Article-that for every right there must be a remedy, and that the judicial power be coextensive with the legislative-and closely related one I mentioned later-that for every law there must be a sanction-are not the only demands of the rule of law. Also important, perhaps more so, is the citizenry's, and hence the other branches', continuing respect for the judiciary as the authoritative interpreter and enforcer of the law. John Orth's scholarship on the Eleventh Amendment has suggested that the Hans interpretation of the

492. Id. at 249 . 
Amendment was driven by a fear that any judgments rendered against the states in the 1890s would have been disregarded by the states and not enforced by the Executive Branch. ${ }^{493}$ Such a judgment, while apparently in conflict with the need for a remedy for the violation of rights, was at least defensible on "higher" rule-of-law grounds. ${ }^{494}$ A blatantly disregarded Supreme Cour opinion would quite possibly have reduced the public's and the other branches' respect for the institution, to such an extent as to undermine its ability to serve the vital rule-of-law functions it serves in our government, including most importantly the function of keeping the other branches within the bounds of their constitutional authority. The blow to rule-of-law values was in any event softened in such decisions as Poindexter, which supplied the groundwork for a virtual reconciliation of the Eleventh Amendment with the rule of law.

The reasons that led the Court to interpret the Eleventh Amendment the way it did in Hans may not have much current resonance, but to throw out a century-old Supreme Court precedent, often relied upon in the interim, would raise rule-of-law problems of a different son. It is essential to the rule of law that the Court take seriously its own prior decisions, including its stated reasons for reaching those decisions. Similar concerns demand that the Cour seek to make the law as coherent as possible. It is in pan because of my belief in the importance of coherence in law for the rule of law that $I$ have taken seriously the Court's decisions in both Seminole Tribe and McKesson and have striven to retain as much of both as would be possible without altering too much settled precedent. And it is because of the importance to the rule of law of respect for precedent and of doctrinal coherence that I find ironic, to say the least, the rule-of-law-based calls for drastic doctrinal changes in this area.95 Over a century ago, the Court, in Hans and Poindexter, opted for officer liability as the means to give efficacy to the federal obligations of the states, a decision that was consonant with evidence of what the Framers intended. With one short-lived exception, the Court has adhered to that choice ever since. Respect for precedent and for coherence and continuity in the law should impel us to direct our energies to perfecting the officer-liability regime rather than to switch now to a government liability regime.

Finally, the rule of law is but a means to other ends. Among the reasons we value the rule of law is that it enables us to make decisions about how to

493. See generally ORTH, supra note 42.

494. If so, the Eleventh Amendment, as interpreted in Hans, might be regarded as one of whal Alexander Bickel has called "the passive virtues." See ALEXANDER $M$ BICKEl. THE LEAST DANGerot's Branich: THE Supreme Court at the Bar of Poltitos (1962).

495. To the extent Hans had been read as a consututonal hoiding and reliod on in the period betore Union Gas, these two rule-of-law values pulled in somewhat different direcuons for the Seminole Tribe Cour. The Court resolved the tension by treating the Union Gas precodent as vulnerable from the stan because of the lack of a rationale for the judgment commanding a majonty of the Coun. After the Seminole Tribe decision, however, both of these rule-of-law values cut docidedly against the callis by the dissenung Justices for yet another doctrinal shif. 
live our lives with a certain measure of confidence in the consequences of those decisions. ${ }^{496}$ To that end, it is sometimes better that things be settled than that they be settled "correctly." The frequent volatility of doctrine in the area of state sovereign immunity at various points in our history has seriously undermined that interest. For example, the Eleventh Amendment cases from the 1890 s involved the enforceability of state bonds. Persons who purchased the bonds in the expectation that the courts would enforce them paid a premium that they would not otherwise have paid. The States who prevailed in Hans and related cases, in turn, enjoyed a corresponding windfall. Had the law been clear from the start, of course, the buyers would have discounted the unenforceable bonds and the states would have gotten only the amount that such a risky investment would have been worth.

The state of Eleventh Amendment law in recent years has similarly been in flux. As a consequence, an Indian Tribe that was authorized to sue the State of Florida in federal court by a Congress that had been conceded that power by the Supreme Court found itself thrown out of court. Had the law been clearer, Congress could easily have achieved the desired result by authorizing a suit against the Governor. Similarly, patent holders who have been given a right to recover damages against the states find their entitlement in doubt. Had Congress known, it could have pursued other means of protecting the public interests served by granting these monopolies. I have suggested in this Article that one of these other means, the foundations of which are firmly established but the contours of which have been underexplored, is to make state officials personally liable for infringements, in the hope and expectation that states will regard it as better for all concerned to consent to bear the financial burden themselves. While there may be doctrinal or historical arguments to be made in favor of the diversity interpretation or the forum-allocation interpretation of the Eleventh Amendment, it may in the interest of certainty and predictability be preferable to abandon those projects and to begin to put in place the officer liability rules, and indemnity or insurance arrangements, that will, I think, at least approximate the rule-of-law benefits that many think can be attained only by making the states themselves liable. If I am right about the potential efficacy of an officer-liability regime at producing compliance with federal law, then which of the competing interpretations of the Eleventh Amendment the Court adopts matters less, from a rule-of-law perspective, than that the Court clearly and definitively adopt one or the other. ${ }^{497}$

496. See Richard H. Fallon, Jr., "The Rule of Law" as a Concept in Constitutional Discourse, 97 Colum. L. REV. 1, 7-8 (1997).

497. Cf. Daniel A. Farber, The Coase Theorem and the Eleventh Amendment, 13 CONST. COMMENTARY 141, 141 (1996) ("According to standard law and economics reasoning, the Eleventh Amendment may well be irrelevant."). The Court's choice, however, will of course be of enormous significance to Congress in designing an enforcement scheme, as well as to states and state officials, who must respond to Congress's choice by putting in place the necessary indemnification or insurance arrangements. 